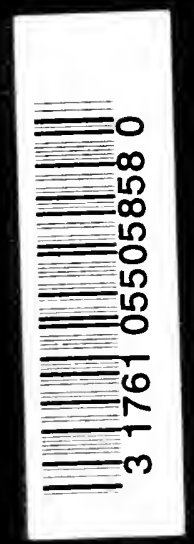







\section{Digitized by the Internet Archive in 2008 with funding from Microsoft Corporation}





\title{
CONTRACTS AND COMBINATIONS IN RESTRAINT OF TRADE
}

\author{
By \\ ALBERT M: KALES
OF THE chicago BAR
}

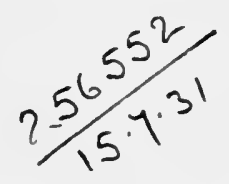

CHICAGO

CALLAGHAN AND COMPANY

1918 
enton

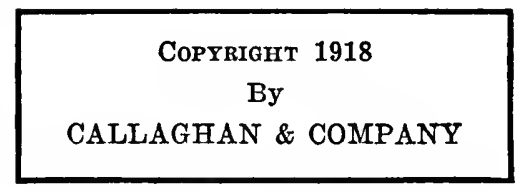




\section{PREFATORY NOTE}

In limiting the freedom of individuals in the conduct of business, or the disposal of their labor or commodities, courts ought not, and customarily do not promulgate prohibitions based on any doubtful or speculative balance of what may be, from all points of view and upon elaborate investigations of fact, most expedient and desirable. They prohibit only when a distinctive act is presented which is certainly inimical to the public interest, or which may, on a balancing of the opposing considerations, be so regarded. Where there is doubt or mere speculation as to results the tendency is to permit freedom of economic action. Yet in determining whether the distinctive act is certainly inimical to the public interest the courts must deal with economic facts and principles-especially those which are regarded as fundamental and not subject to serious controversy.

In this summary I have attempted to connect the prohibitions of the courts upon the freedom of economic action with the economic facts and principles upon which they rest. I have attempted in the text to balance economic considerations. In the notes are incorporated many quotations to indicate the economic facts and principles which the courts take cognizance of in reaching their conclusions. By this means I have sought not only to make an analysis of results but to illustrate a technique of reasoning.

I am indebted to the Harvard Law School for the opportunity of giving a course upon the subject of this volume in the year 1916-17, and of submitting the present analysis of the cases to the criticism and scrutiny of a third year class. I acknowledge a very great indebtedness to Walter T. Fisher for many valuable criticisms and suggestions. Parts of the present summary have 
appeared as articles in the Harvard Law Review and the Cornell Law Quarterly.

For convenience in making references to my casebook on Contracts and Combinations in Restraint of Trade, the pages of the casebook are referred to enclosed in square brackets thus $[-]$.

Chicago, Freb. 1, 1918.

A. M. $\mathbf{K}$ 


\title{
TABLE OF CONTENTS
}

\author{
PART 1 \\ THE COMMON LAW.
}

\section{Chapter I}

\section{CONTRACTS TO REFRAIN FROM DOING BUSINESS OR FROM ENTERING OR CARRYING ON AN OCCUPATION}

Sec. 1. The mere contract to refrain from doing business or from entering or carrying on an occupation................ 1

Sec. 2. Restrictive contracts accompanying the promisor's entry into an apprenticeship arrangement, or made upon his entry into the service of the promisee for the purpose of learning a trade or business.............................. 2.5

Sec. 3. Restrictive contracts accompanying the sale of a business, which sale, however, is not made to a competitor.

(1) Where the restriction is not broader than the business sold and is operative over a territory less than that of any state where the restriction applies.........6. 6-9

(2) Where the restriction is not broader than the business sold but extends up to or beyond the limits of any state where it is operative.................. 10

(3) Where the restriction is broader than the business sold and the business sold is not co-extensive with the boundaries of the United States.................11-14

(4) Where the business sold is co-extensive with the boundaries of the United States but the restriction is world-wide .............................. 15

Sec. 4. Restrictive contracts accompanying the sale of a business to an existing competitor where the restriction is so far limited as to be valid if the sale were not to a competitor...16, 17

Sec. 5. Restrictive contracts accompanying the combination of several business units.............................. 18

Sec. 6. Contracts not to carry on a business given by one in the business to another in the business or intending to enter it..19-22 


\section{TABLE OF CONTENTS}

\section{Chapter II}

OONTRACTS ACCOMPANYING THE SALE OF PROPERTY RESERVING THE SELLER'S BUSINESS

\section{Chapter III}

\section{Chapter IV}

CONTRACTS TO KEEP UP THE PRICE ON RESALE OR TO BUY OR USE OTHER ARTICLES IN CONNECTION

WITH THOSE SOLD

Sec. 1. Contracts to keep up the price on resale..............31-40 Sec. 2. Contracts to buy or use other articles in connection with

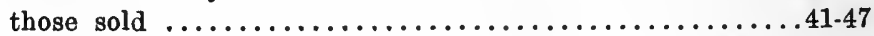

Sec. 3. Conclusion $\ldots \ldots \ldots \ldots \ldots \ldots \ldots \ldots \ldots \ldots \ldots \ldots \ldots \ldots \ldots \ldots \ldots \ldots \ldots \ldots \ldots$

\section{Chapter V}

\section{COMBINATIONS [GOOD AND BAD TRUSTS]}

Introductory $\ldots \ldots \ldots \ldots \ldots \ldots \ldots \ldots \ldots \ldots \ldots \ldots \ldots \ldots \ldots \ldots$

Sec. 1. Combinations clearly illegal....................49-52

Sec. 2. Combinations clearly legal....................53-59

Sec. 3. Combinations which have a preponderant position but no excluding purposes or practices...............60-62 The state of the authorities..................63-73

Economic effect of mere size.................. 74-91

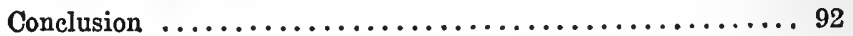

\section{Chapter VI \\ COMPETITIVE METHODS}

Introductory $\ldots \ldots \ldots \ldots \ldots \ldots \ldots \ldots \ldots \ldots \ldots \ldots \ldots . \ldots . \ldots . \ldots$

Mogul Steamship Co. v. McGregor, Gow \& Co................ 94

Scottish Co-operative Wholesale Society v. Glasgow Fleshers' Trade

Defense Association ............................. 95

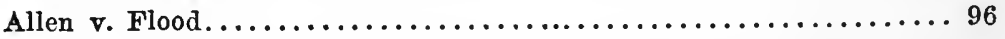

Quinn v. Leathem............................... 97

Curran v. Galen, and The National Protective Association v. Cumming 98 Berry v. Donovan............................ 99

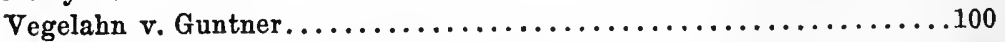

Bohn Manufacturing Company v. Hollis........................ 101

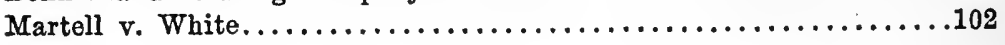


Macauley v. Tierney............................... ${ }^{88}$

Brown \& Allen v. Jacobs' Pharmacy Co..................... 104

National Fireproofing Co. v. Mason Builders' Association............ 105

Park \& Sons v. National Druggists' Association and Kingel's Phar-

macy v. Sharp \& Dohme................................

State ex rel. Durner v. Huegin.............................

Tuttle v. Buck and Dunshee v. Standard Oil Co................1078

\section{PART 2}

\section{THE SHERMAN ACT}

\section{Chapter VII}

PROBLEMS OF CONSTRUCTION

$108-112$

\section{Chapter VIII}

THE DECISIONS OF THE UNITED STATES SUPREME COURT UNDER THE SHERMAN ACT

Sec. 1. Contracts accompanying the sale of a business........113, 114

Sec. 2. Exclusive contracts of sale and purchase...............115

Sec. 3. Contracts to keep up the price on resale..............116

Sec. 4. Combinations:

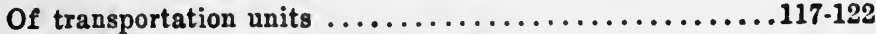

Of trading and manufacturing units..............123.130

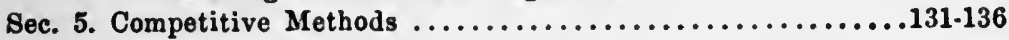

\section{Chapter IX}

THE DICTA OF THE UNITED STATES SUPREME COURT....137-144

Chapter $X$

THE CONSTITUTIONALITY AND VALIDITY OF THE SHERMAN

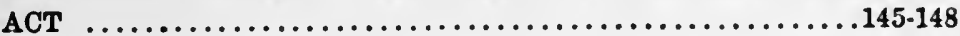

Chapter XI

WHO MAY INVOKE THE APPLICATION OF THE SHERMAN

ACT .....................................149-153

\section{PART 3}

THE FEDERAL TRADE COMMISSION LAW AND THE CLAYTON ACT

\section{Chapter XII}

THE FEDERAL TRADE COMMISSION LAW. 
TABLE OF CONTENTS

Chapter XIII

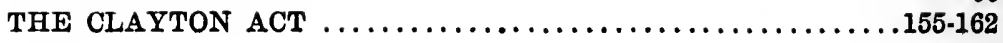

\section{PART 4}

\section{PATENTS AND COPYRIGHTS}

Chapter XIV

EFFECT OF PATENTS AND COPYRIGHTS.............162a-172 


\section{TABLE OF CASES}

SEC.

Adair v. United States........145

Addyston Pipe \& Steel Co. v. United States.........48, 123

Alger v. Thacher........... 11

Allen v. Flood.......96, 107, 132

Ames v. American Tel. \& Tel.

Co. ......................149

Anchor Electric Co. v. Hawkes $\ldots \ldots \ldots \ldots \ldots, 7,11,18,53,56$

Anderson v. Jett...........67 67

Anderson v. United States.....130

Arnot v. Pittston \& Elmira Coal

Co. ...............29, 49

Attwater v. Attwater........ 35

Badische v. Schott.......... 2

Bauer v. O'Donnell........40, 166

Bax v. Whitbread......... 81

Beard v. Dennis..........16, 53

Bell Telephone Co. v. Commonwealth ................. 165

Bement v. National Harrow Co. ..............165, 167

Berlin Machine Works v. Perry 11

Berry v. Donovan........... 99

Bigelow v. Calumet \& Hecla Mining Co.

Bishop v. American Preservers' Co. .................. 66

Bishop v. Palmer.........11, 12

Blindell v. Hagan............152

Bloom v. Richards...........148

Blount Mfg. Co. v. Yale \&

Towne Mfg. Co............168

Bobbs-Merrill Co. v. Straus..40, 166
SEc.

Bohn Mfg. Co. v. Hollis... 101, 132

Bowser v. Bliss............ 6

Boyd v. New York \& H. R. Co.. 151

Brown \& Allen v. Jacobs' Pharmacy Co. ...............104

Butcher v. Buteher ( 9 Ves. 382 ). 81

Butcher v. Butcher (1 Ves. \& B.

79) $\ldots \ldots \ldots \ldots \ldots \ldots \ldots \ldots 81$

California Steam Navigation Co. v. Wright......16, 50, 53, 55

Carroll v. Giles............ 16

Central New York Telephone \& Telegraph Co. v. Averill..... 30

Central Ohio Salt Co. v. Guthrie $\ldots \ldots \ldots \ldots \ldots \ldots \ldots, 66$

Central R. R. Co. v. Collins.... 68

Central Shade Roller Co. v. Cushman .............. 53

Chapin v. Brown Bros.......7, 63

Chappel v. Brockway......... $\ldots \ldots \ldots \ldots \ldots 16,50,53,55,57$

Chesapeake \& Potomac Tel. Co. v. Baltimore \& Ohio Tel. Co...165 Chicago Gas Light Co. v. People's Gas Light Co..... 51

Chicago, Milwaukee \& St. P. Ry. Co. v. Wabash, St. L. \& P. Ry. Co................ 51

Chicago, Milwaukee \& St. P. R.

R. v. Wiseonsin..........145

Chicago, St. L. \& N. O. R. Co.

v. Pullman Southern Car Co.. 27

Cincinnati Packet Co. v. Bay....113 Clark v. Frank..........32, 61 
SEC.

Clemons v. Meadows......... 20

Collins v. Locke........... 72

Commercial Union Tel. Co. v.

New England Tel. \& Tel. Co..165

Connolly v. Union Sewer Pipe

Co.

Coppage v. State of Kansas. ...145

Continental Securities Co. v. Interborough Rapid Transit

Co. .................151

Continental Wall Paper Co. v.

Voight \& Sons Co..........

$\ldots \ldots \ldots \ldots \ldots 29,49,115,153$

Craft v. MeConoughy........ 49

Cummings v. Union Blue Stone

Co. $\ldots \ldots \ldots \ldots \ldots \ldots \ldots 52,66$

Curran v. Galen............. 98

DeKoven v. Lake Shore \& M.

S. Ry. Co...............151

Delaware \& Atlantic Tel. \& Tel.

Co. v. Delaware............165

DeWitt Wire-Cloth Co. v. New

Jersey Wire-Cloth Co.......6 67

Diamond Match Co. v. Roeber $. .6,7,8,10,11,16,53,55,56,57$

Distilling \& Cattle Feeding Co.

v. People ...........49, 66

Doe v. Pearson............ 35

Dolph v. Troy Laundry Machin. ery Co. ............53, 58

Doty v. Martin............ 6

Dr. Miles Medical Co. v. Park

\& Sons Co....32, 40, 61, 71, 110

Duffy v. Shockey.........6, 7

Duke of Norfolk's Case....... 91

Dunbar v. American Telephone

\& Telegraph Co.........49, 151

Dunlop v. Gregory........... 6

Dunshee v. Standard Oil Co..107a

Eastern States Retail Lumber Dealers' Ass'n v. United

States ..............132, 144

Elliman Sons \& Co. v. Carrington \& Son.............32, 61

Emery v. Ohio Candle Co...... 66
SRO.

Fairbank v. Leary.......... 49

Fleitmann v. Welsbach Co.....149

Fonotipia v. Bradley......... 64

Ford v. Chicago Milk Shippers'

Ass'n .................67 67

Francisco v. Smith.......... 46

French v. Parker........... 13

Gamewell Fire-Alarm Co. v. Crane .......... $7,11,12,16$

Garst v. Charles..........32, 61

Garst v. Harris...........23, 61

Geddes v. Anaconda Copper Co..151

Gibbs v. Consolidated Gas Co.

of Baltimore..............51

Gibbs v. Smith.............. 49

Gloucester Isinglass \& Glue Co.

v. Russia Cement Co........ 53

Gompers v. Rochester......... 9

Graeff v. De Turk........... 81

Green v. Price.............. 7

Greer Mills \& Co. v. Stoller.... 152

Grenada Lumber Co. v. Missis-

sippi ...............134

Grogan v. Chaffee........32, 61

Hall's Appeal ............. 9

Harding v. American Glucose

Co. ...............66, 151

Harkinson's Appeal ......... 6

Harrison v. Lockhart......... 1

Hartley v. Cummings......... 7

Hawthorn $v$. Ulrich.......... 81

Heaton-Peninsular Button Fastener Co. v. Eureka Specialty

Co. ..................165

Henry v. A. B. Dick Co.... .41, 166

Herreshoff v. Boutineau..1, 2, 7, 10

Hilton v. Eckersley......... 91

Hitchcock v. Coker......3, 4, 7, 13

Hockett v. State............163

Hodge v. Sloan............ 23

Hoffman v. Brooks............ 66

Holbrook v. Waters........6, 7

Hooker v. Vandewater.......67

Hornby v. Close........... 72 
Sre.

Horwood v. Millar's Timber \&

Trading Co. .............62 62

Houck \& Co. v. Wright....... 27

Hubbard v. Miller.....7, 14, 16, 53

Hursen v. Gavin............ 6

India. Bagging Ass'n v. B.

Kock \& Co...............67 67

International Harvester Co. v.

Kentucky ...............147

International Harvester Co. v.

United States ............ 76

John Brothers Abergarw Brwg.

Co. v. Holmes........... 46

Jones $\nabla$. Clifford's Ex'r.....59, 65

Jones $\nabla$. North............ 53

Judd v. Harrington.........67 67

Kansas v. Colorado............148

Kellogg v. Larkin............ $\ldots \ldots .1,6,7,16,50,53,55,56,57$

Kemp v. Kemp............81

Klingel's Pharmacy v. Sharp \&

Dohme ................106

Lange $v$. Werk...........11, 14 Lawlor v. Loewe......135, 152, 157 Lewrence $v$. Kidder.........7, 11 Leslio v. Lorillard............ $\ldots .6,7,16,17,20,53,55,56,57$

Lochner v. Now York........145

Loewe v. Lewlor......135, 152, 157

Lufkin Rule Co. v. Fringeli..11, 20

Lux $v$. Haggin..............148

Lyle $\nabla$. Richards.............148

McAlister v. Howell.......... 1

MeBirney \& Johnston White Lead Co. . v. Consolidated

Lead Co. ...............66

Mzcanley $\nabla$. Tierney......103, 133

Macleay, In re...............35.

Mandeville v. Harman......... 13

Mapes v. Metcalf........16, 20, 53

Marsh v. Rnssell............. 53

Martell v. White.........102, 133
Master Stevedores' Ass'n, The

v. Walsh .............. 72

Meredith v. New Jersey Zinc \&

Iron Co. .............53, 57

Metropolitan Trust Co. v. Co-

lumbus Co. ............165

Milwaukee Masons' \& Builders'

Ass'n v. Niezerowski .......66 66

Minnesota v. Northern Securi-

ties Co. ...............150

Missouri v. Bell Telephone Co..165

Mitchel v. Reynolds...........

$\ldots \ldots \ldots \ldots \ldots \ldots 1,4,7,8,9,50$

Mogul Steamship Co. v. Mc-

Gregor, Gow \& Co....50, 94, 136

Montague v. Lowry..........131

Moore \& Handley Hardware Co.

v. Towers Hardware Co...16, 53

Morris Run Coal Co. v. Barclay

Coal Co. .............52, 66

Morse Twist-Drill \& Machine

Co. v. Morse............. 2

Motion Picture Patents Co. v.

Universal Film Mfg. Co..41, 166

Murphy v. Christian Press

Ass'n $\ldots \ldots \ldots \ldots \ldots \ldots \ldots, 46$

Nash v. United States.........147

National Bank of the Metropo-

lis v. Sprague............ 49

National Benefit Co. v. Union

Hospital Co. .............

$\ldots \ldots 6,7,8,16,20,53,55,56,57$

National Enameling \& Stamp-

ing Co. v. Haberman....... 6

National Fireproofing Co. v.

Mason Builders' Ass'n. . 105, 152

National Harrow Co. v. Hench..168

National Protectivo Ass'n v.

Cumming .............. 98

Nester v. Continental Brewing

Co. .....................66 66

Newell v. Meyendorff......... 27

New York Co. v. Hamilton Co.. 46

New York Ice Co. v. Parker .32, 61

Noreross $\nabla$. James.......... 25 
SEc.

Nordenfelt v. Maxim Nordenfelt Guns \& Ammunition Co. $\ldots \ldots \ldots \ldots \ldots \ldots, 10,15,16,53$

Northern Securities Co. v. United States......51, 118, 139

Oakdale Mfg. Co. v. Garst..... $\ldots \ldots \ldots \ldots \ldots 7,18,53,55,57$

Oliver v. Gilmore.......... 20

Ontario Salt Co. v. Merchants Salt Co. ............53, 90

Oregon Steam Navigation Co. $\nabla$. Winsor $\ldots \ldots \ldots \ldots \ldots \ldots 6,14$

Paine Lumber Co. v. Neal..... $.152,158,160$

Park \& Sons Co. v. National Druggists' Ass'n .........106

Patterson v. Kentucky........163 People v. Chicago Gas Trust

Co. .............51, 68

People v. Fisher.........72, 73

People v. Milk Exchange...... 66

People $\nabla$. North River Sugar Refining Co. ............ 76

People v. Sheldon..........66 66

Pideock v. Harrington........152

Pieree v. Fuller........... 7

Pilkington v. Scott......... 7

Pocahontas Coke Co. v. Powhatan Coal \& Coke Co...... 66

Postal Cable Telegraph Co. v. Cumberland Telephone \& Telegraph Co. .165

Queen Ins. Co. v. State of Texas $\ldots \ldots \ldots \ldots \ldots \ldots \ldots 53,64,73$

Quinn v. Leathem......... 97

Railroad v. Keary..........148

Raymond v. Leavitt........ 52

Richardson v. Buhl.........68

Richardson v. Mellish........ 91

Robinson v. Suburban Brick

Co. ..............18, 53

Rosher, In re............. 35

Rousillon v. Rousillon........ 2
Sec.

Samuels v. Oliver.......... 52

Sayre v. Louisville Union Benevolent Ass'n ........53, 73

Sayward v. Carlson...........148.

Scottish Co-operative Wholesale Society v. Glasgow Fleshers' Trade Defence Ass'n....... 95

Shawnee Compress Co. v. Anderson ............114, 151

Shrainka v. Scharringhausen ..53, 64, 65

Slaughter v. The Thacker Coal \& Coke Co.........53, 57, 58

Smith's Appeal........6, 14, 56 Snow v. Wheeler............ 72 Southern Fire Brick \& Clay Co. v. Garden City Sand Co..... 28 Southern Indiana Express Co. v. United States Express Co..152 Spencer v. Spencer.........81 Standard Co. v. Methodist Co. . 46 Standard Oil Co. v. United States .........48, 49, $50,61,65,108,120,126,140,146$ Standard Sanitary Mfg. Co. v.

United States ...........171

Stanton v. Allen........... 66 State v. Creamery Package Mfg. Co. ..............168 State v. Bell Telephone Co....165 State v. Cawood............148 State ex rel. Postal Telegraph Cable Co. v. Delaware \& Atlantic Tel. \& Tel. Co........165 State v. Huegin............107 State v. Nebraska Telephone Co. ..................165 State v. Standard Oil Co.48, 67, 68 Stines v. Dorman........... 22 Strait v. National Harrow Co..168 Straus v. American Publishers Ass'n ................169

Straus v. Victor Talking $\mathrm{Ma}$ chine Co. ........44, 71, 166 Swift v. Tyson...........148 Swift \& Co. v. United States. .124 xii 
sec.

Taylor v. Blanchard......... 11

Tezas \& Pac. Ry. Co. v. South-

ern Pac. Ry. Co........... 51

Texas Standard Oil Co. v.

Adoue ..............65, 67

Thellusson $v$. Woodford.......91

Thomas v. Cincinnati, N. O. \&

T. P. Ry. Co........... 72

Thomas v. Miles' Adm'r....11, 14

Thomsen v. Cayser...........136

Tode v. Gross............... 11

Trenton Potteries Co. v. Oliphant....6, 11, 14, 16, 55, 56, 64

Tuscaloosa Ice Mfg. Co. v. Wil.

liams $. . . \ldots \ldots \ldots . . . . .20$

Tuttle v. Buck.............107a

Union Pacific R. B. Co. v.

Frank .................151

Union Trust \& Savings Bank v. Kinloch Long-Distance Telephone Co. ............... 30

United States v. Addyston Pipe \& Steel Co............... 48

United States v. American Can Co. ...............64, 88

United States v. American Tobacco Co...........49, 126, 144

United States v. Corn Products Refining Co. ............. 49

United States v. Eastern States

Retail Lumber Dealers Ass'n.132

United States v. Eastman Kodak Co. .............49, 64

United Stutes v. International Harvester Co. ............. $\ldots \ldots \ldots \ldots .48,53,68,69,70,88$

United States v. Joint-Traffic Ass'n............51, 117, 145

United States v. Keystone Watch Case Co..........64, 88

United States v. Kissel.......125

United States v. Motion Picture Patents Co............ 49

United States v. Nelson.....53, 58

United States v. New Departure Mfg. Co...............168
SEc.

United States v. Pacific \& Arc-

tic Ry. \& Nav. Co.........129

United States v. Prince Line... 64

United States v. Quaker Oats.. 53

United States v. Reading Company .................122

United States v. Terminal R. R.

Ass'n of St. Louis..........121

United States v. Trans-Missouri

Freight Ass'n ............

..........51, 68, 113, 117, 138

United States v. Union Pacific

R. Co. ..............51, 119

United States v. United States

Steel Corporation .......64, 88

United States v. Winslow......168

United States Chemical Co. v.

Provident Chemical Co.......

$\ldots \ldots \ldots 6,7,8,16,17,53,55,56$

United States Telephone Co. v.

Central Union Co........30, 153

Urmston v. Whitelegg Bros..67, 70

Van Marter v. Babcock....... $.16,20,27,53$

Vegelahn v. Guntner.........100

Vulcan Powder Co. v. Hercules

Powder Co...........67, 168

Walsh v. Dwight........... 27

Watertown Thermometer Co. v.

Pool .................... 11

Weller v. Hersee............ 6

Western Wooden-Ware Ass'n

v. Starkey .............20

Whitney v. Slayton........6, 57

Wickens v. Evans............ $.16,20,53,55,57$

Wiider Mfg. Co. v. Corn Prod-

ucts Co. ................153

Wiley v. Baumgardner......11, 14

Williams v. Miles............148

Wood v. Whitehead Bros......

$\ldots \ldots \ldots \ldots .6,16,20,53,55,56$

Woodberry v. McClurg.......68 68

Woodruff v. Berry.......... 49 



\title{
CONTRACTS AND COMBINATIONS IN RESTRAINT OF TRADE
}

\author{
PART 1 \\ THE COMMON LAW
}

CHAPTER I

CONTRACTS TO REFRAIN FROM DOING BUSINESS OR FROM ENTERING OR CARRYING ON

AN OCCUPATION

\section{SECTION 1}

THE MERE CONTRACT TO REFRAIN FROM DOING BUSINESS, OR FROM ENTERING AND CARRYING ON AN OCCUPATION

\$1. It was long ago assumed that a contract not to engage in a given business or occupation would be void where the promisor was already engaged in it and the promisce was not and did not intend to be. ${ }^{1}$

1-Mitchel v. Reynolds, $1 \mathrm{P}$. Wms. 181 (171) [9] (numbers in square brackets throughout the notes to this volume refer to the pages of the author's "Cases on Contraets and Combinations in Restraint of Trade") (". . . for suppose (as that case scems to be) a poor weaver, having just met with a great loss, should, in a fit of passion and coneern, be exclaiming against his trade, and declare, that be would not follow it any more, etc., at which instant, some de-

Kales Sum. R. of T.-1 signing fellow should work him up to such a pitch as, for a trifling matter, to give a bond not to work it again, and afterwards, when the necessities of his family, and the cries of his ehildren, send him to the loom, should take advantage of the forfeiture, and put the bond in suit; I must own, I think this such a piece of villainy, as is hard to find a name for; and therefore cannot but approve of the indignation that judge expressed, though not his manner of expressing it."') 
The reasons alleged were: the disregard of the social interest in the freedom of individuals to enter whatever business they pleased; the mischief to the party by the loss of his livelihood and the subsistence of his family; the mischief to the public by depriving it of a useful member; and the tendency toward monopoly. The last would seem to be negligible. Today, such is the freedom and ease of transportation and of entering other occupations and businesses that the danger of the loss of livelihood and subsistence for a family is not such as to cause great concern. The same changes make it less likely, than formerly, that the public will feel the loss of the service of any of its members. $^{2}$ But the social interest in all being free to enter whatever business they please is still so far operative that the mere contract to refrain from carrying on a business or occupation will be void.

This last consideration would, it is believed, be sufficient to invalidate the contract even though the promisor had not at the

2-Herreshoff v. Boutineau, 17 R. I. 3, 6 (1890) (quotation given post $\S 7$ note 13$)$.

But see Kellogg v. Larkin, 3 Pinn. (Wis.) 123 (1851) [151] ("The loss to society of a valuable member is as great a public injury now as it ever was, and as great here as anywhere. I hope, indeed, that the market value of a human being is higher now than it was in Fngland at the beginning of the eighteenth century, when the case of Mitchel v. Reynolds was decided. The capacity of an individual to produce (using that word in its largest sense) constitutes his value to the public. That branch of industry in which a man has been educated, and to which he is accustomed, and for the abandonment of which he demands compen: sation, is supposed to be the one in which he can render the greatest profit. The value of what he produces belongs to himself. The actual product belongs immediately to him who employs him, but mediately to the state, and goes to swell the aggregate of public wealth. Therefore, the law says to each and every tradesman: You shall not, for a present sum in hand, alien your right to pursue that calling by which you can produce the most and add the most to the public wealth, and compel yourself to a life of supineness and inaction, or to labor in some department less profitable to the state. And if any man, mindful of his own gain alone, but not of the public good, will bargain with you to that effect you are held discharged from such bargain btuause of the advantage that will arise to the public from so holding." ') 
time of his promise entered any business or occupation at all, and was not contemplating doing so.

The above conclusions presuppose the fact that the business is one which the public is interested in having carried on. If the business or occupation is one which, while lawful, is regarded as contrary to the public interest, such as the liquor business, it has been held that the mere contract to refrain from entering or carrying on such a business is valid. ${ }^{3}$

\section{Section 2}

RESTRICTIVE CONTRACTS ACCOMPANYING THE PROMISOR'S ENTRY INTO AN APPRENTICESHIP ARRANGEMENT, OR MADE UPON HIS ENTRY DNTO THE SERVICE OF THE PROMISEE FOR THE PURPOSE OF LEARNING A TRADE OR BUSINESS

\$2. We have the following possible considerations against the validity of such covenants: The social interest in the freedom of individuals to enter what business they please is violated. The contract tends to deprive the promisor of his livelihood, the public of a useful member, and to eliminate competition between the promisor and the promisee. On the other side we have the desirability of permitting the teaching of apprentices or employees by masters. This involves providing the means whereby they may obtain their instruction on the best terms possible. The apprentice must purchase the instruction. Practically, the easiest way for him to do it is to give his serviees in part payment and a covenant not to compete in lieu of the balance. If the covenant not to compete is not allowed, the apprentice or employee must pay cash on the basis that the master is training a competitor. The result would be poor instruction and a price which an apprentice or employee would find difficulty in meeting. If the restriction is not broader than the business of the master, the apprentice would have a large territory in which to carry on the trade or business which he has learned, and other

3-Harrison $\nabla$. Lockhart, 25 Ind.

112 (1865); McAlister v. Howell,

42 Ind. 15 (1865). 
apprentices learning the same trade in other districts could come into the district of the master and there compete with him.

Upon a balancing of the interests, it is clear that where the restriction given by the apprentice or employee is not broader than the master's business, it is valid. ${ }^{4}$

§3. Nor is it any objection to the restriction that it is to continue for the life of the promisor, and hence may continue after the master has died or gone out of business. ${ }^{5}$ The contract is still an asset of the master's estate after he is dead or when he sells his business or takes in a partner. Where he has abandoned his business, equity would no longer give an injunction, and the damages at law would be nominal.

§4. Formerly it was said that the consideration must be good and adequate, so as to make it a proper and useful contract. ${ }^{6}$ The later view is that a legal consideration which is also of some value must be given. But apparently the court will not undertake to weigh the value of the consideration against what is given in order to determine its adequacy. ${ }^{7}$

§5. Suppose, however, that a country-wide business should exact such restrictive covenants of all employees entering the business or of all persons entering the business in any executive capacity, so that they would have no choice but to stay or change their occupation completely. Would not the balance of considerations be against supporting the validity of such arrangements? Here the loss of a livelihood might be a reality. The public might in fact be deprived of a useful member. The ten-

4-Rousillon v. Rousillon, $14 \mathrm{Ch}$. D. 351 (1880); Badische v. Schott, L. R. [1892] 3 Ch. 447; Morse Twist Drill \& Machine Co. v. Morse, 103 Mass. 73 (1869); Herreshoff $\nabla$. Boutineau, 17 R. I. 3 (1890).

5-Hitcheock v. Coker, 6 A. \& E. 438 (1837) [12].

6-Mitchel v. Reynolds, 1 P. Wms. 181 (1711) [4] ("Particular restrains are either, first, without consideration, all which are void by what sort of contract soever created. 2 H. 5; 5 Moor 115, 242; 2 Leon
210; Cro. Eliz. 872; Noy, 98; Owen, 143; 2 Keb. 377; March, 191; Show. 2 (not well reported); 2 Saund. 155.

"Or secondly, particular restraints are with consideration.

"Where a contract for restraint of trade appears to be made upon a good and adequate consideration, so as to make it a proper and useful contract, it is good." )

7-Hitcheock v. Coker, 6 A. \& E. 438 (1837) [26] and see cases cited post $\& 7$ note 12 . 
dency toward monopoly might become decisive. The hiring in such a business is not really for the purpose of training men to go out and conduct a similar business, but rather with the object of keeping them permanently. A restriction, then, upon their going into any other similar business could hardly be regarded as a part of the price for teaching them. Rather must it be looked upon as a method of hampering the employer's competitors. Hence, such wholesale restrietions would point to a monopoly purpose, both in regard to the business and with respect to securing the use of the labor of certain individuals.

\section{SECTION 3}

RESTRICTIVE CONTRACTS ACCOMPANYING THE SALE OF A BUSINESS, WHICH SALE, HOWEVER, IS NOT MADE TO A COMPETITOR

86. (1) If the restriction is not broader than the business sold and is operative over a territory less than that of any state where the restriction applies, it is valid. ${ }^{8}$ The restriction is an essential part of any complete sale of the business. The soeial interest in the freedom of individuals to sell at the best price obtainable ${ }^{9}$ balanecs any soeial interest in the freedom of individuals to enter what business they please.

8-Bowser v. Bliss, 7 Black. (Ind.) 344 (1845); National Enameling \& Stamping Co. v. Haberman, 120 Fed. 415 (1903); Holbrook $\nabla$. Waters, 9 How. Pr. (N. Y.) 335 (1854); Weller v. Hersee, 10 Hun. (N. Y.) 431 (1877); Hursen v. Gavin, 162 Ill. 377 (1896); Duffy v. Shockey, 11 Ind. 70 (1858); Whitney v. Slayton, 40 Me. 224 (1855); Doty v. Martin, 32 Mich. 462 (1875); Dunlop v. Gregory, 10 N. Y. 241 (1851); Smith's Appeal, 113 Pa. St. 579, 590 (1886); Harkinson's Appeal, 78 Pa. St. 196 (1875); Oregon Steam Navigation Co. v. Winsor, 87 U. S. 64 (20 Wall.) (1873).

9-Diamond Match Co. v. Roeber,
160 N. Y. 473 (1887) [60] ("It is clear that public policy and the interests of socicty favor the utmost freedom of contract, within the law, and require that business transactions should not be trammeled by unnecessary restrictions'); Leslie v. Lorillard, 110 N. Y. 519 (1888) [69] ("The object of government, as interpreted by the judges, was not to interfere with the free right of man to dispose of his property or of his labor.'); Wood v. Whitehead Bros. Co., 165 N. Y. 545 (1901) [76] ("In the present practically unlimited field of human enterprise there is no good reason for restricting the freedom to contract, or for fearing in- 
\$ 7. Formerly it was urged against the restriction that the seller might become a charge upon the community because he could not carry on his trade or business. ${ }^{10}$ This was at once met

jury to the public from contracts which prevent a person from carrying on a particular business."); National Benefit Co. v. Union Hospital Co., 45 Minn. 272 (1891) [96] ("A contract may be illegal on grounds of public policy because in restraint of trade, but it is of paramount public policy not lightly to interfere with freedom of contract."'); United States Chemical Co. v. Provident Chemical Co., 64 Fed. 946 (1894) [102] ("In discussing this phase of the subject, we must not lose sight of some other principles, the disregard of which would be more harmful to public interest than monopolies. The right to contract is a cardinal element of constitutional liberty, and, as such, should be jealously guarded.'); Anchor Electric Co. v. Hawkes, 171 Mass. 101, 105 (1898) ("The general principle that arrangements in restraint of trade are not favored is, however, firmly established in law, and now, as well as formerly, is given effect whenever its applieation will not interfere with the right of everybody to make reasonable contracts. Whenever one sells a business with its good will, it is for his benefit, as well as for the benefit of the purchaser, that he should be able to increase the value of that which he sells by a contract not to set up a new business in competition with the old."); Smith's Appeal, 113 Pa. St. 579, 590 (1886) ("The principle is this: Public policy requires that every man shall not be at liberty to de- prive himself of the state of his labor, skill or talent, by any contract that he enters into. On the other hand, public policy requires that when a man has, by skill or by any other means, obtained something which he wants to sell, he should be at liberty to sell it in the most advantageous way in the market; and in order to enable him to so sell it, it is necessary that he should be able to preclude himself from entering into competition with the purchaser."'); Trenton Potteries Co. v. Oliphant, 58 N. J. Eq. 507 (1899) [165] ("A tradesman, for example, who has engaged in a manufacturing business, and has purchased land, installed a plant, and acquired a trade connection and good will thereby, may sell his property and business, with its good will. It is of public interest that he shall be able to make such a sale at a fair price, and that his purchaser shall be able to obtain by his purchase that which he desired to buy. Obviously, the only practical mode of accomplishing that purpose is by the vendor's contracting for some restraint upon his acts, preventing him from engaging in the same business in competition with that which he has sold."); Kellogg v. Larkin, 3 Pinn. (Wis.) 123 (1851) [142].

10-Mitehel v. Reynolds, 1 P. Wms. 181 (1711) [7] (". . . the true reasons of the distinction upon which the judgments in these cases of voluntary restraints are founded are, first, the mischief which may 
by the requirement that the seller must have received a substantial consideration for the sale of his business. ${ }^{11}$ Recently, however, this requirement has been held to be satisfied if some consideration of value in addition to, or including, the consideration necessary to make a contract is given. The courts will not go into the adequacy of the consideration in each particular case; but will rely upon the seller obtaining, in general, the fair equivalent for the sale of his business. ${ }^{12}$ Today, however, the

arise from them, first, to the party, by the loss of his livelihood, and the subsistence of his family; secondly, to the public, by depriving it of a useful member."); Gamewell FireAlarm Co. v. Crane, 160 Mass. 50 (1893) [55] ("To exclude a person from manufacturing or selling anywhere in the United States or in the world machinery designed for certain purposes, in which that person has acquired great skill, may operate to impair his means of earning a living.'); Diamond Match Co. v. Roeber, 106 N. Y. 473 (1887) [59]; Leslie v. Lorillard, 110 N. Y. 519 (1888) [69]; Oakdale Manufacturing Co. v. Garst, 18 R. I. 484 (1894) [80]; National Benefit Co. v. Union Hospital Co., 45 Minn. 272 (1891) [96]; United States Chemical Co. v. Provident Chemical Co., 64 Fed. 946 (1894) [102].

11-Mitchel v. Reynolds, 1 P. Wms. 181 (1711) [4] ("Particular restraints are either, first, without consideration, all which are roid by what sort of contract soever created. - . Or secondly, particular restraints are with consideration. Where a contract for restraint of trade appears to be made upon a good and adequate consideration, so as to make it a proper and useful contract, it is good.")
12-Hitcheock v. Coker, 6 A. \& E., 438 (1837) [26] ("But if by adequacy of consideration more is intended, and that the court must weigh whether the consideration is equal in value to that which the party gives up or loses by the restraint under which he has placed himself, we feel ourselves bound to differ from that doctrine. A duty would thereby be imposed upon the court, in every particular case, which it has no means whatever to execute. It is impossible for the court, looking at the record, to say whether, in any particular case, the party restrained has made an im. provident bargain or not. The receiving instruction in a particular trade might be of much greater value to a man in one condition of life than in another; and the same may be observed as to other considerations. It is enough, as it appears to us, that there actually is a consideration for the bargain; and that such consideration is a legal consideration, and of some value. Such appears to be the ease in the present instance, where the defendant is retained and employed at an annual salary." ); Lawrence $\nabla$. Kidder, 10 Barb. (N. Y.) 641, 649 (1851) ("In many of the early cases the language of the courts would seem to imply that the adequacy or extent of the consideration 
fear of the seller becoming a charge upon the community has practically disappeared. If the business sold is small, the seller

had something to do with the validity of the contract. They say that a mere pecuniary consideration is not sufficient; that there must be something, although it does not appear very clearly what, added to this to support the contract. This idea, however, of the necessity of any greater or other consideration for a contract of this description, than any other, was obviously unfounded, and has been exploded by the recent cases [Hitchcock v. Coker, supra, Green v. Price, $13 \mathrm{M}$. \& W. 695 (1845)]"); Duffy v. Shockey, 11 Ind. 70, 73 (1858) ("As to the question of the adequacy of the consideration, we are inclined to view this as we would any other contract made by parties capable of contracting. They should, in the absence of fraud, be presumed to have determined that point for themselves. . . This presumption is peculiarly proper in this case, for the reason that we are left in doubt as to how much the consideration to be paid by the defendant was. In addition to the 300 dollars, he was to relieve the planitiffs from their contracts with agents-to what amount we are not informed-he was to take the marble, carved or not, remaining after the completion of the outstanding contracts of plaintiffs. The value of the marble thus disposed of is not given. He was also to buy of plaintiffs marble at fixed prices; but whether those prices were advantageous to the plaintiffs, or defendant, we are not appraised by the pleadings or evidence."); Hubbard v. Miller, 27 Mich. 15, 21 (1873) ("The fact that complainant paid no more than the cost of the articles at Grand Haven can make no difference. Where a consideration recognized by law as being valuable is paid, the law very properly allows the parties to judge for themselves of the sufficiency in value of such consideration for their contracts. We cannot, therefore, enter into the question whether the consideration was commensurate in value with the restraint imposed. See Hitchcock v. Coker, 6 A. \& E. 438 (1837); Pilkington v. Scott, 15 M. \& W. 657 (1846); Hartley v. Cummings, 5 C. B. 247 (1847). And there is no reason for holding that, without the restraint contracted for, com. plainant would have been willing to purchase for the price he gave, nor can we say that the vendors could have sold at that price without such stipulation. In fact, wo must infer that, in their opinion they could not readily have done so without it, or they would not have given it. It is clear, at all events, that they thought the sale with the stipulation an advantageous one or they would not have made it. The contract must, therefore, be held fair, reasonable and valid, unless too general and unlimited as to place, as insisted under the second objection.'") See also Holbrook v. Waters, 9 How. Pr. (N. Y.) 335 (1854); Pierce v. Fuller, 8 Mass. 222 (1811) (a consideration of one dollar deemed sufficient to support the restrictive covenant.)

In Chapin v. Brown, 83 Ia. 156 (1891) [138] it would seem that the court regarded the evidence con- 
may take the consideration and start elsewhere. If the business is so large that the restriction probably covers a wide area, the consideration paid to the seller will usually be such as to keep him from becoming a public charge. ${ }^{13}$ Where the restric-

cerning the particular transaction as failing to show any adequate con. sideration. This can hardly be supported, because the recitals of the contract itself showed plainly that the seller was parting with a losing branch of his business without having it fall into the hands of those who competed with him in his other lines of business. The considera. tion was legally sufficient to make a contract, and it was a business transaction on its face in which a consideration of value was given for the restriction.

13-Nordenfelt จ. Maxim Nordenfelt Guns \& Ammunition Co., [1894] A. C. 535 [33] (The fact that the seller had become a pauper in the particular case made no difference.); Anchor Electric Co. v. Hawkes, 171 Mass. 101, 105 (1898) ("The changes in the methods of doing business and the increased freedom of communication which have come in recent years have very materially modiffed the view to be taken of particular contracts in reference to trade. The comparative ease with which one engaged in business can turn his energies to a new occupation, if he contracts to give up his old one, makes the hardship of such a contract much less for the individual than formerly, and the commercial opportunities which open the markets of the world to the merchants of every country leave little danger to the community from an agreement of an individual to cease to work in a particular field."); Herreshoff v. Boutineau, 17 R. I. 3, 6 (1890) ("In the days of the early English cases, one who could not work at his trade could hardly work at all. The avenues to occupation wero not as open nor as numerous as now, and one rarely got out of the path he started in. Contracting not to follow one's trade was about the same as contracting to be idle, or, to go abroad for employment. But this is not 80 now. It is an every-day occurrence to see men busy and prosperous in other pursuits than those to which they were trained in youth; as well as to see them chango places and occupations without depriving themselves of the means of livelihood, or the state of the benefit of their industry. It would, therefore, be absurd, in the light of this common experience, now to say that a man shuts him. self up to idleuess or to expatriation, and thus injures the public, when he agrees, for a sufficient consideration, not to follow some one calling within the limits of a particular state. There is no expatriation in moving from one state to another; and from such removals a state would be likely to gain as many as it would lose."); Kellogg v. Larkin, 3 Pinn. (Wis.) 123 (1851) [149] ("The opportunities for employment are so abundant, and the demand for labor on all sides is so pressing and urgent and the supply so limited, that I much question, were we to consider the subject as 
tion is given by a corporation the fear that the promisor will become a public charge has no place. ${ }^{14}$

\$ 8. Another ground formerly expressed for holding invalid these restrictive covenants was that they might leave a given community unserved by anyone capable of carrying on a given business. ${ }^{15}$ This may have been an important consideration in the case of a business confined to a small territory at a time when others could not mobilize readily at a given point. It is out of place today, when the ease and freedom of transportation are such that if one man goes out of business in a given locality, there is little need to fear that the public will suffer by reason of the failure of anyone to serve it. ${ }^{16}$ Besides, when a business is sold

res integra, if we should feel authorized to hold that a man had endangered his own livelihood and the subsistence of his family, by an agreement which merely excluded him from exercising the trade of a blacksmith or a shoemaker, leaving all the other departments of mechanical, agricultural and commercial industry open to him."')

14-United States Chemical Co. v. Provident Chemical Co., 64 Fed. 946 (1894) [102] ("Among the potent reasons first assigned against such contracts was that the person restrained by thus surrendering his chosen occupation-one for which he has been especially prepared might become a public eharge, and the public be injured in being deprived of his personal skill in the avocation to which be had been brought up. Such reasons eannot be applied to artificial persons without absurdity.' ')

15-Mitchel v. Reynolds, 1 P. Wms. 181 (1711) [7] ante $\$ 7$ note 10.

16-Diamond Match Co. v. Roeber, 106 N. Y. 473 (1887) [59] (" He [Parker, C. J., in Mitchel v. Reynolds] refers to other reasons, viz., the mischief which may arise (1) to the party by the loss by the obligor of his livelihood and the subsistence of his family, and (2) to the public by depriving it of a useful member, and by enabling corporations to gain control of the trade of the kingdom. It is quite obvious that some of these reasons are much less forcible now than when Mitchel v. Reynolds was decided. Steam and electricity have for the purposes of trade and commerce almost annihilated distance, and the whole world is now a mart for the distribution of the products of industry. The great diffusion of wealth, and the restless activity of mankind striving to better their condition, have greatly enlarged the field of human enterprise, and created a vast number of new industries, which give scope to ingenuity and employment for eapital and labor.'); National Benefit Co. v. Union Hospital Co., 45 Minn 272 (1891) [96] ("Moreover, as cheaper and more rapid facilities for travel and transportation gradually changed the manner of doing business, so as to enable parties to conduct it over a vastly greater territory than formerly, the 
by one to another the public is substantially as well off as it was before.

89. The tendency to monopoly by the elimination of competition is, in this class of cases, the slightest. No existing competition has been eliminated. One man has taken another's place. It is doubtful and entirely speculative whether the buyer would have competed if he could not have purchased. About all that can be said is that there is less probability that the purchaser would have competed if he could not have bought, than that the seller would compete if he had not entered into a restrictive covenant. ${ }^{17}$

\$10. (2) If the restriction is not broader than the business sold but extends up to, or beyond, the limits of any state where it is operative, it should still be held valid. The rational test is the extent of the business sold and not the boundaries of some political subdivision of the country. This is the view of the more recent cases, where the restriction has been held valid even when the sale was to a competitor. ${ }^{18}$ The argument that such restrictions tend to force the promisor to leave the state is answered by the fact that this does not cause him to leave his country, and that what is lost by one man leaving the state is gained by others coming into the state. ${ }^{19}$ The older decisions, for a time at least, appear to have made an arbitrary rule that a restrietion which operated throughout a state was void even though not broader than the business sold. ${ }^{20}$

courts were necessarily compelled to readjust the test or standard of tho reasonableness of restrictions as to place.")

17-A restrictive covenant may be found to be expressed by interpretation from the sale of a busi. ness and good will, in which case the covenantor cannot hold himself out as carrying on his former business at a new address: Hall's Appeal, 60 Pa. St. 458 (1869).

The assignment by two out of three covenantees to the third of the business protected by the covenant, operates as an assignment of the covenant to the third, and he may release it to the covenantor: Gompers v. Rochester, $56 \mathrm{~Pa}$. St. 194 (1867).

18-Nordenfelt v. Maxim Nordenfelt Guns Co. [1894] A. C. 535 [33]; Diamond Match Co. v. Roeber, 106 N. Y. 473 (1887) [55].

19-Herreshoff $\nabla$. Boutineau, 17 R. I. 3, 6 (1890) ("There is no expatriation in moving from one State to another; and from such removals a State would be likely to gain as many as it would lose.") 20-Taylor v. Blanchard, 13 Allen (Mass.) 370 (1866); Lufkin 
§11. (3) If the restriction is broader than the business sold and the business sold is not coextensive with the boundaries of the United States, it is void.21 The seller is doing more than sell what he has. He is selling a business in which he might engage in the future. The public policy therefore in favor of his being permitted to sell what he has, freely and at the best price, is not applicable. The social interest in freedom of individuals to enter what business they please is not balanced by any social interest in freedom to sell at the best price obtainable. It may be that today there is little danger that the seller will become a charge on the community ${ }^{22}$ but that the public may be deprived

Rule Co. v. Fringeli, 57 Oh. St. 596 (1898) (Both of these cases involve sales to competitors, but no suggestion has been made that the rule of these cases was limited to the case of a sale to a competitor.); Anchor Electric Co. v. Hawkes, 171 Mass. 101 (1898) where the restriction accompanied a combination of competitors, seems contra to Taylor v. Blanchard supra.

21-Trenton Potteries Co. v. Oliphant, 58 N. J. Eq. 507 (1899) [161]; Bishop v. Palmer, 146 Mass. 469 (1888) [45]; Berlin Machine Works v. Perry, 71 Wis. 495 (1888); Alger v. Thacher, 19 Pick. (Mass.) 51 (1837); Lawrence v. Kidder, 10 Barb. (N. Y.) 641 (1851); Lange v. Werk, 2 Oh. St. 519 (1853); Thomas v. Miles, 3 Oh. St. 274 (1854) ; Wiley v. Baumgardner, 97 Ind. 66 (1884).

$A$ fortiori, it is illegal if in addition to the restriction being broader than the business sold, the sale is to a competitor: Gamewell FireAlarm Co. v. Crane, 160 Mass. 50 (1893) [50] (Sale of one out of fifteen competitors in the United States, to another.)

In some cases the courts have not been careful to determine whether the restriction as to territory was broader than the actual extent of the seller's business or not: Diamond Mateh Co. v. Roeber, $106 \mathrm{~N}$. Y. 473 (1887) [55]; Gamewell Fire-Alarm Co. v. Crane, 160 Mass. 50 (1893) [54].

In Tode v. Gross, 127 N. Y. 480 (1891) where the business sold was dependent upon a secret process, which was also sold, no inquiry seems to have been made as to whether the covenant (which was unlimited) was broader than the business sold.

But in Watertown Thermometer Co. v. Pool, 51 Hun. (N. Y.) 157 (1889) the court seems to have sustained a restrictive covenant which was broader than the business sold, going upon the reasonableness of the advantage to the vendee.

22-But see Gamewell FireAlarm Co. v. Crane, 160 Mass. 50 (1893) [55] ("To exclude a person from manufacturing or selling anywhere in the United States or in the world machinery designed for certain purposes, in which that person has acquired great skill, may operate to impair his means of earning a living."') 
of the benefit of his entering the business, and that a possible competitor may be eliminated, constitute an appreciable danger. ${ }^{23}$ It has even been suggested that the fact that the restriction is broader than the business sold gives rise to the inference that it is exacted for the actual purpose of monopoly, ${ }^{24}$ but this seems hardly so today.

\$12. The restriction may be broader than the business sold, because it relates to a territorial area larger than that in which the business was carried on,25 or because it concerns a related business which was not not actually carried on by the seller. ${ }^{26}$

813. When a professional man sells his practice and covenants not to carry it on in the place in question for the remainder of his life, it has been argued that the restriction is broader than the necessities of the case require, since it would still be in operation if the buycr abandoned practice or died in the lifetime of the seller. ${ }^{27}$ The reply is that just as the seller has sold his practice to the buyer, so the buyer may again sell his practice to another buyer or take in a partner. ${ }^{28}$ Even if the first buyer

23-Bishop v. Palmer, 146 Mass. 469 (1888) [48] ("Two principal grounds on which such contracts are held to be roid are that they tend to deprive the public of the services of men in the employments and capacities in which they may be most useful, and that they exposo the public to the evils of monopoly."); Gamewell Fire-Alarm Co. v. Crane, 160 Mass. 50 (1893) [55] ("The prineipal object of the stipulation was, we think, to prevent the manufacture or sale by the defendant of any instruments which would serve the same purpose as those made and sold by the plaintiff, and thus to enable the plaintiff more completely to control the market." )

24-Mitchel v. Reynolds, 1 P. Wms. 181 (1711) [9] ("It shows why a contract not to trade in any part of England, though with consideration, is void, for there is something more than a presumption against it, because it can never be useful to any man to restrain another from trading in all places, though it may be, to restrain him from trading in some, unless he intends a monopoly, which is a crime.")

25-Bishop จ. Palmer, 146 Mass. 469 (1888) [45].

26-Gamewell Fire-Alarm Co. v. Crane, 160 Mass. 50 (1893) [50] (The seller, who was a manufacturer, covenanted not to carry on the business of manufacturing or selling, and not to enter into competition with the buyer either directly or indirectly.)

27-Per Denman, C. J., in Hitchcock v. Coker, 6 A. \& E. 438 (1837) [16]; Per Van Fleet, V. C., in Mandeville v. Harman, 42 N. J. Eq. 185, 193 (1886) [32, n. 9].

28-French v. Parker, 16 R. I. 
dies in the lifetime of the seller, the fact that he had a practice protected from the seller's competition may make his practice an asset which his administrator can sell. ${ }^{29}$ Furthermore, the buyer purchased the seller's practice, which means the practice which the seller would have during his life. It would hamper such transactions too much if the covenant had to be worded so as to take care of all the contingencies under which the restriction might cease to be of value to the buyer.

\$14. Covenants which seem to be broader than the seller's business may be divisible, so that the separable part which is not broader than the seller's business may be enforced. ${ }^{\mathbf{3 0}}$

\$15. (4) If the business sold is coextensive with the boundaries of the United States, but the restriction is world-wide, is it valid? It has been said that where the restriction related to the territorial area of a foreign country, that fact could not be

219 (1888) [29] ("If the complainant here wished to retire from his practice, and sell it, he could probably sell it for more if he would secure the purchaser from competition with the defendant forever than he could if he could only secure him from such competition during his own life. So, if he wished to take in a partner, he could, for the same reason, make better terms with him."')

29-Hitchcock v. Coker, 6 A. \& E. 438 (1837) [24].

30-Trenton Potteries Co. v. Oliphant, 58 N. J. Eq. 507 (1899) [161] (Restriction applied "within any state in the United States of America, or within the District of Columbia, except in the State of Nevada and the Territory of Arizona," and was held applicable to the area of each State disjunctively described, and enforced in the State where the covenantor's business was carried on); Smith's Appeal, $113 \mathrm{~Pa}$. St. 579, 590 (1886) (restriction "in the County of Le- high or elsewhere"); Thomas v. Miles, 3 Oh. St. 274 (1854) (restriction in "said city or elsewhere"); Lange v. Werk, 2 Oh. St. 519 (1853) (restriction in "the County of Hamilton, in the State of Ohio, or any other place in the United States." Held valid as to Hamilton County); Wiley v. Baumgardner, 97 Ind. 66 (1884).

In Oregon Steam Navigation Co. v. Winsor, 87 U. S. 64 (1873), the restriction was held divisible as to the time it was to be operative. It was enforced during the time it could properly be operative. Sed quaere ad hoc.

In Hubbard v. Miller, 27 Mich. 15 (1873) a covenant not to carry on a certain business was, without any express limitation as to territory, construed as forbidding the carrying on of the business only at the eity where the business sold had been carried on, and such territory round about as the business would naturally and reasonably be carried on in. 
an argument against the validity of the covenant. ${ }^{31}$ This may be doubted; for it is now apparent that restrictions upon doing business in a foreign country may have a very unfortunate effect upon the public interest in the domestic jurisdiction- especially where the covenantee is engaged in a rival business in the foreign country as well as in the domestic jurisdiction.

\section{Section 4}

RESTRICTIVE CONTRACTS ACCOMPANYING THE SALE OF A BUSINESS TO AN EXISTING COMPETITOR, WHERE THE RESTRICTION IS SO FAR LIMITED AS TO BE VALID IF THE SALE WERE NOT TO A COMPETTTOR

\$16. If the sale be illegal ${ }^{32}$ then the restriction certainly is. But if the sale taken by itself be legal, the courts have made no distinction, so far as the legality of the restriction is concerned, between the case where the sale is to be a competitor and where it is not. Accordingly, the restrictive covenant and the sale to a competitor have been sustained both where the title to tangible assets used in the business passed, ${ }^{33}$ and also where

31-Nordenfelt v. Maxim Nordenfelt Guns Co. [1894] A. C. 535 [44] ("The appellant appeared willing to concede that it might be good if limited to the United King. dom; hut he contended that it ought not to be world-wide in its operation. I think that in laying down the rule that a covenant in restraint of trade unlimited in regard to space was bad, the courts had reference only to this country. They would, in my opinion, in the days when the rule was adopted, have scouted the notion that if for the protection of the rendees of a business in this country it were necessary to obtain a restrictive covenant embracing foreign countries, that covenant would be bad.
They certainly would not have regarded it as against public poliey to prevent the person whose business had been purchased and was being carried on here from setting up or assisting rival businesses in other countries; and for my own part I see nothing injurious to the public interests of this country in upholding such a covenant.' )

$32-\mathrm{As}$ to the prineiples governing the validity of the sale see post 8848.92 which deal with combinations.

33-Nordenfelt v. Maxim Nordenfelt Guns Co., [1894] A. C. 535 [33]; Diamond Match Co. v. Roeber, 106 N. Y. 473 (1837) [55]; United States Chemical Co. v. Provident Chemical Co., 64 Fed. 
there were no such assets, and the only way in which the business could be sold was for the seller to agree not to carry it on. ${ }^{34}$ Where part of a business has been sold to a competitor by merely covenanting not to carry on the part specified, the sale and the restriction have been sustained. ${ }^{35}$

$\$ 17$. In some cases there were special elements which furnished arguments in favor of the validity of the sale and the restriction. Thus where it appeared that the competitor who sold out had recently gone into the business for the purpose of engaging in a cut-throat competition and being bought off, there was presented an actual case of excessive competition, and the buyer was in the position of endeavoring to protect his legitimate and established business from the seller's unconscionable conduct. ${ }^{36}$ So where it appeared that the seller was making

946 (1894) [98]; Trenton Potteries Co. v. Oliphant, 58 N. J. Eq. 507 (1899) [161]; Kellogg v. Larkin, 3 Pinu. (Wis.) 123 (1851); Chappel v. Brockway, 21 Wend. (N. Y.) 157 (1839); Van Marter v. Babcock, 23 Barb. (N. Y.) 633 (1857); Moore \& Handley Hardware Co. v. Towers Hardware Co., 87 Ala. 206 (1888); Beard v. Dennis, 6 Ind. 200 (1855) ; California Steam Navigation Co. $\nabla$. Wright, 6 Cal. 258 (1856); Hubbard v. Miller, 27 Mich. 15 (1873).

But see, semble, contra: Gamewell Fire-Alarm Co. v. Crane, 160 Mass. 50 (1893) [50]; Carrol v. Giles, 30 S. C. 412 (1888).

34-Leslie v. Lorillard, $110 \mathrm{~N}$. Y. 519 (1888) [65]; Wood v. Whitehead Bros. Co., 165 N. Y. 545 (1901) [72]; Wickens v. Evans, 3 Y. \& J. 318 (1829) [84]; National Benefit Co. v. Union Hospital Co., 45 Minn. 272 (1891) [94]; Mapes v. Metealf, 10 N. D. 601 (1901).

35-Leslie v. Lorillard, $110 \mathrm{~N}$. Y. 519 (1888) [65]; Wickens v. Evans, 3 Y. \& J. 318 [84]; National
Benefit Co. v. Union Hospital Co., 45 Minn. 272 (1891) [94].

36-Leslie v. Lorillard, $110 \mathrm{~N}$. Y. 519 (1888) [65]; United States Chemical Co. v. Provident Chemical Co., 64 Fed. 946 (1894) [98], scmble, (The court noted that the seller sold only part of its tartar business, so that it had been in a particularly advantageous position to cut prices in that part of the business sold, while making a profit on the other part, thus practicing the scheme of local price cutting to put the buyer out of business. The court speaks of the seller as being a dangerous and aggressive rival. The court said: "The plaintiff was making inroads upon the defendant's business, and greatly cutting the prices of its sole manufactured product, while with the plaintiff this product was but a single feature of its manufacturing plant. The defendant bad a perfect right to buy off the competition of a dangerous, powerful and aggressive rival. The law of self-defense 
tartar of both rock and bone, and that both were of equal utility, and the seller parted with his bone tartar business only and kept his rock tartar business, the court noted that the public purchasing tartar still had competition as to prices between rock tartar and bone tartar. ${ }^{37}$

\section{SECTION 5}

RESTRICTIVE CONTRACTS ACCOMPANYING THE COMBINATION OF SEVERAL BUSINESS UNITS

818. If the combination be illegal 38 then the restriction certainly is. But if the combination taken by itself be legal, the courts appear to have made no distinction, so far as the validity of the restriction is concerned, between the case of a sale and a combination. ${ }^{39}$

The principal question which arises is whether the test of the validity of the restriction is the extent of the business sold or of the businesses combined. Is the restriction void only if it is broader than the business sold or only if it is broader than the businesses combined? The latter position has been sustained. ${ }^{40}$ The situation is like that of an incoming partner, who devotes himself to the common business of all the partners, and may properly be restricted so that he cannot carry on the same business in competition with the partnership.

and protection applies to one's business as well as to his person."') 37-United States Chemical Co. v. Provident Chemical Co., 64 Fed. 946 (1894) [98].

38-For the principles applicable in determining the validity of combinations see post 88 48.92.

39-Oakdale Mfg. Co. จ. Garst, 18 R. I. 484 (1894) [78]; Anchor Electric Co. v. Hawkes, 171 Mass. 101 (1898); Robinson v. Suburban Brick Co., 127 Fed. 804 (1904). 40-Oakdale Manufacturing Co. v. Garst, 18 R. I. 484 (1894) [84] ("The circumstances show that it [the restrictive covenant] was not unreasonable. The parties contem. plated an extensive business, with a special effort to develop an export trade. No limitation of foreign countries could be made in advance, for the company was to seek its markets. In this country it might need to set branches in different parts for the sale or manufacture or exportation of its products."); Anehor Electric Co. v. Hawkes, 171 Mass. 101 (1898). But see Central Ohio Salt Co. v. Guthrie, 35 Oh. St. 666 (1880) [690].

Kales Sum. R. of T. -2 


\section{Section 6}

CONTRACTS NOT TO CARRY ON A BUSINESS, GIVEN BY ONE IN THE BUSINESS TO ANOTHER IN THE BUSINESS OR INTENDING TO ENTER IT

\$19. It has already been assumed that a contract to refrain from doing business is void when the promisor is already engaged in the business and the promisee is not entering the business and not a competitor. ${ }^{41}$ On the other hand, some contracts not to carry on a business are valid when they are secured to enable the promisee to enter the business on more advantageous terms. A common case of this sort is where a professional man, having an established practice, covenants with one intending to practice in the same place that he will not longer carry on his profession there. Here the only sale of the covenantor's business is contained in the restrictive covenant not to carry it on. Its validity, however, is beyond question. Suppose, however, that the promisee and promisor are already in the business and competing, is the covenant by one to the other to cease business valid?

\$20. Where the business is carried on principally with a plant and property which cannot readily be converted to any other use and will in all probability lie entirely idle during a period provided by the covenant, the restriction is regularly held to be illegal. ${ }^{42}$ The moment, however, the restrictive covenant is to take a steamboat off a certain run (which does not in the least involve keeping it idle but only transferring it to another service) it has

\section{1-Ante $\S 1$.}

42-Tuscaloosa Ice Mfg. Co. v. Williams, 127 Ala. 110 (1899) [176]; Clemons v. Meadows, 123 Ky. 178 (1906) [185]; (There was in these two eases the added fact that a demand existed for the full product of the plants shut down); Western Woodenware Assn. v. Starkey, 84 Mich. 76 (1890) [189] (Here it made no difference that some of the property used in the business, such as tools and equip- ment, was sold). See also Oliver v. Gilmore, 52 Fed. 562 (1892) (Here it made no difference that the promisor had given a lease to the promisee for the term of the restriction).

In Lufkin Rule Co. v. Fringeli, 57 Oh. St. 596 (1898) it is suggested that even a sale with a restriction on the seller may be invalid where it is in reality an attempt to purchase another out of business. Sed quaere ad hoc. 
been sustained. ${ }^{43}$ So where competitors agreed to cease competing by dividing the territory where their selling force operated and reciprocally covenanting not to do business in the specified territory of each other, the covenants have been sustained.44 So where the business was conducted without any plant at all, the promise to cease business and turn over all orders to the competing promisee was held to be valid. ${ }^{45}$

\$21. In looking over these results one is forced to the conclusion that the mere covenant with the competitor not to carry on a given business is specially objectionable where it involves the shutting down and standing idle of a valuable plant, rendering the property useless for the time being. A contract operating in this way presents a distinctive feature which must be considered in balancing the considerations for and against its validity. This distinctive feature is decisive against the legality of the restriction even though the latter be regarded as a method of selling the business of the covenantor.

\$22. It may be urged that the covenantee could lave purchased the property and then shut up the plant and yet the restriction by the seller must have been held valid. The answer to this is that the actual purchase of the plant and property would in most cases be a guaranty that the plant would not be shut down unless there had in fact been excessive competitionin which case the shutting down would be justified. Furthermore,

43-Leslie v. Lorillard, $110 \mathrm{~N}$. Y. 519 (1888) [65] (In this case there were the additional facts in support of the covenant that competition was excessive and was entered into by the covenantor-a newcomer in the business-for the purpose of compelling the promisee - the established line-to buy him off).

44-Wickens v. Evans, 3 Y. \& J. 318 (1829) [84]; National Benefit Co. v. Union Hospital Co., 45 Minn. 272 (1891) [94].

Similarly, where the covenantor and covenantee each engaged in the manufacture of peppermint oil and the corenantor was also engaged in raising peppermint roots, there was no objection to a division of the business, so that the covenantor, as part of the sale of his roots corenanted not to do any manufacturing for a period of time: Van Marter v. Babcock, 23 Barb. (N. Y.) 633 (1857).

45-Wood v. Whitehead Bros. Co., 165 N. Y. 545 (1901) [72]. In Mapes v. Metcalf, 10 N. D. 601 (1901) where the promisor was a printer and using a plant in his business, but where the plant was not sold, the restriction was, nevertheless, bustained. 
a plant which is simply shut down for a specified number of years must (if the contract be valid) remain shut no matter what the business conditions may be. On the other hand, a plant and property which are purchased outright and shut down may and undoubtedly would be opened by the owner as soon as business conditions warranted that step. These considerations are sufficient to justify the courts in making a distinction between the actual sale of the plant and the shutting down of the plant without such sale. ${ }^{46}$

46-In Stines v. Dorman, 25 Oh. St. 580 (1874), D purchased of $B$ a hotel property. $D$ also sold to $B$ a hotel property and $B$ cove. nanted not to use the premises so purchased for hotel purposes whilo the property which $\mathrm{D}$ purchased from $B$ was so used. The restriction was held valid. Suppose, however, it had appeared that this was a mere subterfuge to secure in effect a covenant by $B$ to shut down his hotel property and go out of the hotel business while still retaining a property useful for hotel purposes? Perhaps the restriction might still have been sustained because it was probable that under it $B$ 's property would not remain entirely useless but would be put to some other useful purpose. 


\section{CHAPTER II}

\section{CONTRACTS ACCOMPANYING THE SALE OF PROPERTY RESERVING THE SELLER'S BUSINESS}

823. In the preceding chapter the principal consideration which supported a covenant, operating in some degree to restrain trade and to produce monopoly, was that in favor of the free alienation of a business on the best terms possible. There are other considerations just as potent to justify similar restrictions. For instance, the person carrying on a business upon land is entitled to the same freedom of action in selling the land and retaining his business that he has to sell the business with or without the land. Unless the scller who desires to sell his land and retain his business can exact from the buyer a covenant not to use the land sold to carry on the business of the seller, the seller mast keep his property or run the risk in selling it that the purchaser will in fact acquire some of the business which the seller did not intend to part with and was not obliged to part with. Where, therefore, the seller who carried on a business of selling sand from his premises sold part of the land with a covenant that the purchaser should not sell any sand from the land purchased, the covenant was valid. 1 The restriction was not broader than the protection of the sellcr required.

\$24. If it be urged that the covenant was for an indefinite period and could be enforced in equity against all purchasers of the land and long after the seller had exhausted all the sand from his land, or gone out of business, the answer is that such changed conditions would cause a court to refuse specific performance and the damages would be nominal.

825. In Norcross $\nabla$. James ${ }^{2}$ the injunction against the grantee of the buyer with notice was refused because the court declined to give specific performance against the grantee of the

1-Hodge v. Sloan, 107 N. Y. 2-140 Mass. 188 (1885). 244 (1887) [215]. 
buyer unless the covenant were such that the benefit of it would run at common law. The rule adopted as to the running of the benefit at common law was that, to run, the covenant must be one to do, or refrain from doing, scmething physically on the covenantor's own land for the physical benefit of related land of the covenantee. Hodge v. Sloan only differs from Norcross v. James in holding that equity will give specific performance against the grantee of the buyer with notice when the covenant is to refrain from doing something physically on the covenantor's land for the financial (as distinguished from physical) benefit of the related land of the covenantee. 


\section{CHAPTER III}

\section{EXCLUSIVE CONTRACTS OF SALE AND PURCHASE}

\$26. Exclusive contracts of sale and purchase between business units are in reality a method of combination. If $\mathbf{A}$ agrees to sell and B to buy A's product exclusively in a given territory, $A$ and $B$ have really combined for the purpose of doing business in $A$ 's product in that territory. Competition between $B$ and others in dealing with A's commodity in the particular territory is eliminated just as if B had become a part of A's business by merger and organization as a selling department or agent. The legality of such exclusive arrangements really depend upon the principles which govern the validity of combinations by merger or purchase. These are set out hereafter. ${ }^{1}$ But for the sake of dealing with exclusive contracts by themselves, the application of those principles will here be made to such contracts.

\$27. If $A$ and $B$ are not competitors, and the exclusive contract between them does not result in a combination which occupies a preponderant position in the business it is legal. Such is the case where a producer or wholesaler who is merely one unit among many competitors makes exclusive selling or purchasing arrangements with territorial distributors or retailers of his product. ${ }^{2}$ Even where B was a railroad and agreed to run the sleeping cars of a single company exclusively for 15 years, the contract was valid. ${ }^{3}$ Looked at as an isolated transaction, the railroad was a legal organization and no consideration overcame the public interest in its freedom to contract for facilities. The fact that the exclusive contract is made with a competitor should be no more offensive than any other union of competitors. If the

1-Post \$ \& 48-92.

2-Newell v. Meyendorff, 9 Mont. 254 (1890) [221]. See also Houck \& Co. v. Wright, 77 Miss. 476 (1899); Walsh v. Dwight, 40 N. Y. App. Div. 513 (1899).
3-Chicago, St. Louis \& N. O. R.

Co. v. Pullman Southern Car Co., 139 U. S. 79 (1891) [237]. 
combination of competitors does not result in a unit occupying a preponderant position in the business it is valid.4

\$28. So where there are mutual exclusive contracts of sale and purchase entered into by parties who are combining different resources-i. e., one possessing mines for the raw material, another skill and labor, and a third the manufacturing plant using the raw material-the contracts are valid though they eliminate a possible competition between the units so combining and to that extent, at least, tend toward monopoly. The considerations in favor of permitting a combination of the resources of several in a common enterprise which is necessary to the fostering and developing of trade and industry overcome such objections as inhere in the elimination of competition and tendency toward monopoly in the case put, provided always that there is no exclusion of others from the business by a unit holding a preponderant position. ${ }^{5}$

\$29. If, however, the exclusive contract of sale and purchase is part of a scheme of so many similar contracts that a combination is effected occupying a preponderant position in the entire business, there is at least a prima facie inference of an intent to monopolize by excluding others from the business and the contract and combination are illegal. ${ }^{6}$

§30. Suppose now that a local telephone company, depending upon special franchises for its operation, makes an exclusive connecting arrangement with a long distance company which also operates under special franchises. This is a combination between the local and long distance companies. Its tendency is to keep out of the field any other long distance company because such a company cannot secure the local connection which it needs. Its tendency is also to keep out of the field any other local company operating in the same place because such local

4-Post \&\& 53-59. As applied to exclusive contracts to sell a product to a competitor see Van Marter v. Babcock, 23 Barb. (N. Y.) 633 (1857).

5-Southern Fire Brick \& Clay Co. v. Garden City Sand Co., 223 III. 616 (1906) [230].
6-Continental Wall Paper Co. v. Voight \& Sons Co., 212 U. S. 227 (1909) [799, 1211]; Arnot v. Pittston \& Elmira Coal Co., 68 N. Y. 558 (1877) [224]. See post \& 49. 
company cannot secure the long distance facilities which it needs. These tendencies, which in an ordinary trading and manufacturing business, free to all to enter, would be too slight to outweigh the desirability of maintaining the freedom to contract, are decisive against the validity of the contract between the telephone companies.? The same reasoning makes exclusive contracts between the local telephone company and its subscribers illegal. The local telephone business being necessarily unfree to the public to enter, any exclusive contract with a subscriber which would tend to keep out of the telephone business any other company admitted to do business by the public authorities would be an illegal attempt at monopoly. ${ }^{8}$

The difference between these eases and the Pullman Palace Car case ${ }^{\theta}$ is this: In the Pullman case the business of making sleeping ears was free to others to enter and the single contract in question did not make it appreciably less so, nor did it tend to exclude from the field other railroad companies to which the public authorities might choose to give a franchise to build and operate a railroad.

7-Union Trust \& Savings Bank v. Kinloch Long Distance Telephone Co., 258 III. 202 (1913) [242]; United States Telephone Co. v. Central Union Co., 171 Fed. 130 (1909), 202 Fed. 66 (1913). Of course, the exclusive contract is also illegal, because it prevents the local company from performing its duty to the public by connecting with other companies and giving the service to the public which such connections would have enabled it to do.

8-Central New York Telephono \& Telegraph Co. v. Averill, $199 \mathrm{~N}$. Y. 128 (1910) [249]. 9-Ante 827 . 


\section{CHAPTER IV}

CONTRACTS (1) TO KEEP UP THE PRICE ON RESALE AND (2) TO BUY OR USE OTHER ARTICLES IN CONNECTION WITH THOSE SOLD

\section{Section 1}

\section{CONTRACTS TO KEEP UP TIE PRICE ON RESALE}

§31. Suppose a manufacturer, whose goods are neither patented nor subject to any copyright and are in competition with similar goods of other manufacturers and not the subject of any public necessity, and who does not occupy any preponderant position in the business in which he is thus engaged, sells his commodity to retail distributors with the covenant by them not to sell, and that the goods are not to be sold by anyone, for less than certain prices. If such a contract is valid, is it enforceable between the parties by injunction? If so, is it enforceable specifically in equity against third parties who take with notice of the restrictive covenant? These are important questions, but they are subordinate to the settlement of the validity of the contract as between the parties.

\$32. Before the decision in the United States Supreme Court of the Dr. Miles Medical Co. case, ${ }^{1}$ it had been held in England and in several states of the Union-that is to say, in a number of common law jurisdictions where the question arose-that such a contract was valid as between the parties so that damages for the breach might be recovered ${ }^{2}$ or an injunction against the breach obtained. ${ }^{3}$ In one case, at least, the injunction was

1-Dr. Miles Medical Co. v. Park \& Sons Co., 220 U. S. 373 (1911) [838].

2-Elliman Sons \& Co. v. Carrington \& Son, L. R. [1901] 2 Ch. 275; Garst v. Harris, 177 Mass. 72 (1900).
3-Grogan v. Chaffee, 156 Cal. 611 (1909) [251]; Garst v. Charles, 187 Mass. 144 (1905). See also Clark v. Frank, 17 Mo. App. 602 (1885); New York Ice Co. v. Parker, 21 How. Pr. (N. Y.) 302 (1861). 
allowed against third parties who had notice of the contract and who had procured an original party to the contract to purchase and resell to the defendant so that the defendant might sell for a lower price than that specified.4 Recently, however, in the Dr. Miles Medical case 5 the United States Supreme Court has held that no injunction should issue against the third party who took the commodity with notice of the restrictive agreement. It made no difference that the bill alleged and the demurrer admitted that the defendant sought to sell the complainant's goods to others who might sell them at cut rates and "thus attract and secure custom and patronage for other merchandise, and not for the purpose of making or receiving a direct money profit," and for this purpose procured the commodities from the complainant's "wholesale and retail agents" by "false and fraudulent representations and statements, and by surreptitious and dishonest methods, and by persuading and inducing directly and indirectly" a violation of their contract. It should also be noted that the decision of the United States Supreme Court did not go on the ground that equity would not give specific performance of a restrictive covenant relating to the disposal of personal property, or that specific performance in general could not be given against a third party who took property with notice of the restriction. The court went solely on the ground that the agreement was illegal betwcen the parties and not enforcible in any kind of an action.

This sharp division of opinion between the United States Supreme Court and the courts of other jurisdictions justifies an examination of the merits of the opposing contentions.

§33. The United States Supreme Court first makes the point that the seller cannot control the passing of title to future purchasers by requiring that title shall pass only at certain prices. Such an attempt, if successful, would, it insists, impose an illegal restraint or forfeiture upon alienation. If this be a sound principle and applicable, it would be no answer to it that there is no restriction upon the passing of title, but only a contract as to the price which the purchaser may ask upon a resale. If

4-Garst v. Charles, 187 Mass. 144 (1905).

\& Sons Co., 220 U. S. 373 (1911)

5-Dr. Miles Medical Co. v. Park [838]. 
such an agreement is enforced specifically in equity between the parties and against third parties with notice, there is produced the effect of a restraint on the alienation of the commodity itself. If an attempt to do the latter is illegal, certainly equity would not permit the former. If damages may be collected for the breach of the attempted contract in question there is, to a less degree only, a deterrent to alienation. Ignoring, however, the decisive effect of the rule forbidding restraints on alienation, the Supreme Court considers the validity of the arrangement merely as an agreement between the parties. This agreement it finds is illegal because it is one of a scheme of contracts with many retailers which operates as an arrangement between all the retailers to eliminate competition between themselves and to fix the price at which they will sell a given commodity. This, it is said, is as objectionable as if the dealers themselves had combined and agreed upon prices generally.

§34. All this is a faithful adherence to the outward form of certain rules without, it is believed, any regard for their actual meaning.

§ 35. We have, for instance, a faithful adherence to the form of the rule that restraints and forfeitures upon alienation of absolute interests in personal property are illegal. It is entirely overlooked that this expresses a rule of public policy and is properly qualified whenever the courts have to deal with a distinctive transaction which does not infringe the policy which the rule carries out. Thus one may provide for forfeiture upon alienation to a particular person or group of persons. ${ }^{6}$ Some cases have even gone so far as to permit a forfeiture on alienation to any one except a certain group of persons. ${ }^{7}$ The question always is: has the restraint or forfeiture on alienation been restricted in so distinctive a way that the public policy behind the rule has not been infringed. Perhaps it would be better to say that, upon a balance of all considerations, the freedom of action of the party restricting alienation to some extent outweighed the dangers to the public from the limitation on aliena-

6-Littleton 361.

7-Doe v. Pearson, 6 East 173 (1805); In re Macleay, L. R. 20 Eq. 186 (1875). Contra, Attwater
จ. Attwater, 18 Beav. 330 (1853). And see In re Rosher, $26 \mathrm{Ch}$. Div. 801 (1884). 
tion. The moment the case in question is approached in this way, what do we find? The manufacturer is in the business of selling products to the public. He cannot prosper unless sales are made. His goods are in competition with goods of other manufacturers who are as strong commercially as he is. These are distinctive features which the courts can lay hold of. They automatically require a price at which the manufacturer's goods will sell. This means that any restraint or forfeiture on alienation is reduced to the minimum. It means that there is a restraint or forfeiture on alienation to the class of people who will buy only at the reduced price which dealers not subject to the contract might make. The distinctive feature of the transaction makes it clear that this will be a small group in comparison with those who are ready to buy at the established price. Properly analyzed, the restraint or forfeiture on alienation, whether it proceeds from an expressed forfeiture of the title on alienation, or a restraint on its alienation below a certain price, or from the specific enforcement of the contract in equity, is reduced to such a point as to exclude it from the infringement of any public policy against general provisions of forfeiture or restraints on alienation of personal property. When we add the special grounds for freedom of economic action in transactions having the distinctive features of this one, the validity of the arrangement in question should not be in doubt.

§36. The manufacturer of a "specialty" or of "branded goods" succeeds commercially by doing a large part of the selling himself. He packs his own goods; he standardizes them; he advertises them in competition with similar goods of other equally strong manufacturcrs. The only thing he does not do is to distribute them. He cannot succeed if he attempts to do that. These goods are of the sort that the purchaser comes to know and to eall for wherever he is and he pays for them, very largely, over the counter of the distributor. The manufacturer, therefore, needs a large number of convenient distributing points. He needs all the groceries in the United States, or all the pharmacies. These are not really purchasers of goods for sale. They are distributors of goods for the manufacturer-the manufacturer having, by his advertising, standardizing, and packing, done a large part of the business of selling. Now comes the 
prime difficulty with this system of selling. Grocers in small groups all over the United States compete with each other. So do the owners of pharmacies in small groups. The smaller retailer is in competition with the better organized department store. The moment that the retailers are permitted to cumpete with each other as to the price of "specialty" or "branded" goods, the manufacturer's distributing plan, which is vital to his success, is impaired. If his goods are very popular, some retailer or department store will advertise a cut rate below cost in order to attract customers to whom other goods will be sold at a compensatory profit. Such a course disrupts the manufacturer's distributing units. Others who cannot or will not meet the cut cease to be interested in carrying or pushing the manufacturer's goods. This arrangement tends to exist everywhere, because some unit in each locality will always be in a state of cutting prices on a popular branded article in order to stimulate general trade for the unit.

\$37. This is the condition which the manufacturer seeks to meet by his contract to stabilize prices upon resale. That such contracts are necessary to this method of doing business is plain. That the method of doing business itself has some advantages to the public is equally clear. It centralizes advertising and therefore saves greatly on this item. It centralizes the labor of packing, which saves also on the cost of the article. It standardizes articles so that the time spent at the counter in determining what to buy is cut down; and in this way the selling cost is reduced. It is efficient in service because of the large number of convenient distributing points which are used. To tell the manufacturer that he cannot work out the marketing end of his business by the method in question is to tell him that he cannot distribute most efficiently through a large number of retailers without suffering the consequences of their tendency to compete with each other. This is to condemn a new method of conducting business to inefficiency and waste, or to disrupt it entirely. Such a course neglects the fact that while title technically passes to the retailer, the manufacturer is in reality, to a considerable degree, the seller by reason of his having done a large and expensive part of the work. of selling to the ultimate consumer. It overlooks the fact that he is, in a sense, a partner 
with the retailer until the goods have come to the ultimate consumer, and as such is entitled to control the price in the interest of his method of distribution.

\$38. Economists and students of business may discuss whether the method of manufacturing and selling "specialty" and "branded" goods coupled with contracts on the part of the retailer to keep up the price on resale is a valuable or the wisest method or not. There may be differences of opinion about the matter. Where, however, there are opposing advantages and disadvantages in the way the business is conducted and where it remains a matter of opinion or speculation whether good or ill to the public preponderates, the fundamental social interest in the freedom of economic action requires the courts to refrain from throwing a monkey wrench into the commercial effort in question.

\$39. When the court declares the contract to keep up the price on resale is invalid because it is the same as a contract or combination between all the retailers to eliminate competition between themselves and fix prices, we again have a faithful adherenee to the form of a legal rule without the slightest regard for its substance or the reasons which determine its limitations. When retailers who are competing combine and eliminate competition between them by agreements as to prices, we have the recorded assumption that in their sphere of business, at least, they have a preponderant or monopolistic position, and that they will keep it by using their power to exclude others by unfair and illegal methods of competition. ${ }^{8}$ The agreement as to price is the admission of facts whieh make an illegal attempt at monopoly. But where the manufacturer sells his "specialty" or "branded" goods to distributors who agree to keep up the price on resale, we have no such admission, or, at least, the inference of any such admission is rebutted. The manufacturer has no preponderant position in the business. He is in eompetition with many other manufacturers who sell goods of the same sort. Nor is the position of the manufacturer preponderant beeause he deals through a large number of retailers who agrec to keep up the price on resale. These retailers may handle the goods of the competitors of the manufacturer on exactly the same terms,

8-Post $\$ 70$. 
or on terms more favorable to the buyers. The manufacturer, by reason of having taken care of the advertising, standardizing, and packing of the goods, and requiring of the retailer only the function of distributing and receiving payment, is in substance a partner with the retailer in selling, and has a legitimate interest in controlling the price to prevent the disorganization of his distributing system. This does not eliminate any competition between the manufacturer and other manufacturers who are doing the same sort of business. There is no exclusion of others from the manufacturing business, or from the business of retailing. It is the free competition among the manufacturers which determines the price to the public. The contract to keep up the price on resale is thus reduced to a device to preserve the most effective distributing organization for the manufacturer, who is also in part, at least, the actual seller as well.

\$40. In Bobbs-Merrill Co. v. Straus, ${ }^{9}$ the supreme court held that the holder of a copyright on a book who had sold it with a restriction that it was not to be resold for less than $\$ 1.00$ could not have an injunction against the violation of the restriction by a third party who had notice of it. This ruling seems to have proceeded solely upon a construction of the copyright act; for the jurisdiction of the court was founded, not on diverse eitizenship and the specific performance of a restrictive agreement, but upon the protection afforded by the federal statutes against infringement of copyrights. The copyright act gave the holder of the copyright the "sole right of vending the same." This was construed to include no right whatever to fix the price at which the copyrighted article might subsequently be sold. In Bauer v. O'Donnell ${ }^{10}$ the same ruling was made where a patented article was involved. This also proceeded upon the construction of the patent act, which gave the patentee the "exclusive right to make, use and vend the invention or discovery." In Straus v. Victor Talking Machine Co. ${ }^{11}$ an attempt to retain title to the patented article in the manufacturer who merely licensed the use subject to a condition and covenant that the article should not be resold for less than a certain price was equally ineffective and unenforcible. Again an injunction against

9-210 U. S. 339 (1908).

10-229 U. S. 1 (1913).

11-243 U. S. 490 (1917). 
a third party who had no contract relations with the plaintiff, but who had notice of the restriction, was denied.

Suppose in these cases the complainant had abandoned all reliance upon the copyright or patent act; and had treated the articles sold as the "specialty" product of his manufacture, which he desired to market by securing a covenant requiring the price to be kept up on resale. Suppose the United States court secured jurisdiction on the basis of diverse citizenship ; or suppose the suit were in a state court and the covenants were of the sort of which equity gave specific performance by injunction even against third parties with notice. Would the result have been the same? Clearly it would if the Dr. Miles Medical case were followed. ${ }^{12}$ But suppose the result in that case had been to enforce the restriction by injunction; would the same result have been reached in a case where a patented or copyrighted article was being marketed? Perhaps so and perhaps not. If the patent were a fundamental one which controlled an entire industry, like the original Bell Telephone patent, a court of equity might say: "You have a monopoly by the patent or copyright act, but we shall not aid that monopoly by giving you anything beyond what you are entitled to by the terms of the statute." On the other hand, if the patent or copyright gave no monopoly in the given business-if the patented or conyrighted article was in competition with other artieles of the same sort-the patented or copyrighted article should not be any worse off for that reason. The same relief, therefore, might be given as in the case of "specialty" or "branded" goods which are in competition with others of the same sort.

\section{SECTION 2}

CONTRACTS TO BUY OR USE OTIIER ARTICLES IN CONNECTION WITH THOSE SOLD

§41. The Supreme Court of the United States first held, in Henry v. A. B. Dick Co., ${ }^{13}$ that where the holder of a patented

12-Dr. Miles Medical Co. $\mathbf{0}$ Park \& Sons Co., 220 U. 8. 373

13-224 U. S. 1 (1912).

(1911) [838].

Kales Sum. R. of T. -3 
article licensed its use, the license may be made subject to the condition or stipulation that the licensee would use with the patented article only unpatented accessories, manufactured and sold by the licensor, and that upon the violation of this stipulation there would be an infringement by the user of the patented article. In the recent case of Motion Picture Patents Co. v. Universal Film Manufacturing Co. ${ }^{14}$ the decision in the Dick case was overruled; and it was held that the violation of the condition or stipulation does not make the use of the patented article an infringement. In both cases alike the court appears to have been obliged to deal with a controversy between the parties as if it involved the infringement of a patent; for only on that ground did the United States court obtain jurisdiction. The Dick case proceeded upon the theory that the act relating to patents permitted the holder of the patent to license the use of the patented article upon such terms as he saw fit; and if the conditions and stipulations which he imposed were not lived up to, then the license failed and there was a user without licensethat is to say, an infringement. This line of reasoning the Motion Picture Patents case denies. It declares that the holder of the patent may license the use of the article or not, as he pleases; but that the act gives him no authority to license subject to the condition or stipulations in question, which, if not adhered to, will cause the user to be an infringement.

§42. The Dick ease and the Motion Picture case have to do only with a construction of the patent act; but behind the decision in the Motion Picture case is the intimation that the arrangement there attempted is so far contrary to the public interest that the patent act should not be construed to permit it. Suppose, then, that instead of seeking relief for an infringement, the complainants in the Dick case and the Motion Picture case sought damages for the breach of a contract on the part of the licensee to use only such accessories with the patented article as were furnished by the licensors. Is it a defense to such suit that the contract is illegal?

§ 43. The reasoning of the court in the Dr. Miles case has nothing to do with this problem. The result of the Dr. Miles 
case went upon the illegality of a restraint or forfeiture on alienation which was attempted to be imposed, and the fact that there was in effect a combination of retailers under contract with each other to fix the price of a commodity. Neither line of reasoning touches the contract by a purchaser to use only certain accessories with the article purchased. If such contracts are illegal between the partics, it must be on some ground not articulated or applied in the Dr. Miles case. What can it be?

$\S 44$. Suppose A has a mule; can he sell him to B subject to the covenant by $B$ to curry him only with such combs as are furnished by A? Why not? A does not have to scll. Can he not, as one of the terms of the selling, require the purchaser to buy something else? What is the objection to limiting what $B$ must also buy to an article used in conneetion with the ehattel sold? The courts have not been troubled with such a case becanse trading in mules is carried on in such a way as to make stipulations of the sort suggested impracticable. Such conditions and stipulations ean only be exacted where the article sold is of special and peculiar value - as is more frequently the ease witl patented articles. Suppose, then, that $\Lambda$ had a valuable collection of paintings: could he sell each article with the stipulation that the purchaser should use only such eleaning and preserving preparations for the picture as were sold by A? Why not? The only difference in the cases is that now $\mathrm{A}$ is in a strong enough position in the market to exact the stipulation.

$\S 45$. Where $\mathrm{A}$ has a patented article the situation is precisely the same. The patent laws, by giving him the right to prevent anyone else from making the patented article, place $A$ in the unique position of being able to control absolutely the sale of an article of special and peculiar value. He can sell it or not as he pleases. He can prevent anyone else from selling it. Having such an article, A bargains for the sale or license of it as he would any other piece of personal property. Is he, then, debarred from selling it on the best terms possible? Is he barred from saying, "I will not sell unless the purchaser buys something else with it which is not patented"? Is he forbidden to make a bargain that unpatented accessories which are used in connection with the patented article shall be only those made and sold by the licensor or holder of the patent? How can there 
be any other answers to these questions than an emphatic negative? When A has goods to sell, is it not in the public interest that he should get as much for them as possible? Is he not free to make the best terms possible? If he can require the purchaser to buy other goods, and thus secure a market for the sale of such other goods, in competition with other parties, is not that his privilege? Since when has it been true that this timehonored method of trading has become illegal? If such terms are legal, is it not equally legal for the purchaser to require that unpatented accessories used with a patented article sold shall be purchased from the seller? Are the rights of a patentee in this respect less than the rights of the owner of a mule or a picture?

\$46. If the stipulation in question makes a legal and enforceable contract at law, then the question arises whether equity will give specific performance of it as between the original parties and as against third parties who take the patented article with notice. This depends upon whether the remedy at law is inadequate. Suppose it is. Suppose, also, the fact that the restrictive covenant is connected with the sale or license of a chattel is no objection to the specific enforcement of the covenant against third parties taking the chattel with notice. ${ }^{15}$ Is there any defense to an action of specific performance that the contract, while not illegal in law, is so far unfair, unconscionable, or contrary to the interests of the public that equity should not give specific performance? Such a defense might exist, especially where the contract was supplementary to a combination occupying a preponderant position in the business and part of a system of contracts used for the purpose of compelling others to come into the combination or be excluded entirely from the business. It is submitted, however, that no such defense to specific performance existed in the Dick case or the Motion Picture case.

15-John Brothers Abergarw Brewing Co. v. Holmes, I. R. [1900] 1 Ch. 188; Francisco v. Smith, 143 N. Y. 488 (1894); Standard Co. v. Methodist Co., 33 N. Y. App. Div. 409 (1898); Mur- phy v. Christian Press Assn., $38 \mathrm{~N}$. Y. App. Div. 426 (1899); New York Co. v. Hamilton Co. 83 Hun 593 (1895), 28 N. Y. App. Div. 411 (1898). 
\$47. If, then, the condition or stipulation entered into by the licensee or purchaser of a patented article, that he will not use the same except with unpatented accessories furnished by the licensor or seller is not illegal-and if it is specifically enforceable in equity as between the parties and as against third parties taking with notice-what possible objection is there to permitting a construction of the patent act which would permit the holder of a patent to make a license or sale of a patented article subject to the condition or stipulation that it be used only in connection with certain unpatented accessories sold by the licensor, with the result that upon a breach of the stipulation or condition the continued user of the patented article would become an infringement? Perhaps this: that so long as the stipulation is justified under the patent act it confers an absolute statutory right in equity to obtain specific performance in the guise of enjoining an infringement. On the other hand, so long as it is merely a contract of which equity gives specific performance under certain terms and conditions, its enforcement by injunction may be so far limited and controlled that the results will not be unconscionable as between the parties or contrary to the interests of the public. In short, a stipulation which requires specific performance as a matter of right might be regarded as contrary to public policy when a stipulation which was valid at law between the parties, and the specific performance of which was in the control and discretion of a court of equity, might be regarded as valid.

\section{Section 3}

\section{CONCLUSION}

§478. What has been said by way of objection to the Dr. Miles case and the Motion Picture Patents case has been based upon the assumption that there was no objection to a court of equity giving specific performance of restrictions as to the use of chattels even against third parties taking the chattels with notice of the restrictions. This proposition, however, may be open to question. It is only recently that courts have been called upon to give specific performance in such cases. While 
the justice of so doing in particular instances may be apparent, the courts must face the fact that they are opening up a wide field for the creation of what are, in effect, property interest servitudes in chattels. When the covenantee or promisee can say to the buyer of a chattel, "You cannot use what you have bought unless you do so in the following manner," or, "You cannot sell it unless at a certain price," and if this position on the part of the seller can be enforced specifically against any holder of the chattel taking with notice, a servitude has been created in the chattel in favor of the promisee and perhaps in favor of whomever is running the business of the promisee. It may be that the Dr. Miles case and the Motion Picture Patents case both indicate a reaction against permitting the specific performance of restrictions as to chattels against third parties with notice. Perhaps the undesirable features of having vast numbers of chattels in commerce subject to all manner of property servitudes has been borne in upon the Supreme Court of the United States. Perhaps a general dislike for such servitudes may have been translated by the court into what appears to the casual reader of the opinions to be a condemnation of the particular restrictions involved.

\$47b. The following discriminations are suggested:

1. Stipulations and conditions requiring the buyer of a chattel to keep up the price on resale, or to buy or use other articles in connection with those sold, are valid between the parties and may be enforced in suits at law for damages.

2. When the articles sold are patented or copyrighted, the license to use them cannot be made subject to such conditions and stipulations so that the failure to observe them will give rise to the statutory action in equity for an infringement.

3. Such restrictive contracts may be specifically enforceable in equity as between the parties.

4. Whether specific performance will be given to the promisee against third parties taking the chattel with notice of the restrictions may be open to debate. Specific performance should not, however, be refused because the contract is illegal as between the parties. It should not be refused because there is anything inimical to the interests of the public in such restrictions as were involved in the Dr. Miles and Motion Picture Patents cases. 
It is entirely conceivable, however, that some restrictions might be of such character that while they were valid at law or even in equity, as between the parties, it would be proper, in the interests of the public, to refuse enforcement of them against third parties, even with notice. If specific performance against third parties is refused in the case of restrictions such as were involved in the Dr. Miles and Motion Picture Patents cases, it should be on the ground that it is against public policy that any servitudes be created in chattels by the specific performance in equity of restrictions against third parties with notice. 


\section{CHAPTER V \\ COMBINATIONS \\ [GOOD AND BAD TRUSTS] 1}

§ 48. The term "trusts" has now come to refer to extensive combinations of capital in the commercial and industrial world, regardless of what the form of the organization may be. The combination may be by agreement of the units combining that they will sell through a common board or committee, ${ }^{2}$ or by the device of trustees holding under a trust agreement stock controls in subsidiary corporations, or the controlling interests in partnerships and other forms of industrial and commercial units, ${ }^{3}$ or by a parent corporation holding stock controls in subsidiary corporations, ${ }^{4}$ or by the actual purchase of plants and their operation as a single industrial unit by a single corporation. ${ }^{5}$ In describing the size of the combination which is sufficient to warrant its being called a "trust," we may adopt the phraseology of the govermment in its brief in the International Harvester and Steel cases. The combination to be a trust must embrace "units which together occupy a preponderant position in a given industry." To ask whether a trust is good or bad is only to ask where the line shall be drawn between combinations which

1-Reprinted from 30 Harv. L. Rev. 830 .

2-This was the form of the combination attacked by the government in United States $v$. Addyston Pipe \& Steel Co., 85 Fed. 271 (1898) [625]; Addyston Pipe \& Steel Co. v. United States, 175 U. S. 211 (1899) [772, 1047].

3-This was the form of the combination known as the Standard Oil Trust under the Standard Oil Trust Agreement in 1882 . State v. Standard Oil Co., 49 Oh. St. 137,
30 N. E. 279 (1892) [649]; Standard Oil Co. v. United States, 221 U. S. 1 (1910) $[780,1072]$.

4-This was the form of organization of the Standard Oil Company of New Jersey as it was reorganized in 1899. Standard Oil Co. v. United States, 221 U. S. 1 (1910) $[780,1072]$.

5 -This was the form of the combination of the International Harvester Company. United States v. International Harvester Co., 214 Fed. 987 (1914). 
are legal and those which are illegal. It will be convenient in the beginning to indicate, first those that are clearly illegal, and then those that are clearly legal. By this process we shall arrive at the debatable ground.

\section{Section 1}

\section{COMBINATIONS CLEARLY ILLEGAL}

849. Since the Standard Oil and Tobacco Cases, ${ }^{6}$ it has become articulate that a combination of properties (in whatever form) which, by reason of its size and preponderant position in the business, has the power and the purpose, or uses its power to exclude others from the business by illegal acts and unlawful and unfair methods of competition, is an attempt at monopoly, and a restraint of trade and illegal at common law, and, if interstate commerce is involved, under the Sherman Act. It is what may be called a bad trust.?

6-Standard Oil Co. v. United States, 221 U. S. 1 (1910) [780, 1072]; United States v. American Tobacco Co., 221 U. S. 106 (1910).

7 -Continental Wall Paper Co. v. Voight \& Sons Co., 212 U. S. 227 (1909) [799, 1211]; United States v. Motion Picture Patents Co., 225 Fed. 800 (1915) (semble); United States v. Eastman Kodak Co., 226 Fed. 62 (1915); 230 Fed. 522 (1916); United States v. Corn Products Refining Co., 234 Fed. 964 (1916); Dunbar v. American Telephone Co., 224 Ill. 9, 79 N. E. 423 (1906); 238 IIl. 456,87 N. E. 521 (1909) [105]; Distilling \& Cattle Feeding Co. v. People, 156 Ill. 448, 41 N. E. 188 (1895); Arnot v. Pittson \& Elmira Coal Co., 68 N. Y. 558 (1877) [224].

One of the early examples of combination (often on rather a small scale) which had the purpose to ex- cludo others by means of an unlaw. ful excluding practice, is found in the cases where several competitors secretly combined and eliminated competition, while pretending to the public to be competing. Craft v. MeConoughy, 79 Ill. 346 (1875); Fairbank จ. Leary, 40 Wis. 637 (1876). This device obviously deceived the public and tended to keep others out of the business, since ono would be less likely to enter a field already occupied by a considerable number of competitors, than if obliged to contend with only one other unit.

On the samo principle the secret combination of bidders not to bid against each other at an auction is illegal. Gibbs v. Smith, 115 Mass. 592 (1874); Woodruff v. Berry, 40 Ark. 251 (1882); National Bank of the Metropolis v. Sprague, 20 N. J. Eq. 159 (1869). 
\$50. It seems incredible that anyone ever should have doubted the soundness of this proposition. The common-law conception of monopoly was that of a business carried on to the exclusion of others. ${ }^{8}$ Formerly this was effected by the exercise of the proper governmental authority which directly excluded all but the favored person from carrying on the business and imposed penalties upon anyone who violated the excluding mandate. When, however, the crown attempted to grant the privilege of carrying on a trade exclusively of all others its action was held void in the Case of Monopolies. ${ }^{9}$ In this decision the policy of the common law against monopoly in the sense of a special privilege to carry on a business to the exclusion of all others was established and found effective to nullify the grant of the crown. Quite recently large aggregations of capital occupying a preponderant position in the business have discovered that they possess a power (resulting from their size) to indulge in practices which actually operate to exclude smaller units from the field. Some of these were plainly unlawful, such as inducing another trader to break his contract, fraud, libel, intimidation, coercion, and transportation rebates. These may be called "unlawful competition." 10 Other excluding practices were more subtle and have become known as "unfair methods of competition." They are methods which may be lawful and proper when used by one unit against another which can retali-

8-INST. 181; Kellogg v. Larkin, 3 Pinn. (Wis.) 123 (1851) [142]. Chappel v. Brockway, 21 Wend. (N. Y.) 157, 163 (1839). ("The defendant can gain nothing by giving the transaction a bad name, unless the facts of the case will bear bim out. $\mathrm{He}$ calls this a monopoly. That is certainly a new kind of monopoly which only secures the plaintiff in the exclusive enjoyment of his business as against a single individual, while all the world beside are left at full liberty to enter upon the same enterprise."')
The Califormia Steam Navigation Co. v. Wright, 6 Cal. 258 (1856) (last quotation approved); HAwK. P. C., bk. 1, ch. 29 (quoted in the opinion of the court in Standard Oil Co. v. United States, 221 U. S. 1 (1910) [1072]; Mitchel v. Reynolds, 1 P. Wms. 181 (1711) [1]. See also the many cases where the absence of any exclusion of others is noted as minimizing the tendency toward monopoly. Post, \&55, note 19.

9-11 Rep. 84 (1603).

10-See WrMan, Control of the MARKET, 36 et seq. 
ate on fairly even terms with the same methods. ${ }^{11}$ They become unfair and unlawful at least when used by a unit occupying a preponderant position against a smaller one, which, because it is smaller, cannot retaliate effectively. ${ }^{12}$ Of these the most obvious and best known is "local price-cutting." 13 The large unit can put the small one out of business by price-cutting below cost in the locality or the market which the smaller unit serves. By thus demolishing each small unit singly it may exclude all from the field. This was not, of course, as effective as an act of parliament. Such methods might never result in an actual monopoly. But they were effective to accomplish enough in that direction to be an illegal attempt at monopoly. If the crown was denied on grounds of public poliey any power to grant an exclusive privilege to carry on a business, is it not quite plain that a similar privilege granted by a "trust" to itself would be an illegal attempt at monopoly and a restraint of trade cntirely contrary to the common law, and, if interstate commerce was involved, void under the Sherman Act?

\$51. The fact that the mere combination of competing railroads, or other competing publie service corporations operating under special franchises, is illegal at common law and under the Sherman Act, without regard to any purpose to monopolize, or excluding practices, ${ }^{14}$ is an application of the principle which underlies the Standard Oil and Tobacco cases. Railroads and many other public utilities cannot be constructed and operated without special legislative authority, the exercise of the right

11-Mogul Steamship Co. v. McGregor, Gow \& Co., L. R. [1892] A. C. 25 [309].

12-Post 8893 et seq.

13-Other methods of unfair competition are listed and explained in an admirable article on Unfair Competition by William S. Stevens, 29 POL. ScI. QUART. 282, 461.

14-United States v. Trans-Missouri Freight Ass'n, 166 U. S. 290 (1897) [862]; United States v. Joint-Traffic Ass'n, 171 U. S. 505 (1898) [904]; Northern Securities Co. v. United States, 193 U. 8. 197
(1904) [910]; United States $\nabla$. Union Pacific R. Co., 226 U. S. 61, 470 (1912) [981]; Gibbs v. Consolidated Gas Co. of Baltimore, 130 U. S. 396 (1889) [721]; People v. Chicago Gas Trust Co., 130 Ill. 268, 22 N. E. 798 (1889) [735]; Chicago Gas Light Co. v. People's Gas Light Co., 121 Ill. 530, 13 N. E. 169 (1887); Chic. M. \& St. P. Ry. Co. v. Wabash, St. L. \& P. Ry. Co., 61 Fed. 993 (1894); Texas \& Pac. Ry. Co. v. Southern Pac. Ry. Co., 41 La. Ann. 970, 6 So. 888 (1889). 
of eminent domain, and the right to use or cross the public streets and highways. It follows that the very nature of the business and the special privileges required are such that it is against the public interest to allow anybody and everybody to engage in it. It follows that one who is given the special privileges required is protected by the proper goverumental authority from any competition. The exclusion of the public is supplied by the state just as clearly as where an act of parliament granted to A the exclusive privilege of carrying on a business and penalized all others who attempted to do it. If several persons are permitted to construct and operate the public utility in question on a competitive basis, they are still protected from any competition on the part of others. The field of this sort of business is unfree. Furthermore, the fact that several are permitted to operate a public utility in competition is a determination by the public authorities that competition between the units in the field is desirable. Under such circumstances the elimination of any existing competition between any of the units is, in and of itself, illegal. It defies the policy determined by the public authorities who have permitted a number of competitors to enter the field. It tends directly to produce monopoly regardless of any excluding purposes or practices because the exclusion of others is provided for by the non-action of governmental authority.

\$52. It is entirely possible that the public may be excluded from a given business by the conditions under which it is carried on or by an actual limitation of a natural resource or both. Thus, if several competitors controlled all the known mineral deposits of a certain sort, it might be that any combination between them would be illegal. Certainly any combination which resulted in one having a preponderant position in the business might be regarded as, in and of itself, illegal. The field would be inherently unfree at the time the combination occurred. So those who controlled the only mineral deposits which were, on account of the transportation cost from other sources, practically available for a certain considerable area, might not be permitted to combine to the extent of conferring upon one unit a preponderant position in that business. ${ }^{15}$ The so-called nec-

15-See Morris Run Coal Co. v. Barclay Coal Co., 68 Pa. St. 173 (1871) [680]; Cummings v. Union
Blue Stone Co., 164 N. Y. 401, 58

N. E. 525 (1900) [712]. 
essaries of life must be had for use at once, or within a brief space of time. There may be a sufficient quantity on hand in the world at large, but the users cannot wait to have reserves brought up from a distance. There will be an ample supply after the next year's crops are harvested, but the population must have the present supply before that time. Such circumstances create the excluding conditions. Hence, a combination which attempts to secure the reserves of such supplies at any given point, and goes so far at least as to sceure a preponderant position in the control of the market, has all the elements of an illegal attempt at monopoly. During the time that the supplies acquired are needed, the market is not free. All but thcse actually in it are excluded. The only protection of the public from monopoly prices is the maintenance of the status quo of existing competitions, or at least the prevention of any sudden and violent change in the competitive status of the units engaged. This is the basis for the illegality of the so-called "corner." 16 It makes no difference, of course, whether there is involved merely the union of properties by purchase, or of properties and managers by combination.

\section{SECTION 2}

\section{COMBINATIONS CLEARLY LEGAL}

853. Where a business is normally free to all to enter and no excluding conditions exist and no excluding practices are indulged in, it is clear that there may be a great deal of lawful combination among competitors which necessarily eliminates competition between the units combined. Indeed, it may safely be affirmed that all such combinations which do not result in a unit occupying a "preponderant position in the industry" are valid. This is clear where the combination of properties occurs by the purchase of the business of one competitor by another, and where not only is the sale valid, but a restrictive covenant on the part of the seller not to carry on the same business is also upheld. ${ }^{17}$

16-Raymond v. Leavitt, 46 Mich. 447, 9 N. W. 525 (1881); Samuels v. Oliver, 130 Ill. 73, 22 N. E. 499 (1889).
17-Nordenfelt v. Maxim Nordenfelt Guns \& Ammunition Co., [1894] A. C. 535 [33]; Diamond Match Co. จ. Roeber, 106 N. Y. 473, 
So where the combination occurs by uniting not only the properties which formerly competed but also the managers, it is valid, and restrictive covenants on the part of the managers combining not to compete have been upheld. ${ }^{18}$ These cases indicate

13 N. E. 419 (1887) [55]; Leslie v. Lorillard, $110 \mathrm{~N}$. Y. $519,18 \mathrm{~N}$. E. 363 (1888) [65]; Wood v. Whitehead Bros. Co., 165 N. Y. 545, 59 N. E. 357 (1901); United States Chemical Co. v. Provident Chemical Co., 64 Fed. 946 (1894) [98]; Kellogg v. Larkin, 3 Pinney (Wis.) 123 (1851) [142]; Chappel v. Brockway, 21 Wend. (N. Y.) 157 (1839); Van Marter v. Babcock, 23 Barb. (N. Y.) 633 (1857); Moore \& Handley Hardware Co. v. Towers Hardware Co., 87 Ala. 206, 6 So. 41 (1888); Beard v. Dennis, 6 Ind. 200 (1855); California Steam Navigation Co. v. Wright, 6 Cal. 258 (1856); Hubbard จ. Miller, 27 Mich. 15 (1873); Mapes v. Metcalf, $10 \mathrm{~N}$. D. $601,88 \mathrm{~N}$. W. 713 (1901); National Benefit Co. v. Union Hospital Co., 45 Minn. 272, 47 N. W. 806 (1891) [94]; Wickens v. Evans, 3 Y. \& J. 318 (1829) [84].

18-Dolph v. Troy Laundry Machinery Co., 28 Fed. 553 (1886); United States v. Nelson, 52 Fed. 646 (1892); Robinson v. Suburban Brick Co., 127 Fed. 804 (1904); United States v. Quaker Oats Co., 232 Fed. 499 (1916) (especially opinion of Mack, J.); Ontario Salt Co. v. Merchants Salt Co., 18 Grant (U. C.) 540 (1871) [616]; Central Shade Roller Co. v. Cushman, 143 Mass. 353, 19 N. E. 629 (1887) [601]; Gloucester Isinglass \& Glue Co. v. Russia Cement Co., 154 Mass. 92, 27 N. E. 1005 (1891); Anchor Electric Co. v. Hawkes, 171 Mass.
101, 50 N. E. 509 (1898); Skrainka v. Scharringhausen, 8 Mo. App. 522 (1880); Meredith $\nabla$. Zine \& Iron Co., 55 N. J. Eq. 211, 37 Atl. 539 (1897); Marsh v. Russell, 66 N. Y. 288 (1876); Oakdale Mfg. Co. v. Garst, 18 R. I. 484, 28 Atl. 973 (1894) [78]; Queen Ins. Co. v. State of Texas, 86 Tex. 250, 24 S. W. 397 (1893) [605]; Sayre v. Louisville Union Benevolent Ass'n, 1 Duvall (Ky.) 143 (1863); Jones v. North, L. R. 19 Eq. 426 (1875). In United States v. International Harvester Co., 214 Fed. 987 (1914), the court said, p. 999: "If the five companies which formed the International had been small, and their combination had been essential to enable them to compete with large corporations in the same line, then their uniting would, in the light of reason, not have been in restraint of trade, but in the furtherance of it; . . ." In the brief of the government presented to the United States Supreme Court in the same case it is conceded: "Nor was it intended to prohibit all combinations of competing units, but only such as are sufficiently im. portant and comprehensive to bear some reasonable relation to the evils - the breakdown of the competitive system, etc.-against which the Act was designed to guard." On page 99, in summing up, the same brief states: "It [the Sherman Act] permits combinations of com. petitive units within limits." Contra, Slaughter $\nabla$. The Thacker 
that where the combination does not occupy a preponderant position in the business, and there are no excluding purposes or practices, the mere elimination of competition between the units is not a ground for holding it illegal. The common law certainly has never attempted to put out a rule which would compel the maintenance of the status quo of every existing combination by enforcing general restraints on alienation to, and upon the freedom to contract and unite with, competitors. Neither has any court suggested that any difference of result could be made between a combination of properties which had competed, and a combination both of competing properties and managers as well. Imagine anyone objecting that all the partnerships of competing lawyers, bankers, and corner grocers were necessarily illegal because they were combinations of competing properties and managers which eliminated competition between them! Imagine anyone upholding a public policy in favor of the owner of a business having the privilege of selling his property with the greatest freedom at the best price obtainable, who would not admit the existence of the same policy in favor of a man in business selling his services and experience on the same terms!

Coal \& Coke Co., 55 W. Va. 642, 47 8. E. 247 (1904) (where, however, the opinion of the court was delivered by the dissenting member, who sets forth in full the reasons against the decision).

Not infrequently it is difficult to say whether there has been a combination by the sale of properties to 2 competitor, or a combination of properties and managers as well. For instance, when a new corporation is formed and the properties of several competing units are transferred to it in return for stock which is distributed to the stockholders or the owners of the property sold, the transaction may be looked upon as a combination of properties merely, the managers of the selling units going out of the business, or it may be that the managers of the selling units remain in the business, taking part as officers of the new corporation. Oakdale Mfg. Co. v. Garst, 18 R. I. 484, 28 Atl. 973 (1894). So where two units in the same business agree to divide the territory and make reciprocal covenants with each other not to do business in the territory assigned to the other, the transaction may be looked at either as a sale of part of the business of each, and therefore a combination of properties only, or it may be looked at as a combination of properties and managers serving the entire field in a manner mutually arranged between them. Wickens v. Evans, 3 Y. \& J. 318 (1829) [84]; National Benefit Co. v. Union Hospital Co., 45 Minn. 272, 47 N. W. 806 (1 21 ) [94]. 
\$54. The authorities which uphold the legality of combinations, whether of properties alone, or of properties and managers, where the combination does not result in a unit occupying a preponderant position in the business, are clearly sound.

$\$ 55$. Of course there is in every such case the elimination of competition between the competing units combined. This is not less in the case of the union of the properties by sales and the restriction by covenants not to compete, exacted from the sellers, than it is where the properties and the managers themselves are united. In both alike competition between the property and the managers is ended, at least for the time being. This, of course, tends in some degree toward monopoly. So long, however, as the combination does not occupy a preponderant position in the business and there are no excluding purposes or practices, ${ }^{19}$

19-In the following cases, the absence of any exclusion of others from the business was noted as minimizing the tendency toward monopoly from the elemination of competition between the units com. bined.

Diamond Match Co. v. Roeber, 106 N. Y. $473,483,13$ N. E. 19 (1887) [55]. ("But the business is open to all others, and there is little danger that the public will suffer harm from lack of persons to engage in a profitable industry";) Leslie v. Lorillard, $110 \mathrm{~N}$. Y. $519,534,18$ N. E. 363 (1888) [65] (same language).

Wood v. Whitehead Bros. Co., 165 N. Y. $545,551,59$ N. E. 357 (1901) [72]. ("But contracts between parties, which have for their object the removal of a rival and competitor in a business, are not to be regarded as contracts in restraint of trade. They do not close the field of competition, except to the particular party to be affected.' ')

Oakdale Mfg. Co. v. Garst, 18 R. I. $484,487,28$ Atl. 973 (1894)
[78]. ("But combinations for mutual advantage which do not amount to a monopoly, but leave the field of competition open to others, are neither within the reason nor the operation of the rule." Page 488: "But even so, not only is the field open to the other company, equal in strength to either of these, but it is also open to competition from companies in other parts of tho country and to the formation of new companics."')

Wickens v. Evans, 3 Y. \& J. 318, 329 (1829) [84]. ("Not a monopoly, except as between themselves; because every other man may come into their districts and vend his goods." Page 330: "If the brewers or distillers of London were to come to the agreement suggested, many other persons would soon be found to prevent the result anticipated; and the consequence would, perhaps, be, that the public would obtain the articles they deal in at a cheaper rate." )

National Benefit Co. v. Union Hospital Co., 45 Minn. 272, 275, 47 
much competition will remain, and the progress toward monopoly will be comparatively slight. Such as may occur is entirely outweighed by the public interests which are subserved by permitting the combination.

\$ 56. First, there is the social interest in individual freedom of economic action. As applied to the situation under discussion this means that there is a public policy in favor of freedom to business managers and owners to run their business as they think best, combining with others or not, as they deem advisable. It is not infrequently spoken of as the fundamental policy in

N. W. 806 (1891) [94]. ("Neither one nor both of these companies have any exclusive right to engage in this business, it being open to all. Hence this contract does not, and cannot, create any monopoly.")

United States Chemical Co. v. Provident Chemical Co., 64 Fed. 946, 949 (1894) [98]. ("The facts of this case disclose no tendency to monopoly. Monopoly implies an exclusive right, from which all others are debarred, and to which they are subservient."')

Kellogg v. Larkin, 3 Pinney (Wis.) 123, 139 (1851) [142]. ("And while we have no privileged classes here, but little individual, and less associated capital, and while our resourees are so imperfectly developed, while the avenues to enterprise are so multiplied, so tempting and so remunerative, giving to labor the greatest freedom for competition with capital, perhaps, that it has yet enjoyed, I question if we have much to fear from attempts to secure exclusive advantages in trade, or to reduce it to few hands." Page 145: "Now could the parties possibly have intended by this simple contract, to vest in the mill owners the sole exercise of the traffic in wheat, throughout the State of Wisconsin? . . . I say there was no monopoly intended, none effected. We cannot fail to perceive, that in spite of this contraet, all the rest of Wisconsin was an open and unrestricted market for the sale of wheat. And even in Mil. waukee, the market was open to the fiereest eompetition of all the world, except these obligors.')

Trenton Potteries Co. v. Oliphant 58 N. J. Eq. 507, 523, 43 Atl. 723 (1899) [161]. ("The entire capital of the country, except theirs, is free to be employed in the manufacture."')

Chappel v. Brockway, 21 Wend. (N. Y.) 157, 163 (1839). ("The defendant can gain nothing by giving the transaction a bad name, unless the facts of the case will bear him out. He calls this a monopoly. That is certainly a new kind of monopoly which only sccures the plaintiff in the exclusive enjoyment of his business as against a single individual, while all the world beside are left at full liberty to enter upon the same enterprise.") The California Steam Navigation Co. $\mathbf{v}$. Wright, 6 Cal. 258, 262 (1856) (last quotation approved). 
favor of freedom of contract, protected by the "due process" clause of our constitutions. ${ }^{20}$

20-Diamond Match Co. v. Rseber, 106 N. Y. $473,482,13$ N. E. 19 (1887) [55]. ("It is elear that public policy and the interests of society favor the utmost freedom of contract, within the law, and require that business transactions should not be trammeled by unnecessary restrictions." )

Leslie v. Lorillard, 110 N. Y. 519, 533,18 N. E. 363 (1888) [65]. ("The object of government, as interpreted by the judges, was not to interfere with the free right of man to dispose of his property or of his labor.")

Wood v. Whitehead Bros. Co., 165 N. Y. $545,551,59$ N. E. 357 (1901) [72]. ("In the present practically" unlimited field of human enterprise there is no good reason for restricting the freedom to contract, or for fearing injury to the public from contracts which prevent a person from carrying on a particular business." )

National Benefit Co. v. Union Hospital Co., 45 Minn. 272, 276, 47 N. W. 806 (1891) [94]. ("A contract may be illegal on grounds of public policy because in restraint of trade, but it is of paramount public policy not lightly to interfere with freedom of contract."')

United States Chemical Co. $\nabla$. Provident Chemical Co., 64 Fed. 946, 949 (1894) [98]. ("In discussing this phase of the subject, we must not lose sight of some other prin. ciples, the disregard of which would be more harmful to public interest than monopolies. The right to contract is a cardinal element of con- stitutional liberty, and, as such, should be jealously guarded.' ')

Anchor Electric Co. v. Hawkes, 171 Mass. 101, 105, 50 N. E. 509 (1898). ("The general principle that arrangements in restraint of trade are not favored is, however, firmly established in law, and now, as well as formerly, is given effect whenever its application will not interfere with the right of everybody to make reasonable contracts. Whenever one sells a business with its good will, it is for his benefit, as well as for the benefit of the purchaser, that he should be able to increase the value of that which he sells by a contract not to set up a new business in competition with the old.' ')

Smith's Appeal, 113 Pa. St. 579, 590, 6 Atl. 251 (1886). ("The principle is this: Public policy requires that every man shall not be at liberty to deprive himself or the State of his labor, skill or talent, by any contract that he enters into. On the other hand, public policy requires that when a man has, by skill or by any other means, obtained something which he wants to sell, he should be at liberty to sell it in the most advantageous way in the market; and in order to enable him to sell it, it is necessary that he should be able to preclude himself from entering into competition with the purchaser."')

Trenton Potteries Co. v. Oliphant, 58 N. J. Eq. 507, 514, 43 Atl. 723 (1899) [161]. ("A tradesman, for example, who has engaged in a manufacturing business and has pur- 
857. Second, there is the use of the combination as a means of eliminating ruinous competition. Competition in trade and industry is constantly inimical to the public interest in two respects: It tends to develop too much competition and consequent loss to everyone in the business. ${ }^{21}$ Too much competition

chased land, installed a plant, and acquired a trade connection and good will thereby, may sell his prop. erty and business with its good will. It is of public interest that he shall be able to make such a sale at a fair price and that his purchaser shall be able to obtain by his purchase that which he desired to buy. Ob. viously, the only practical mode of accomplishing that purpose is by the vendor's contracting for some restraint upon his acts, preventing him from engaging in the same busi. ness in competition with that which he has sold.") Kellogg v. Larkin, 3 Pinney (Wis.) 123 (1851) [142]. 21-Leslie v. Lorillard, $110 \mathrm{~N}$. Y. 519, 534, 18 N. E. 363 (1888) [65]. ("I do not think that competition is invariably a public benefaction; for it may be carried on to such a degree as to become a general evil.")

Oakdale Mfg. Co. v. Garst, 18 R. I. 484, 487, 28 Atl. 973 (1894) [78]. (Argeement found to have been made on account of " a ruinous competition."')

Wickens v. Evans, 3 Y. \& J. 318, 328 (1829) [84]. (Agreement made in view of the fact that the parties "had sustained great loss and inconvenience by reason of exercising their trade in the same places.")

National Benefit Co. v. Union Hospital Co., 45 Minn. 272, 275, 47 N. W. 806 (1891) [94]. ("'Excessive competition is not now accepted as necessarily conducive to the public good.')

Whitney v. Slayton, 40 Me. 224, 230.231 (1855). ("Whether competition in trade be useful to the public or otherwise, will depend on circumstances. I am rather inclined to believe, that, in this coun. try at least, more evil than good is to be apprehended from encouraging competition among rival tradesmen, or men engaged in commercial con. cerus. There is a tendency, I think, to orerdo trade, and such is the en. terprise and activity of our citizens, that small discouragements will hare no injurious effect, in checking in some degree, a spirit of competi. tion.

"In this country, particularly, such is the facility with which persons are enabled, without capital, to embark in various enterprises, and such the desire to try experiments thercin, that it often turns out, when these experiments have been successful, in some of these undertakings, others will enter into them in such numbers that ruin to most of them so engaged is the consequence. Hence those who retire, and for a proper consideration con. tract with others not to engage in any particular business for a lim. ited time, and in a particular place, bave often, if not generally, been the successful party.")

Chappel v. Brockway, 21 Wend. (N. Y.) 157, 164 (1839). ("Com. petition in business, though gener- 
and the intensity of competitive methods may produce too little competition by eliminating others from the business. The competitive system looks to the operation of economic principles under freedom of action to avoid the evils of each extreme. ${ }^{22}$ The freedom of others to enter the business prevents too little competition; the elimination of some competition from time to time prevents too much. A rule of law which made all sales to competitors, and all combinations of competitors, illegal, would leave the door open wide to an indefinite increase in competition, and at the same time obstruct the healthy lessening of competition. This would promote all the evils of too much competition in order to prevent the evils of too little. It would be a rule which encouraged competition only to require that the status quo of every existing competition be indefinitely retained. The public interest must suffer severely from any such rule. The unsuccessful competitor under it would in most instances be eliminated by a total failure and a maximum loss, instead of

ally beneficial to the public, may be carried to such excess as to become an evil." )

Kellogg v. Larkin, 3 Pinney (Wis.) 123, 150 (1851) [142]. ("I believe universal observation will attest that for the last quarter of a century, competition in trade has caused more individual distress, if not more public injury, than the want of competition.')

Slaughter v. The Thacker Coal \& Coke Co., 55 W. Va. 642, 650, 47 S. E. 247 (1904), per Poffenbarger, dissenting. ("Competition is said to be the life of trade, but undue or excessive competition has been judicially declared hurtful and injurious to the public."')

22-Per Pitney, V. C., in Meredith v. New Jersey Zinc \& Iron Co., 55 N. J. Eq. 211, 221, 37 Atl. 539 (1897) [81]. ("Now, I am unable to find any foundation, either in law or in morals, for the notion that the public have the right to have these private owners of this sort of property continue to do business in competition with each other. No doubt the public has reasonable ground to entertain the hope and expectation that its individual members will generally, in their several struggles to acquire the means of comfortable existence, compete with each other. But such expectation is based entirely upon the exercise of the free will and choice of the individual, and not upon any legal or moral duty to compete, and can never, from the nature of things, become a matter of right on the part of the public against the individual. In fact, the essential quality of that series of acts or course of conduct which we call competition is that it shall be the result of the free choice of the individual, and not of any legal or moral obligation or duty.'") Diamond Match Co. v. Roeber, 106 N. Y. 473,13 N. E. 19 (1887) [55], supra. 
having a chance to save his loss by selling out to, or combining with, a more successful rival. Where the competitors were evenly matched all would be subjected indefinitely to a profitless competition or a maximum loss, instead of being permitted to combine and rescue their properties. Industrial depression, due to overproduction and to too many competitors, would necessarily right itself slowly and with a maximum of failures and losses..23

\$ 58. Third, it can hardly be contended that mere combination and elimination of competition between the units combined creates exorbitant prices. What is the judicial test of an exorbitant or unreasonable price? There seems to have been an inpression not entirely wanting in the judiciary that any rise in prices which follows a combination must be unreasonable. This is a shortsighted view. A moment's reflection should make it elear that general condemnation of advances in prices ultimately affects everyone unfavorably. It is equivalent to a general condemnation of prosperity. It is not the advance in prices which is objectionable, but only the unreasonable and exeessive advance. In determining what prices are unreasonably high, are the courts to go into cost accounting and then add a pereentage of profit and reach a specific finding as to what is an unreasonable price in any business under consideration? Obviously not. Such a course would be absurd and impracticable. The courts must find a workable and practicable general rule, the application of which will provide a wide margin of freedom to the business unit and a chance for the exceptional rewards which come from successful management. This leaves the courts no choice except to rely upon freedom to enter the business and frcedom to continue in the business as the means of preventing excessive prices. ${ }^{24}$

23-Oakdale Manufacturing Co. v. Garst, 18 R. I. 484, 487, 28 Atl. 973 (1894) [78]. ("But it does not follow that every combination in trade, even though such combination may havo the effect to diminish the number of competitors in business, is therefore illegal. Such a rule would produce greater public injury than that which it would seek to cure.")
24-Dolph v. Troy Laundry Machinery Co., 28 Fed. 553, 555 (1886). ("Those who might be unwilling to pay the prices asked by the parties could find plenty of mechanics to make such machines, and the law of demand and supply would effectually counteract any serious mischief likely to arise from the attempt of the parties to get exorbitant prices for their machines. 
On the other hand they must allow combination to some extent to prevent unprofitable prices and ruinous competition. The highest price which can be obtained while the business is free to all to enter and no one in it occupies, as a result of combination, a preponderant position, must be taken by the courts as fair. The fact that prices are higher than they were as a result of some combination which eliminates some competition, does not make those prices exorbitant.

\$59. Finally, and most important of all, is the interest of society in the carrying on of business by larger units. This is not only favored by public policy, but it is a condition to the existence of our present social order. It is as vital to the welfare of the country as that freedom of contract-freedom of the managers of business to manage without interference from the legislature-which the due process clause of the Constitution protects. ${ }^{25}$ In the last century one of the phases of our industrial revolution has been the shift from small to large business units. In a cen-

It is quite legitimate for any trader to obtain the highest price he ean for any commodity in which he deals. It is equally legitimate for two rival manufacturers or traders to agree upon a seale of selling prices for their goods, and a division of their profits. It is not obnoxious to good morals, or to the rights of the public, that two rival traders agree to consolidate their concerns, and that one shall discontinue business, and become a partner with the other, for a specified term. It may happen, as the result of such an arrangement, that the public have to pay more for the commodities in which the parties deal; but the public are not obliged to buy of them. Certainly, the public have no right to complain, so long as the transaction falls short of a conspiracy between the parties to control prices by creating a monopoly.")

United States v. Nelson, 52 Fed. 646, 647 (1892). ("Unless the agreement involves an absorption of the entire traffic in lumber, and is entered into for the purpose of obtaining the entire control of it with the object of extortion, it is not objectionable to the statute, in my opinion. Competition is not stifled by such an agreement, and other dealers would soon force the parties to the agreement to sell at the market price, or a reasonable price, at least."')

Slaughter v. The Thacker Coal Co., 55 W. Va. $642,649,47$ S. E. 247 (1904), per Poffenbargex, Pres. ("In the absence of some great combination, virtually controlling the production and price of a commodity in the country, the price is regulated and determined by the law of supply and demand." )

25-“' 'Due Process,' the Inarticulate Major Premise, and the Adamson Act," 26 Yale L. J. 519, (May, 1917). 
tury individuals have been succeeded by partnerships, partnerships by corporations, corporations of small or limited capital by corporations with large capital. Acts which limited corporate capital have been succeeded by acts which place no limit upon the amount of capital. Acts which placed obstructions in the way of increasing capital have been succeeded in some states by acts which allow the corporation to increase its capital stock at will. The large corporation has been succeeded by the parent company which has already been allowed in some states to hold stock controls in subsidiary corporations. If we look at industry and commerce from the outward physical point of view, it is plain that the admittedly legal operating unit of today is, in every line, incredibly large in comparison with the unit of half a century ago. When we turn to the labor units we find the same process going on of shifting from the individual to the collective unit. The individual labor units have been combined to make the local unions, local unions have becn combined to make the statewide and country-wide labor units. Unions have been combined not only locally, and nationally, according to occupation, but territorially without regard to occupation. As one looks back upon what has been going on there can be no doubt that the social order has shifted from a primitive dependence upon the individual industrial unit to the collective unit, and then to the larger collective unit, and that the size of our industrial units has been magnified to an extraordinary degree. A very slight consideration of the matter makes it clear that to put commerce and industry back into the units of fifty, or even twenty-five years ago, would be to disrupt business and do an incalculable harm to the public welfare. Clearly, then, we may rely upon a strong public policy in favor of the shift from the individual and small collective unit to the larger collective unit. ${ }^{26}$

26-Jones v. Clifford's Ex'r, 5 Fla. 510, 515 (1854). ("Associations are 80 common an element, not only in commerce, but in all the affairs of life, that it would be rather perilous on the part of the Court, to assert that they impair competition, destroy emulation and diminish exertion. There is scarcely an occupation in life, scarcely a branch of trade, from the very largest to the smallest, that does not feel the exciting and invigorating influence of this wonderful instrumentality. It made and conducts our government, constructs our railroads, our steam vessels, our magnificent ships, our temples of 


\section{SECTION 3}

COMBINATIONS WHICH HAVE A PREPONDERANT POSITION BUT NO EXCLUDING PURPOSES OR PRACTICES

§60. Suppose now that we have, in a business normally free, a combination which on the one hand has no intent to exclude others from the business and is guilty of no unlawful or unfair excluding practices, but which, on the other hand, "embraces units which together occupy a preponderant position in a given industry." Is this a good trust or a bad trust? Is it illegal at common law, and, if interstate commerce be involved, under the Sherman Act?

\$61. Even if we assume that when the Sherman Act refers to combinations "in restraint of trade" or attempts to monopolize, it refers to such combinations as were illegal at common law because they restrained trade or were attempts to monopolize ${ }^{27}$ we do not get very far, because the common law, while it was clear about some results, gave no unequivocal answer to the problem now under consideration. Even if common-law authori-

worship, structures for public and private use, our manufactories, creates our institutions for learning, builds up our eities and towns.

"Its very office is to do what individual exertion may not accomplish, and in a degree distinguishes eivilized from savage life. Why then should this important agency be denied to this meritorious class of our eitizens? They are in general men of small means, to whom an association may not only be desirable, but necessary and indispen. sable.")

27-Post §§ 108 et seq. Standard Oil Co. v. United States, 221 U. S. 1 (1900) [780, 1072]. (After insisting "that some standard should be resorted to for the purpose of determining whether the prohibition contained in the statute had or had not in any given ease been vio- lated," the opinion of the cotrt proceeds as follows (p. 60): "Thus not specifying, but indubitably contemplating and requiring a standard, it follows that it was intended that the standard of reason which had been applied at the common law and in this country in dealing with subjects of the character embraced by the statute was intended to be the measure used for the purpose of determining whether, in a given case, a particular act had or had not brought about the wrong against which the statute provided." Again the court says (p. 62) "6. . . the criteria to be resorted to in any given case for the purpose of ascertaining whether violations of the section have been committed is the rule of reason guided by the established law, etc. . . ") 
ties be found dealing with the point, nevertheless the Supreme Court of the United States is still entitled to declare for itself what the common law may be as a preliminary to applying the Sherman Act. ${ }^{28}$ Hence the determination of the result in the case put will depend (apart from the question of whether interstate commerce is affected) upon eonsiderations quite as much at large as if the case were being considered at common law for the first time.

\$62. The solution of our problem is to be attained by balancing the interests of the public and the parties involved. ${ }^{29}$ In support of the legality of the combination is the public policy in favor of freedom to manage and carry on business, the elimination of ruinous competition, and the development of larger collective units. Against the legality of the combination is the tendency toward monopoly in the fact that competition between the units combined is eliminated. This, however, is minimized by the fact that there are no excluding purposes or unlawful or unfair cxeluding practices, and the field is free. Apart from the fact of size and preponderant position in the business the balance of interests is clearly in favor of the combination. The entire question is whether that balance is still maintained when we add the fact that the combination has a preponderant position in the business.

Three courses are open to the courts: First, they may hold the fact of size and preponderant position in the industry to be, in and of itself, sufficient to turn the balance against the validity of the combination. This will mean that there can be no good or bad trusts. All trusts, in the sense of large combinations or aggregations of capital, occupving a preponderant position in the business, would be bad trusts. No other combinations would properly be ealled trusts. Second, the courts, on the other hand, might regard the fact of size and preponderant position as insuf-

28-Thus in Dr. Miles Medical Co. v. Park \& Sons Co., 220 U. S. 373 (1911) [838], the Supreme Court of the United States decided in effect that the common law forbade such contracts to keep up the prico on resale as were there involved, in spite of the fact that there were common-law decisions by respectable courts to the contrary. See ante 832 , notes 2,3 and 4 . Post 8116.

29-Horwood v. Millar's Timber \& Trading Co., [1917] 1 K. B. 305, $317,318$. 
ficient, in and of itself, to turn the balance of interests against the validity of the combination. This would mean that there might be good and bad trusts. The bad trusts would be those which had the power and the purpose, or used their power, to exclude others by illegal and unfair methods of competition. The others would be good trusts. Third, between these extremes there is an intermediate position. Size and preponderant position may be regarded as prima facie evidence of an intent to exclude others, or to use the power of the combination to effect unlawful and unfair excluding practices,-thus shifting to the combination the burden of going forward with evidence to negative such intent and use of power. In this view there will still be good trusts and bad trusts. The line between them will be drawn at the place where they have the excluding purpose or practice illegal and unfair excluding methods. But size and preponderant position are still given an important effect as prima facie evidence of the excluding intent.

\section{The State of the Authorities}

$\S 63$. As to which of the above mentioned positions the courts have taken, the cases are far from conclusive.

§64. (1) Several have adopted the second view, and sustained the legality of the combination. ${ }^{30}$

30-Trenton Potteries Co. v. Oliphant, 58 N. J. Eq. 507, 43 Atl. 723 (1899) [161]; United States v. Keystone Watch Case Co., 218 Fed. 502, 510 (1915). ("Size does not of itself restrain trade or injure the public; on the contrary, it may increase trade and may benefit the consumer."')

United States v. Prince Line, 220 Fed. 230, 232 (1915). (Agreement between all the shipowners engaged in the same trade as to the number of vessels each should operate, the dates of sailings, exchange of freight between lines, and rates of freight. The court said: "At the time it was formed the parties were in the trade and handled all the trade there was. No one was frozen out by their combination and there was no greater monopoly than existed before."') United States v. United States Steel Corporation, 223 Fed. 55 (1915).

Fonotipia v. Bradley, 171 Fed. 951 (1909) semble, ("Nor is a 'monopoly,' in the sense meant by the statute, merely the complete occupation of a certain field where that occupation does not unfairly exclude other competitors. The fact that a certain person is the only dealer in certain goods may be en. tirely consistent with a free and un. limited opportunity to every other 
865. (2) The third view was one of the grourds of decision in the Standard Oil case ${ }^{31}$ and was clearly announced in the

person to deal in the same goods, and the law of proper demand and supply may result in but one source from which certain things can be secured, without thereby rendering the person supplying these goods liable to the accusation of illegally maintaining a monopoly."')

United States v. Eastman Kodak Co., 226 Fed. 62, 80 (1915). (". . . that the size and raried character of the enterprise do not of themselves constitute a violation of the statute. To this prineiple $I$ assent. There is no limit in this country to the extent to which a business may grow, and the acquisitions of property in the present case, standing alone, would not bo deemed an illegal monopoly; but when such acquisitions are accom. panied by an intent to monopolize and restrain interstate trade by an arbitrary use of the power resulting from a large business to eliminate a weaker competitor, then they no doubt come within the meaning of the statute.")

United States v. American Can Co., 230 Fed. 859, 901 (1916), 234 Fed. 1019 (1916). (The court, though finding the American Can Co. was originally organized with the intent to exclude others, indulged in unlawful excluding practices, yet by reason of the fact that it had for a considerable period had no illegal purposes or used any excluding practices, a dissolution was refused, and the bill merely retained for a possible future action.)

United States v. Nelson, 52 Fed. 646, 647 (1892). ("Unless the agreement involves an absorption of the entire traffic in lumber, and is entered into for the purpose of obtaining the entire control of it with the object of extortion, it is not objectionable to the statute, in $\mathrm{my}$ opinion."')

See also Queen Ins. Co. v. State of Texas, 86 Tex. $250,24 \mathrm{~S}$. W. 397 (1893) [605]. (Combination of fifty-seven foreign insurance corporations doing business in the State of Texas.) Oakdale Mfg. Co. v. Garst, 18 R. I. 484, 28 Atl. 973 (1894) [78]; Skrainka v. Scharringhausen, 8 Mo. App. 522 (1880). 31-Standard Oil Co. v. United States, 221 U. S. 1, 75 (1911) [780, 1072]. In Texas Standard Oil Co. v. Adoue, 83 Tex. $650,19 \mathrm{~s}$. W. 274 (1892), where the combination was held illegal, the court, nevertheless, intimated that under certain circumstances it might appear that the same combination would bo perfectly legal-thus indicating that the inference in favor of illegality arising from the combination's pre. ponderant position in the industry might be rebutted. So in Jones $\mathrm{v}$. Clifford's Ex'r, 5 Fla. 510 (1854), a combination of all the pilots serving a certain port, but merely for the purpose of apportioning their duties and earnings, was sustained. The facts rebutted any inference of an intent to exclude others. In Skrainka จ. Scharringhausen, 22 Mo. App. 522 (1880), any intent to exclude others was rebutted by proof that the combination was necessary in order to stop a ruinous competition and promote the business. 
opinion of the court. In stating the grounds for sustaining the findings and decision of the court below, the supreme court said:

"Because the unification of power and control over petroleum and its products which was the inevitable result of the combining in the New Jersey corporation by the increase of its stock and the transfer to it of the stocks of so many other corporations, aggregating so vast a capital, gives rise, in and of itself, in the absence of countervailing circumstances, to say the least, to the prima facie presumption of intent and purpose to maintain the dominancy over the oil industry, not as a result of normal methods of industrial development, but by new means of combination which were resorted to in order that greater power might be added than would otherwise have arisen had normal methods been followed, the whole with the purpose of excluding others from the trade, and thus centralizing in the combination a perpetual control of the novements of petroleum and its products in the channels of interstate commerce."' 32

Then the court justifies the decree below:

"Because the prima facie presumption of intent to restrain trade, to monopolize and to bring about monopolization, resulting from the act of expanding the stock of the New Jersey corporation, and vesting it with such vast control of the oil industry, is made conclusive, etc. . . .",

A little later the court, in referring to certain facts which were urged as rebutting any monopoly tendency, said:

". . . they miglit well serve to add additional vogency to the presumption of intent to monopolize which we have found arises from the unquestioned proof on other subjects."

\$66. Practically all the cases where the combination has been held illegal at common law or under the Sherman Act, without

32-This is a particularly strong statement, because in the Standard Oil Case the combination attacked and dissolved was the Standard Oil of New Jersey reorganized as a holding company in 1899 . It was not a combination of competing units. The subsidiaries had been non-competing (except perhaps in a few instances not disclosed in the case reported) since a time prior to the passage of the Sherman Act.
It could fairly be said that the units combined in the Standard Oil of New Jersey in 1899 never had competed. Hence, the prima facie evidence of intent to exclude others arose from size and preponderant position in the industry brought about by combination without the suppression of any existing compotition between the units combined. See post $\S \S 127,128$. 
actual proof of any excluding purposes or practices, may be explained consistently with the third view. Thus in the Addyston Pipe case ${ }^{33}$ the facts relied upon by the United States Supreme Court to hold the combination illegal were those quoted from the opinion of Taft, J., in the Circuit Court of Appeals. These disclosed merely a combination occupying a preponderant position in a given market, and effected by a contract which provided for the making of sales, and the fixing of prices by a central authority or committee. It may be assumed that this is a case where size and preponderant position in the business without any excluding purposes or practices, caused the combination to be illegal.s4 Neither the opinion of the Court of Appeals, nor the Supreme Court, in the least discloses whether the preponderant position is, in and of itself, a ground of illegality, or merely prima facie evidence of an excluding purpose to be carried out by illegal excluding practices. The result reached might go upon either ground. Many other cases arc subject to a similar analysis. $^{35}$ So where the competing properties were bought up

33-United States v. Addyston Pipe \& Steel Co., 85 Fed. 271 (1898) [625]; 175 U. S. 211 (1899) [772, $1047]$.

34-Taft, J., in the circuit court of appeals relied upon the illegal practice of the combination in suppressing competitive bidding on municipal contracts. This, the supreme court omitted all reference to, no doubt, upon the ground that if relied upon solely, it would not justify a dissolution of the combination, and if not so relied upon it was unnecessary to mention it at all.

35-Morris Run Coal Co. v. Barclay Coal Co., $68 \mathrm{~Pa}$. St. 173 (1871) [680] (Combination of all the bituminous coal mines in a given district, and all but one at that time open which supplied bituminous coal in a large district); Central Ohio Salt Co. v. Guthrie, 35 Ohio St.
666 (1880) [690] (Combination included all the salt producers in a large salt-producing territory); People v. Sheldon, 139 N. Y. 251, 34 N. E. 785 (1893) [695] (Combination of "all the retail coal dealers in the city of Lockport except one"); Peoplo v. Milk Exchange, 145 N. Y. 267, 272, 39 N. E. 1062 (1895) [707] ("Acting upon these by-laws, the defendant's board of directors have from time to time during its corporate existence fixed the price of milk to be paid by dealers, and the prices so fixed have largely controlled the market in and about the city of New York and of the milk-producing territory contiguous thereto. These facts are significant, and we are unable to escape the conviction that there was a combination on the part of the milk deasers and creamery men in and about the city of New 
and united in a new corporation or board of trustees under the old managers, or under new managers, the size of the combination and its preponderant position in the business caused it to be held illegal. ${ }^{36}$ But whether this result was reached because the size was, in and of itself, a basis for illegality, or because it was only prima facie and unrebutted evidence of an intent to exclude others from the field, is not in the least made plain.

\$67. In a number of cases, it must be conceded, there was lacking direct proof of the preponderant position of the combination in the business. ${ }^{37}$ In the Standard Oil of Ohio case, ${ }^{38}$ the

York to fix and control the price that they should pay for milk"); Cummings v. Union Blue Stone Co., 164 N. Y. 401, 403, 58 N. E. 525 (1900) [712] (Assuming blue stone quarrying and selling to be a business separate from stone quarrying and selling generally, the combination in question was of fifteen producers " of nearly the whole product of Hudson river bluestone, and of at least ninety per centum of the whole amount of such stone sold in the New York market to customers in various states east of the Mississippi river'); Emery v. Ohio Candle Co., 47 Ohio St. 320, 321, 24 N. E. 660 (1890) [716] (Combination of "the manufacturers of 95 per cent of the star candles in that part of the United States lying east of the $114^{\circ}$ of longtitude west of Greenwich, or substantially all the territory east of the western boundary of Utah"); Nester v. Continental Brewing Co., $161 \mathrm{~Pa}$. St. 473, 29 Atl. 102 (1894) (Combination of the forty-five brewers of the county of Philadelphia); Pocahontas Coke Co. v. Powhatan Coal \& Coke Co., 60 W. Va. 508, 56 S. E. 264 (1906) (Combination of twenty coke manufacturing and producing corporations operating in the same field); Milwaukee Masons \& Builders' Ass'n v. Niezerowski, 95 Wis. 129, 70 N. W. 166 (1897) (Combination of "nearly six-sevenths of the mason builders in Milwaukee"); Stanton v. Allen, 5 Denio (N. Y.) 434 (1848) (Combination among the whole, or a large proportion, of the proprietors of boats on the Erie and Oswego canals); Hoffman v. Brooks, 6 Ohio Dec. reprint, 1215 (1884) (Combination of all the tobacco warehousemen in Cincinnati); McBirney \& Johnston White Lead Co. v. Consolidated Lead Co., 8 Ohio Dec. reprint, 762 (1883) (Combination of the white lead manufacturers of the United States west of Buffalo).

36-Chapin v. Brown Bros., 83 Iowa 156, 48 N. W. 1074 (1891) [138]; Distilling \& Cattle Feeding Co. v. People, 156 Ill. 448,41 N. E. 188 (1895); Bishop v. American Preservers' Co., 157 Ill. 284, 41 N. E. 765 (1895); Harding v. American Glucose Co., 182 Ill. 551, $55 \mathrm{~N}$. E. 577 (1899).

37-Judd v. Harrington, 139 N. Y. 105,34 N. E. 790 (1893) [718]; Texas Standard Oil Co. v. Adoue, 83 Tex. 650 (1892); Hooker v. 
record presented consisted of the petition, answer, and demurrer of the state. This record apparently presented no statement of the fact that the units combining in the Standard Oil Trust of 1882 were competing, nor did it disclose what eapital they represented, or whether as combined they occupied a preponderant position in the industry. The eourt evidently took judicial notice of these important facts. It is clear that heretofore at least, courts have not been over particular about requiring records which showed the size and preponderant position of the combination in question. Yet it is not conceivable that these courts were holding illegal every combination however insignificant which eliminated competition between the units combined. ${ }^{39}$ Hence some assumptions about size and preponderant position must be made in all eases where the combination has been held illegal. When such an assumption is made, the courts are absolutely silent as to whether the fact of size and preponderant position is, in and of itself, conclusive of illegality, or merely prima facie evidence of an excluding purpose.

868. (3) Outside of the decision of the District Court in the International Harvester case, ${ }^{40}$ there have been no results and no dicta which clearly announce the first view. It must be conceded, however, that the language of the courts in a number of cases, which are, nevertheless, explainable on the ground that there was a prima facie inference of excluding purposes and practices, sounds as if the court regarded the mere elimination of competition between the units combined as illegal per $s e .^{41}$ So, scattered through cases where there was a clear purpose to exclude others by illegal methods of competition, ${ }^{42}$ or a combi-

Vandewater, 4 Denio (N. Y.) 349 (1847); De Witt Wire-Cloth Co. v. New Jersey Wire-Cloth Co., $14 \mathrm{~N}$. Y. Supp. 277 (1891); Anderson v. Jett, 89 Ky. 375 (1889); Vulcan Powder Co. v. Hercules Powder Co., 96 Cal. 510, 31 Pac. 581 (1892); Ford จ. Chicago Milk Shippers' Ass'n, 155 Ill. 166,39 N. E. 651 (1895); India Bagging Ass'n v. Kock \& Co., 14 La. Ann. 168 (1859); Urmston v. Whitelegg
Bros., 63 L. T. R. (N. S.) 455 (1890).

38-State v. Standard Oil Co., 49 Ohio St. 137, 30 N. E. 279 (1892) [649].

39 -See cases ante \& 53, n. 17, 18. 40-214 Fed. 987 (1914) (now pending on writ of error in the Supreme Court of the United States).

41 -See cases ante $865, \mathrm{n} .35,36$. $42-$ See cases ante 49, n. 6,7 . 
nation of railroads or public service corporătions where the field was not, as a matter of law, free to the public to enter, ${ }^{43}$ or where the problem here discussed was not involved, will be found many general expressions which make it appear as if the court thought mere size in any business was inimical to the public interest. ${ }^{44}$

43-See cases ante $\$ 51$, n. 14.

44-People v. Chicago Gas Trust Co., 130 Ill. $268,303,22$ N. E. 798 (1889) [735]. ("We concur in the following views expressed by the Supreme Court of Georgia in the case of Central R. R. Co. v. Collins, supra, [40 Ga. 582]: 'All experience has shown that large accumulations of property in hands likely to keep it intact for a long period are dangerous to the public weal. Having perpetual sucession, any kind of a corporation has peculiar facilities for such accumulation, and most governments have found it necessary to exercise great caution in their grants of corporate powers. Even religious corporations professing, and in the main, truly, nothing but the general good, have proven obnoxious to this objection, so that in England it was long ago found necessary to restrict them in their powers of acquiring real estate. Freed as such bodies are from the sure bound to the schemes of individuals, - the grave,- they are able to add field to field, and power to power, until they become entirely too strong for that society which is made up of those whose plans are limited by a single life.' ')

Woodberry v. MeClurg, 78 Miss. 831, 835, 29 So. 514, 515 (1901). (In holding an attempt at power in a corporation to purchase stock in other corporations not competing with it, the court said: "That the powers attempted to be lodged in the Laurel Gravel Company would be illegal, if granted, we cannot doubt. They would make it a stupendous monster, capable of swallowing into its insatiable maw all the mercantile and manufacturing institutions of the entire country, because none of them would be in any competition with it in the gravel business.'")

Richardson v. Buhl, 77 Mich. 632, 658, 43 N. W. 1102 (1889). ("'Indeed, it is doubtful if free government can long exist in a country where such enormous amounts of money are allowed to be accumulated in the vaults of corporations, to be used at discretion in controlling the property and business of the country against the interest of the public and that of the people, for the personal gain and aggrandizement of a few individuals." )

State v. Standard Oil Co., 49 Ohio St. 137, 187, 30 N. E. 279 (1892) [649]. ("A society in which a few men are the employers and the great body are merely employees or servants, is not the most desirable in a republic; and it should be as much the policy of the laws to multiply the numbers engaged in independent pursuits or in the profits of production as to cheapen the price to the consumer. Such policy would tend to an equality of fortunes among its citizens, thought to be so desirable in a republic, and lessen the amount of pauperism and crime."') 
One reason for such expressions is now fairly clear. They were made for the most part in the '80s and '90s. That was a time when the process of shifting from smaller units to larger and still larger units was carried on with extraordinary rapidity and persistence. The power which came from the sudden combination was new and uncontrolled by those who possessed it. It had been, and was being, terribly abused. Unlawful exclud-

United States v. Trans-Missouri Freight Ass'n, 166 U. S. 290, 324 (1896) [862]. (". . . it is not for the real prosperity of any country that such changes should occur which result in transferring an independent business man, the head of his establishment, small though it might be, into a mero servant or agent of a corporation for selling the commodities which he once manufactured or dealt in, having no voice in shaping the business policy of the company and bound to obey orders issued by others." )

Similar expressions occurred in the debate preceding the passage of the Sherman Act:

United States v. Trans-Missouri Freight Ass'n, 166 U. S. 290, 319 (1896) [862]. (The court, referring to these debates, said: "Among these trusts it was said in Congress were the Beef Trust, the Standard Oil Trust, the Steel Trust, the Barbed Fence Wire Trust, the Sugar Trust, the Cordage Trust, the Cotton Seed Oil Trust, the Whisky Trust and many others, and these trusts it was stated had assumed an importance and had acquired a power which were dangerous to the whole country, and that their existence was directly antagonistic to its peace and prosperity."

Senator Sherman, opening the debate upon the Sherman Act, said (21 Cong. Rec. 2457): “But associated enterprise and capital are not satisfied wtih partnerships and corporations competing with each other, and have invented a new form of combination, commonly called trusts, that seeks to avoid competition by combining the controlling corporations, partnerships, and individuals engaged in the same business, and placing the power and property of the combination under the gorernment of a few individuals, and often under the control of a single man called a trustce, a chairman, or a president. . .

"Such a combination is far more dangerous than any heretofore invented, and, when it embraces the great body of all the corporations engaged in a particular industry in all of the states of the Union, it tends to advance the price to the consumer of any article produced, it is a substantial monopoly injurious to the public, and, by the rule of both the common and eivil law, is null and roid and the just subject of restraint by the courts, of forfeiture of corporate rights and privileges, and in some cases should be denounced as a crime, and the individuals engaged in it should be punished as criminals. It is this kind of a combination we have to deal with now."

Kales Bum. R. of T.-5 
ing practices were the regular accompaniment of combinations which occupied a preponderant position in the business. The consequence was that all such combinations received a bad nanue. Combination was, in and of itself, regarded as dangerous and contrary to the interests of society. Furthermore, the courts did not at all appreciate that they could draw a sharp line between combinations which had the excluding purpose and used unlawful excluding practices and those which did not. They did not at all perceive that size and preponderant position in the business might be made, in and of itself, prima facie evidence of the intent to exclude by the use of unlawful excluding practices and thus require the combination to meet that ease against it. In the face of the unlawful use of the power of combinations and the profound obscurity as to where the line was to be drawn against them, it is not to be wondered at that courts, while reaching sound results, should have stressed and fulminated against combinations as such, and looked upon size as something inherently reprehensible. But even so, it is apparent that these same courts made no conscious decision between the rule that size and preponderant position were, per se, illegal, and the rule which made them merely prima facie evidence of an intent to exclude others by unlawful means. The latter view is entirely consistent with the fear of size in combination though not always with the heat with which that fear is expressed.

\$69. It should be observed also that the concession of the District Court in the International Harvester Case ${ }^{45}$ that "there is no limit under the American law to which a business may not independently grow," is difficult to reconcile with the proposition that mere size and preponderant position is, in and of itself, illegal. It is useless to insist that mere growth is normal and combination abnormal. Both are normal methods of growth. Combination is normal up to a certain point so long as it is legal. No advance is made by saying it is abnormal because it is illegal, when its abnormality is in turn used to prove its illegality. If size is a menace in the case of growth by combination it is a menace where there is growth without combination. How the growth may occur is immaterial. On the other hand, if size and pre- 
ponderant position in the business are by themselves not a test of illegality, but only evidence of the excluding purpose, then we may fairly make a difference between independent and normal growth (so called) and combination. The former might properly furnish no prima facie evidence of the excluding pur. pose. The latter would.

\$70. It is generally assumed that an agreement between competitors, together occupying a preponderant position in the business, that they will maintain a fixed price or a fixed minimum price at least, is illegal.46 From this it has been argued that a mere combination of competing properties under one management without any agreement amounted to the same thing, and hence was, in and of itself, illegal.47 The fallacy here is twofold. It is assumed that the fixing of the price is, in and of itself, illegal, when it may just as well be merely prima facie evidence of an assumption of the control of the market, and the purpose to exclude others. Indeed, the contract to maintain a certain price for any considerable period would hardly be sensible except upon these assumptions. But even if price-fixing agreements are, in and of themselves, illegal, it does not follow that the mere combination of the same units is, in and of itself, illegal. The vice of the price-fixing agreement is not merely the elimination of competition between the units. It is the assumption of the fact that the field of the business will not be free to others to enter, and the necessary inference from such an assumption that those combining have control of the market and intend to use their power to keep it. This may be so clear from the actual agrec-

46-Urmston v. Whitelegg Bros., 63 L. T. R. (N. S.) 455 (1890). It should be observed that it is diff. cult to find cases of this sort, for the reason that most of the contracts provide for the fixing of prices from time to time by a cen. tral authority.

47-Opinion of the majority of the District Court in United States v. International Harvester Co., 214 Fed. 987, 999 (1914). ("We think it may be laid down as a general rule that if companies could not make a legal contract as to prices or as to collateral services they could not legally unite, and as the companies named did in effeet unite the sole question is as to whether they would have agreed on prices and what collateral services they could render, when their companies were all prosperous and they jointly controlled eighty to eighty-five per cent of the business in that line in the United States. We think they could not have made such an agreement.' Italics ours.) 
ment that it is conclusive. When, however, the units combine without any agreement, the size and preponderant position of the combination in the business may be such as, prima facie to raise the inference that there is a purpose to exclude others and to use excluding practices. But there is nothing in any solemn agreement of the parties which in so many words declares that purpose. Hence the inference is rebuttable.

§71. The Dr. Miles Medical Co. Case ${ }^{48}$ clearly goes upon the ground that there was involved a combination of the manufacturer and distributing retailers which eliminated all competition between the retailers and maintained retail prices by agreement. It made no difference that the agreements which effected these objects were between the manufacturer and the retailers. The result was the same as if they had been between the retailers themselves. The combination by agreement, therefore, assumed a command of the market, so far as the articles sold were concerned, and the fixing of prices assumed that, with the aid of the manufacturer, all others could be excluded from the retail business, and all competition between the retailers in the combination suppressed. The holding of such a scheme illegal, whether rightly or wrongly, ${ }^{49}$ does not in the least support the general proposition that mere elimination of competition by combining properties under a new management, or combining properties and managers in a new industrial unit is, in and of itself, illegal. This is clear, because the court itself tacitly conceded the point made by $\mathrm{Mr}$. Justice Holmes in his dissenting opinion that if title to the goods did not pass, and the retailers were mere agents of the manufacturer, the same restrictions as to price would be valid. ${ }^{50}$ But that would have been just as much an elimination of competition between retailers as existed already, and if such

48-Dr. Miles Medical Co. v. Park \& Sons Co., 220 U. S. 373 (1911) [838].

49-Ante $\$ \& 31-39$.

$50-$ Nor is this position weakened by the recent decision in Straus v. Victor Talking Machine Co., 243 U. S. 490 (1917). The licenses there involved provided for the use of a patented article with a restraint as to the selling price. The restraint was held void because the license was, under all the circumstances, a mere subterfuge for a sale. But an agency to distribute a manufacturer's goods may be a reality, and if so the principal may certainly control the price at which his distributing agent shall sell. 
an elimination of competition be illegal per se, the form would be immaterial. It is clear, therefore, that the illegality of the combination in question arose from the price-fixing arrangement and a control of the market by excluding others which it was supposed such an arrangement assumed, and not merely from the elimination of competition between the retailers.

872. (4) It is important to observe that in drawing the line between good and bad labor organizations, the courts have been quick to approve combinations among labor units no matter what the size or preponderant position of the union may be, up to the point where the combination has unlawful and excluding purposes or indulges in unlawful excluding practices, so that the labor market is no longer free to other labor units or to employers. Every labor union eliminates competition betwcen the units combined, and while there may be no agreement as to price, they all have the purpose to secure as high wages as possible. They are not, however, illegal for that reason. ${ }^{51}$ The interest of society in the frecdom of men to combine to better their situation by eliminating too much competition and the doing of business by larger collective units ovcrcomes any interest of the public in having unrestricted competition among labor units. But let the labor union acquire the purpose of excluding all others except its members from the labor market, or let the union commence unlawful or unfair excluding practices and methods so as to make the labor market unfree, and the organization becomes illegal at common law, 52 and, if interstate commerce is involved, under the Sherman Act. That is the only line attcmpted. No court has suggested that the mere size of a union or its preponderant position in the labor market makes it, per se, illegal. It has not even been suggested that size and preponderant position is prima facie evidence of an intent to exclude others or to indulge in excluding practices. This is significant because such

51-The Master Stevedores' Ass'n v. Walsh, 2 Daly (N. Y.) 1 (1867) [388]; Snow v. Wheeler, 113 Mass. 179 (1873) [400]; Thomas v. Cincinnati, N. O. \& T. P. Ry. Co., 62 Fed. 863 (1894) [407] (per Taft, Circuit Judge); contra,
Hornby v. Close, L. R. 2 Q. B. 153 (1867) [278], not followed. See Collins v. Locke, L. R. 4 A. C. 674 (1879) [298].

52-People v. Fisher, 14 Wend. (N. Y.) 9 (1835). 
excluding purposes and practices are quite as likely to follow from the acquisition by a union of a preponderant position in a given labor market as they are from the acquisition of a similar position in industry by the owners or managers of combined properties. More than one court has noted that, so far as the legality of combinations is concerned, combinations of property, or property and managers, are on the same footing as combinations of labor units. ${ }^{53}$ No difference has been pointed out by anyone. If there is any difference based upon the different standing of labor units to unite and managing units controlling property to unite, it would be entirely satisfied by permitting the labor units to combine to any extent without such combination giving rise to any prima facie inference of an intent to exclude others, while, at the same time, a combination of managing and property units occupying a preponderant position in the business, would necessarily give rise to such a prima facie inference and' must sustain the burden of meeting the case so made against it.

§73. (5) Our view of the state of the authorities should not be concluded without considering the relation between a certain class of cases arising under the "due process" clause and under the Sherman Act. Suppose in cases where the question is whether an act of the legislature is "due process" which interferes with the management of business' by prescribing hours of labor or methods of payment of wages or the amount of wages, four judges out of nine are clear that the fundamentals of the social order are in jeopardy, and the act must be set aside. When these same judges come to draft or approve a judicial rule proscribing business organizations as illegal, they would consistently with their views on "due process" be inclined to impose only such restraint as seemed clearly to be called for to meet an undoubted

53-Queen Ins. Co. v. State of Texas, 86 Tex. 250, 271, 24 S. W. 397 (1893) [605]. ("It follows, therefore, that if insurance companies are to be brought within the rule that makes agreements to in. crease the price of merchandise illegal, upon the ground that the public have an interest in their business, agreements among laborers and among professional men not to render services below a stipulated rate should be held contrary to public policy and void upon the same ground"); Sayre v. Louisville Union Benevolent Ass'n, 1 Duvall (Ky.) 143 (1863) (semble). 
evil-having in mind always the limits of such a judicial prohibition, and the avoidance of any rule founded upon doubtful or speculative economic data or results. Such judges might be expected to adopt as the test of illegality the existence of the excluding purposes or illegal excluding practices. Suppose in the same "due process" cases five judges are inclined to sustain the act. Three go upon a social bias in favor of the legislative restriction upon business. That is, upon balancing the interests, they regard the restriction upon business as for the general welfare. Two, however, if they exercised independent judgment in balancing the interests, would have regarded the legislation as opposed to the general welfare and inimical to the social order in accordance with the views of the minority. But they have felt bound to sustain the act in accordance with the rule that it must be upheld if any rational basis for it can be found after resolving all doubts in favor of the act. The moment these two come to consider the test of legality of business organizations they are released at once from the obligation of sustaining anything, if a rational basis can be found for it. With regard to a judge-made rule prohibiting certain business organizations, they are not only free to balance the interests for and against the prohibition involved, but they are subject to a counsel of caution that, when in doubt, they shall not extend the prohibition, but restrict it to cover only that generality of situations where the public interest is indubitably affected unfavorably.

\section{Economic Effect of Mere Size}

874. In $1911 \mathrm{Mr}$. Brandeis in testifying before the Senate Committee, ${ }^{54}$ said :55

"You may have an organization in the community which is so powerful that in a particular branch of the trade it may dominate by mere size. Although its individual practices may be according to rules, it may bo, nevertheless, a menace to the community; . . ."

54-Reference is here and in succeeding paragraphs made to the testimony of Louis D. Brandeis before the Committee on Interstate Commerce of the United States Benate, 62d Congress. It was given on December 14, 15, 16, 1911. Mr. Brandeis is referred to in the capacity in which he testified.

55-Report of hearing before Senate Committee on Interstate Commerce, supra, 1146. 
Mr. Brandeis' experience and authority have been so great, and his views before the Senate Committee are expressed so fully and frankly, that it is worth considerable trouble to ascertain just what were the grounds for this opinion, and how far they may require a holding by a court that mere size is, in and of itself, illegal, rather than prima facie evidence of illegal excluding purposes and practices.

§ 75. (1) It is clear from Mr. Brandeis' testimony that he does not condemn mere size because it, in and of itself alone, tends to exclude others from the business. The main thesis of his testimony is that size-and he is referring particularly to the size of our so-called American trusts-results in such economic inefficiency that without any excluding practices and purposes they must fail, or at least lose their relative position in the market by reason of successful competition carried on by smaller and more efficient units. His language to this effect is so strong and to the point that it should be read. After setting out the records of certain trusts, ${ }^{56}$ he says :

"I believe that the existing trusts have acquired the position which they hold largely through methods which are in and of themselves repre-

56-Report of hearing before the Senate Committee on Interstate Commerce, supra, 1148: "Now, that mere size does not bring effciency, does not produce success, appears very clearly when you examine the records of the trusts.

"In the first place, most of the trusts which did not secure a domination of the industry-that is, the trusts that had the quality of size, but lacked the position of control of the industry, lacked the ability to control prices-have either failed or have shown no marked success. The record of the unsuccessful trusts is doubtless in all your minds. One of the earliest of the trusts which did not secure control was the Whisky Trust. It was not successful. The plight of the Cordage Trust and of the Malting
Trust was worse. Consider other trusts now existing, the Print Papers Trust (the International Paper Co.); the Writing-Paper Trust (the American Writing-Paper Co.); the Upper Leather Trust (the American Hide \& Leather Co.); the Union Bag Trust, the Sole Leather Trust; those trusts and a great number of others which did not attain a monopoly and were therefore unable to fix prices have had but slight success as compared with their competitors. You will find daily evidence of their lack of success in market quotations of the common stock, where they are quoted at all, and the common stock of some has even fallen below the horizon of a quotation.

"Now take, in the second place, the trusts that have been markedly 
hensible. I mean either through methods which are abuses of competition or by such methods as were pursued by the steel corporation in pay. ing ridiculous values for property for the purpose of monopolistic control.

successful, like the Standard Oil Trust, the Shoe Machinery Trust, the Tobacco Trust. They have succeeded throngh their monopolistic position. They dominated the trade and were able to fix the prices at which articles should be sold. To this monopolistic power, in the main, and not to efficiency in management, are their great profits to bo ascribed.

"Leaving the realm of industry for that of transportation, compare the failure of Mr. J. P. Morgan's creation-the International $\mathbf{M e r}$ cantile Marino-and the astonishing success of the Pullman Car Co. The transatlantic steamship trade was open to competition, and could not, in spite of its price agreements, fix rates at an elevation sufficient to be remunerative. The Pullman Co., possessing an absolute monopoly, has made profits so large as to be deemed unconscionable.

"In the third place, take the class of cases where the trust has not controlled the market alone, but ex. erted control only through virtue of price agreements or understandings, as did the Sugar Trust and the Steel Trust. Those trusts paid large dividends, because they were able to fix remunerative prices for the product. Bnt neither the Sugar Trust nor the Steel Trust has been able to hold its own against its competitors.

"Take it in the Sugar Trust. At the time of the Knight Case, a little less than twenty years ago, the Sugar Trust had practically the whole business of the country-I think the supreme court report shows something like 95 per cent. The company's reports to the stockholders of 1910, as I recall it, show that the company now controls only 42 per cent of the production of the country.

"The price agreements or understandings between the trust and its competitors had maintained the price, but they could not maintain for the trust its proportion of the business. The Sugar Trust's profits were maintained, as you so well know, not only through the price agreements, but through methods that were vulgarly criminal through false weighing; through stealing of city water; through extensive railroad rebating.

"Then take the Steel Trustthat is a younger trust, only half the length of life of the Sugar Trust. But in the Steel Trust you have a similar manifestation of ebbing prestige. In spito of all this extraordinary power in the Steel Trust, the control of raw material, the control of transportation, the control of certain trade through its railroad associations, the control of other trade through its money power-and the addition of the Tennessee Coal \& Iron Co.in epite of all this the Steel Trust has been a steady loser in percentage of the iron and steel busi. ness of this country. And not only has it been a steady loser in the percentage of business in this country, but despito its ability to largely maintain prices, notably of steel rails, throughout that period, the later years show a diminishing 
"I am so firmly convinced that the large unit is not as efficient-I mean the very large unit-is not as efficient as the smaller unit, that $I$ believe if it were possible today to make the corporations act in accordance with what doubtless all of us would agree should be the rules of trade no huge corporation would be created, or, if created, would be successful. I do not mean by that to say that it is not good to have the limitation [on size] in the law. What I mean is that I am so convinced of the economic fallacy in the huge unit that if we make competition possible, if we create conditions where there could be reasonable competition, that these monsters would fall to the ground, that $I$ do not consider the need of such a limitation urgent."' 57

It is quite obvious that the so-called trust cannot at the same time exclude others because of its size, and fail or decline by reason of the successful competition of others for the same reason. It cannot be that mere size alone tends to exclude others, and that size results in such inefficiency that others are able to enter the business easily and compete successfully. One or the other of these results must be discarded on the ground of inconsistency. As Mr. Brandeis' main thesis was that size breeds inefficiency and failure in the competitive struggle, it is fair to say that he does not place the "menace" of the trust which has no excluding purposes, and uses no excluding practices, upon the fact that mere size alone tends to exclude others. He would not argue that it was the usual effect of mere size to "overawe" the smaller competitor,, 58 or to "make men hesitate to enter the field against it," or "to prevent the entrance of new capital and new competition into the industry." 59

876. (2) It has been urged that if five plants are supplying a given trade, the union of those plants tends to exclude others, because there will be no chance for anyone else to supply a demand which is already being adequately served.60 This exhibits

return upon the capital invested as compared with the earlier years of the trust."

57-Report of hearing before the Senate Committee on Interstate Commerce, supra, 1170. Ttalies ours.

58-Brief of Government in International Harvester Co. v. United States (now pending in the Su- preme Court of the United States), 88.

59-Ibid.

60-Senator Sherman's speech, opening the debate on the Sherman Anti-Trust Act, 21 Cong. Rec. 2460. ("But, they say, competition is open to all; if you do not like our prices, establish another combination or trust. As was said by the 
a child-like power of reasoning as to economic effect. Mr. Brandeis, of course, made no such point. His main thesis, that size was so inconsistent with efficiency that a trust without any excluding purposes or practices was an easy mark for independent competition is utterly inconsistent with the contention that when all the units in a given business have combined, there is no room for anyone else.

\$ 77. (3) Mr. Brandeis does suggest ${ }^{61}$ that "the mere power of endurance of the large company would be sufficient to give it mastery of the field." He was spcaking at the time of the tobacco trust. The context is as follows:

"I found, for instance, in the tobacco company this situstion-and it was one of the many objections to the plan of so-called disintegrationthat the American Tobacco $\mathrm{Co}$. in various departments were controlling about 40 per cent or over of the American business. Wo found there that in this way the American Tobacco Co. alone, and each one of the other two large companies, would control a proportion of the total business of the country in certain departments of the trade which was from one to seven times the aggregate of the business of all of the independents. Now, I believe that fair competition is not possible under those conditions, because the mere power of endurance of the large company would be sufficient to give it mastery of the field."

The purport of this is somewhat vague. If excluding practices are used, or if from the mere size of the tobacco company units which were provided for in the disintegration plan referred to, there was still a prima facie inference that excluding practices would be used, then of course the "trust" would have a "power of endurance" which would keep out its competitors, and give it a mastery of the field. This is probably Mr. Brandeis' meaning, for his main thesis is that mere size without excluding purposes or practices is a source of economic weakness and operates to give competitors an advantage based on efficiency. This is entirely inconsistent with the view that mere size produces any mastery of the field. Others, however, may insist that the resources

Supreme Court of New York [People v. North River Sugar Refining Co., 54 Hun (N. Y.) 354, 377], when the combination already includes all or nearly all the producers, what room is there for another?")
61-Report of hearing before the Senate Committee on Interstate Commerce, supra, 1175. Italics ours. 
of a so-called trust are so great that the combination could practice universal price-cutting below cost in order to destroy all rivals and exclude others. The reserves, however, of such an organization are not necessarily proportionately larger than those of smaller units. It may fairly be denied that there are any such resources in the hands of a so-called trust as will enable it to keep up universal price-cutting below cost on a country-wide basis longer than a smaler unit can keep up the same price-cutting in the smaller field where it operates. Of course, no court can deal with the question of legality on the fortuitous basis of what proportion of reserve capital one corporation may liave in comparison with that of its rival or possible rival. Even if one could imagine a trust punishing itself by universal price-cutting to the extent assumed, how is the public injured? Surely not by the introduction of prices so low that no one cares to enter the business or to stay in the business and the retention of such prices in general whenever any competitor appeared in any part of the country.

§ 78. (4) Perhaps it will be said that the large combination will absorb all the best talent in the community for the business, and so make competition impossible. This position, however, is equally inconsistent with $\mathrm{Mr}$. Brandeis' main thesis. If such were the fact, then the "trusts" would not fail for inefficiency or be subject to successful competition from new capital. Furthermore, there will still be infinite dispute as to whether the "trust" does, in fact, secure the best talent. If the subject were investigated able men could no doubt be found to testify that the more progressive and inventive minds arise among the independent smaller units, and that the large unit tends to conservative methods, lack of initiative, and want of inventive powerindeed, that it is subject to all the evils of a bureaucracy. For instance, between the independent telephone engineers and inventors and the engineers and inventors of the Bell system will be found a long standing dispute as to the merits and abilities of the men in each group. Furthermore, it may well be doubted whether efficiency and experience can be regarded as limited to any such degree that it can be "cornered." 62

62-Thus Mr. Justice Day, sitting as a Justice in the circuit court of appeals in the Cash Register Case, 222 Fed. 599, 619 (1915), observed 
879. (5) Combination resulting in a unit occupying a preponderant position in the business has been objected to because it tends unduly to enhance prices. The idea is that there is a necessary connection between size and high prices. This rests, of course, upon the belief that there is a necessary connection between mere size (without any excluding purposes or practices) and the exclusion of others from the business. When the latter is exploded, does anything remain of the former? Any idea that there is a necessary connection must certainly be abandoned. It is significant that when Mr. Brandeis was asked whether he would regard 15 per cent return on $\$ 10,000,000$ of capital an extortionate profit, he not only refused any percentage as a test of fair profit, but plainly indicated that the only test of extortionate prices which he had in mind was the fact that the market was unfree; -in short, that the unit fixing the prices had the excluding purpose and used unlawful excluding practices. He said : ${ }^{03}$ [Italies ours]

"In a business which is a competitive business, I believe we can safely leave the percentage of profit to that which the business will bear, and I think it is in the interest of business and the interest of the community to let people who are conducting business which is eompetitive understand that there is no profit too great to be approved, if it is the result of the exercise of brains and character, under conditions of industrial liberty. I think we want to let people understand that it is not 15 or 20 or 30 or 100 per ceut that we condemn. We ought to congratulate people in making that much, and we ought to congratulate ourselves that they are making it, if it is made under conditions of natural competition. And it is only when conditions are constrained that we have any interest in how large returns are made."

\$80. (6) The difficulty in determining what size is illegal is a strong argument against making size, in and of itself, a judicial test of illegality. Whether the unit attacked occupies a preponderant position in the business may possibly be ascertained like other ultimate facts to which legal consequences attach. But in many cases it certainly cannot be known in advance. It will depend upon the conditions of each business and upon surrounding circum-

that "posaibly, effieiency is 60 abundant that in experience there never will be as there never has been such a monopolizing."
63-Report of hearing before the Senate Committee on Interstate Commerce, 1245. 
stances of an intricate and changing character. It may be that in one industry a single unit doing 25 per 'cent of the business might occupy a preponderant position, while in another, one with 40 per cent might not. When asked by the Senate committee what limit he would place on the size of corporations, what standard he would fix, and how he would phrase it, Mr. Brandeis said : ${ }^{64}$

"I do not think that I am able at this time to state the exact provision which I should make. I feel very clear on the proposition, but I do not feel equally clear as to what machinery should be invoked or the specific provision by which that proposition could be enforced."

Then he goes on to say: ${ }^{65}$

"I am very clear that the maximum limit could not be properly fixed in dollars, because what would be just enough for one business would be far too much for many others."

Apparently he favored some standard which took account of the percentage of the market controlled. But even here he was vague as to what percentage would be illegal. He was clear that 10 per cent would be legal, but that 40 per cent might not. ${ }^{66}$ Mr. Brandeis' difficulties in dealing with the standard of size for business and industrial units where the power of the legislature was involved, are surely not diminished where the power of the court is invoked. The difficulty is not solved by being embalmed in any such phrase as "preponderant position in the business." It is clear that whether a business occupies such a position is a good deal like determining whether anyone has been guilty of negligence. No one can tell what the legal consequences of acts may be until the trial is had, and the courts are through. Can the control of property engaged in industrial and commercial pursuits and operating in a delicately adjusted field from day to day stand being faced at all times with such a test of legality? If such a test were adopted, the motive to err on the safe side in order to avoid indictment might so impede the shift from

64-Ibid., 1174.

66-Ibid., 1175.

65-Report of hearing before the

Senate Committee on Interstate

Commerce, supra, 1175. 
smaller to larger units as to result in positive public evil. Where the violation of a highly penal statute like the Sherman Act is involved, is it fair to subject business men to indictment for crime upon an issue which involved merely the size of the business which they went into together?

\$ 81. The courts have had at least one unfortunate experience in making property rights depend upon a question of size. When a non-exclusive power was created in $A$ to appoint among a class with a gift in default of appointment to the class, A must appoint something to each one. If $\mathrm{A}$ appointed too small an amount to one, it was treated in a court of equity as no appointment at all. It was called an illusory appointment. This was a very pretty doctrine sentimentally, but it made litigation every time any appointee got a considerable amount less than the others, and no test of what was a substantial appointment could ever be worked out. It always depended on the size and character of the estate and surrounding circumstances. The doctrine was spoken of with eontempt by judges and writers who had had any experience with it, and was finally abolished by act of Parliament. ${ }^{67}$ In this country courts have refused to recognize it. ${ }^{68}$ There are the same fundainental objections (many times magnified) against putting the validity of great business organizations upon any test of size alone.

§ 82. It will be said, however, that if the line as to size can be drawn for the purpose of determining what is prima facie evidence of the intent to exclude others, it can be drawn as a test

67- "Powers in Trust," John Chipman Gray, 25 Harv. L. Rev. 1, 26: "But the rule as to illusory appointments is unique in the law. Other rules of doubtful character have found defenders or apologists, but no one has had a good word for this. It has been condemned in the most unmeasured terms by judge after judge; by Sir Richard Pepper Arden (afterwards Lord Alvanley), M. R., in Spencer v. Spencer, 5 Ves. 362 (1800); Kemp v. Kemp, ibid., 849 (1801); by Sir William Grant, M. R., in Butcher v. Butcher, 9
Ves. 382 (1804); and by Lord Eldon, C., in Bax v. Whitbread, 16 Ves. 15 (1809), and Butcher v. Butcher, 1 Ves. \& B. 79, 94, 96 (1812).

"This state of things was so intolerably inconvenient and mischievous that a statute was passed abolishing the rule as to illusory appointments." [St. 11 Geo. IV. \&

1 Wm. IV. c. 46 (1830).] 68-Graeff v. DeTurk, 44 Pa. 527 (1863); Hawthorn v. Ulrich, 207 IIl. 430,69 N. E. 885 (1904). 
for illegality itself. It is not at all denied that such a line can be drawn. The argument is that when drawn as a test of illegality, it is one which the courts should not draw, but as an evidence of an ultimate fact of excluding purpose, it may be considered alone or with other evidence for what it is worth, subject like other evidence to have the inferences arising from it rebutted.

§ 83. (7) It is a fair inference from Mr. Brandeis' testimony that he did not draw any line between combinations of labor units and combinations of managing units, so far as illegal attempts at monopoly were concerned. He was asked : ${ }^{69}$

"Do you regard the closed shop in labor as a tendency toward monopoly, just as you do a combination of plants?",

to which he answered:

"Yes."

It seems hardly conceivable that $\mathrm{Mr}$. Brandeis would have made mere size and preponderant position in a labor market of a given labor union, in and of itself, a test of illegality. Indeed, it seems generally accepted that labor unions can be as large as possible and occupy as preponderant a position in the labor market as size can give, and that they only become illegal when they have the excluding purposes or indulge in unlawful excluding practices. $^{70}$ Why, then, it may be asked, make the size of combinations of managers and their properties, or of the properties alone, in and of itself, illegal?

§84. (8) It will be argued, however, that if size is not in and of itself illegal, then if 100 per cent of all the property and managers engaged in a given industry unite and have no excluding purposes or indulge in no unlawful excluding practices, the combination would be valid, although, until others could come into the field, it would have an absolute monopoly.

§ 85. In meeting the argument based upon this extreme case, we must first asssume that there is no such control of natural

69-Report of hearing before the 70-See cases, ante \& 72, n. 51, 53. Senate Committee on Interstate Commerce, supra, 1180. 
resources or strategic points as practically to exclude others, or to make their entrance into the business unusually difficult. The case put must be looked at as one in which the field is really free to others to enter. With this condition properly emphasized the combination of 100 per cent of all those engaged in a given business presents no special feature except the fact that for some time, not at all clearly defined, but upon our assumption of a free field, comparatively short, the combination could, if it chose, fix such prices as it pleased. This is offset by Mr. Brandeis' view that size alone without any excluding purposes, practices, or surrounding conditions, is quickly self-destructive by reason of the inefficiency of the combination and the resulting successful competition. It is also offset, in part at least, by the natural motive to sell cheaply enough to cause the public to buy, and at the same time not unduly encourage others to come into the business. Such prices would be fair prices because they would be the highest possible, taking into account the proper reaction from the fact that the market was free to others.

§ 86. Suppose, however, the 100 per cent. combination did continue for an appreciable term and attempted, in disregard of these natural motives, to enter upon a debauch of exorbitant and monopoly prices, regardless of consequences, during such period as was possible. That would clearly be contrary to the public interest. Nevertheless, the more outrageous the conduct of the temporary monopoly the quicker would be the relief by the entry of others and the greater the load of unpopularity which the combination would have acquired. The question is: Should the public interest be left thus to suffer temporarily in this largely problematical case, rather than that every combination of capital which approached the vague standard of a preponderant pasition in the business should be subjected to the terrors of indictment and uncertainty as to the legality of its business organization, and that every combination which had a clear preponderant position in the business, because it had from 40 per cent to 80 per cent of the market should be ipso facto illegal when it had no such power over prices as in the hypothetical case put? It is submitted that the hypothetical case of the 100 per cent combination which used its position for however short a time to charge exorbitant prices, should be left to be dealt with

Kales Sum. R. of T. $\rightarrow 6$ 
by the legislature, or by the courts when that case arises. The result which the court might conceivably feel obliged to reach in such a case is no argument in favor of the court drafting a judicial test of illegality for all combinations based upon size and preponderant position in the business, and that alone.

\$ 87. In the same way many arguments in favor of mere size being made the test of illegality, founded upon some extraordinary hypothetical action of a combination with a preponderant position in the business, may be met. For instance, it is said that a trust might withdraw "temporarily from the market" so that prices would rise, or it might release "an unusual quantity of goods upon the market" so that prices would fall. ${ }^{71}$ There are limits to be observed by the courts in the placing of restrictions upon the legality of business organizations which certainly affect the freedom of action of all in order to take care of a few problematical and remotely probable situations.

§88. (9) The effort to make mere size a test of illegality always includes the argument that preponderant position in the business confers such power and opportunity for illegal excluding practices, and the danger of their being used is so great that the entire combination should be condemned on the basis of size only. Obviously, however, if the mere possession of the power to commit a wrongful act were itself a wrong, the number of unlawful status would increase to the extent of the number of possible natural and artificial persons multiplied by the number of possible offenses. Even to be guilty of an attempt to commit a crime, the mere power is not enough. The actor must take substantial steps in the direction of the criminal act. Certainly the mere possession of power to commit a wrongful act can only become a wrong when the wrongful use of the power is so likely to follow from its possession, and is so difficult to reach, in and of itself, that the mere possession of the power must be condemned as in itself illegal. No court has yet said, and it is believed no court should, in view of our recent experiences, undertake to say, that it is necessary to hold the mere possession of the power to exclude others by illegal practices itself illegal, in order to prevent the

71-Brief of the Government in United States (now pending in the International Harvester Co. v. United States Supreme Court), 86. 
unlawful use of that power. It is enough to point to the combinations occupying a preponderant position in different industries which the government has recently investigated to make clear that since business has discovered that excluding purposes and practices are illegal, there has been an obvious tendency to abandon them entirely. This appears particularly in the case of Inited States v. Keystone Watch Case Co., ${ }^{72}$ United States v. United States Steel Corporation, ${ }^{73}$ and United States v. American Can Co. ${ }^{74}$ The International Harvester Co. appears never to have indulged in any unlawful excluding practices, or to have had any excluding purposes. ${ }^{75}$

889. (10) In Mr. Brandeis' testimony only one suggestion has been found in support of his opinion that a combination occupying a preponderant position in the business may, by reason of its size alone, be "a menace to the community." It is as follows: ${ }^{78}$

"I have considered and do consider that the proposition that mere bigness cannot be an offense against society is false, because $I$ believe that our society, which rests upon democracy, cannot enduro under such conditions. Something approaching equality is essential."

This is an echo of views which have been expressed by courts from time to time. ${ }^{77}$ The trusts, it is said, take opportunity from independent business men. They make an industrial world of employees instead of independent business men. They menace equality of opportunity and consequently that idcal of democracy which rests upon such equality.

A good deal involved in this view does not square with $\mathrm{Mr}$. Brandeis' main thesis that the trust which has only size is so inefficient that it must fail or decline in the face of the successful competition of smaller and more efficient units. If the bigness which, ex hypothesi, menaces democracy is also a menace to itself, how can it menace democracy, or the privilege of doing business in the smaller units? The fact is that when the mind is con-

72-218 Fed. 502 (1915).

73-223 Fed. 55 (1915).

74-230 Fed. 859; 234 Fed. 1019 (1916).

75-214 F'ed. 987 (1914).
76-Report of hearing before the Benate Committee on Interstate Commerce, supra, 1167.

77-Some of these cases have been collected, ante 68, n. 44. 
vinced that excluding purposes and practices can be separated from size and suppressed apart from holding mere size illegal, the substantial objections to size, as such, disappear. All that is left is a residue of fear and bias-fear that large combinations may at any time resort to a use of their power to exclude others from the business; bias against size which took root during the period when size and excluding purposes and practices were inseparable. All reasonable concessions are made to this "fear" and this "bias" when the preponderant position of any combination is made prima facie evidence of its excluding purposes and practices and hence of its illegality. It is not at all clear from Mr. Brandeis' testimony in 1911 that he would have rejected such a position if it had been presented to his mind.

In some cases, no doubt, a bias against size may be founded upon an individual preference for the simplicity of the social and industrial order of the frontier. That may be put down as incurable. Old men hark back to the days of their youth, but courts cannot contribute to the running of the social order of the present and the future by confining themselves to the use of such important improvements as the horse cars and gas mains of the '70s. The simplicity of the frontier is now largely prehistoric. The combinations which are, and indeed must be, permitted mean substantially an industrial world of employees rather than of independent individuals engaged in business. Under any restriction as to size, which the courts could posssibly pronounce, the ideal of a frontier order of society with its equal opportunity for all would not conceivably be reached. It is unthinkable that any court should settle the size of industrial units by a judicial fiat which was founded only in a sentimental bias in favor of the simplicity of life as it existed in the frontier days of half a century ago.

\$90. (11) Finally, it is important to observe that in the making of a prohibition upon the size of combinations and business units, the courts are in a very different position from the legislature, and that one who addresses a legislative committee on the subject very properly enters upon an expression of views and proposals which the court in considering the same subject could not entertain. The legislature may mark out lines as to size as it pleases with such qualifications and exceptions as it 
deems expedient. In so doing it may go upon views of economic fact which are speculative. It may even promulgate a rule founded upon the passion and prejudices of a majority.

The courts, on the other hand, in fixing the size of industrial and commercial units, must, from the nature of their function, promulgate a prohibition which is couched in general terms, universally applicable, and without illogical or detailed exceptions. It must run the chance of being too liberal and letting in some results concededly against the public interest, which the legislature must deal with in detail, rather than draw the line too tight and unduly embarrass the freedom of managers in the industrial and commerical world in their determination of the most efficient and economically proper unit of size. It must beware of basing a restriction upon economic conclusions which are uncertain and speculative, and which may be founded upon passion and prejudice rather than knowledge of essential facts and sound analysis of the situation.78

891. The making of the rule against perpetuities is a fair example of the observance by a court of these limitations. From the time the rule began to take shape as a result of Lord Nottingham's decision in the Duke of Norfolk's Case, ${ }^{7 \theta}$ the English courts have constantly adopted liberal boundary lines so as to permit testators to do what they had been accustomed to do up to the point where the courts were certain that the owner of property was going too far in the creation of remote limitations. In the Duke of Norfolk's Case, which was the beginning of this process, there was a fundamental struggle to make a far stricter rule-to draw an artificial line between future interests in terms after a

78-Ontario Salt Co. v. Merchants Salt Co., 18 Grant (U. C.) 540, 549 (1871) [616], Strong, V. C., in upholding a combination of salt producers, said: "Did I even think otherwise than I do, that this arrangement was injurious to the public interests, I should hesitato much before $I$ acted on such an opinion, for I should feel that I was called on to relieve parties from a solemn contract, not by the mere application of some well-established rule of law, but upon my own notions of what the public good required-in effect to arbitrarily make the law for the occasion. I can conceive no more objectionable instance of what is called judge-made law, than a decision by a single judge in a new and doubtful case that a contract is not to bind on the ground of public policy."

79-3 Ch. Cas. 1 (1682). 
life estate and future interests in terms taking effect at the death of the first taker, but after an absolute interest. Indeed, it was only by the narrowest margin that this step was avoided and Lord Nottingham's view adopted. ${ }^{80}$ The generalization thus worked out permitted Peter Thellusson to direct an accumulation of his estate for a period measured by a considerable number of lives in being at his death. ${ }^{81} \mathrm{He}$ could, as a matter of fact, have provided for an accumulation for the period of these lives and twenty-one years thereafter. The result thus reached under the rule against perpetuities was regarded as contrary to the public interest, and the Thellusson Act was passed to control accumulations for the future. In this country some legislatures have thought the common law rule against perpetuities too liberal and have made the limit two lives in being, without any term of twenty-one years.

Apply to our problem the vision and judgment which Lord Nottingham brought to the creation of a test regarding the validity of future interests, and our conclusions are not in doubt: When the courts took the stand that a combination occupying a preponderant position and having excluding purposes or using unlawful excluding practices was illegal they took sure ground and have had no reason to regret it. They will equally be on safe ground if they hold that size and preponderant position are prima facie evidence of the purpose to exclude others which places upon the combination the burden of rebutting the inference of excluding purposes and practices. But when the courts undertake to say that mere size alone is against the public interest they enter the realm of uncertainty and speculation both as to economic facts and results. It is the realm where law-making "may degen-

80-In the Duke of Norfolk's Case, 3 Ch. Cas. 1, Lord Chancellor Nottingham was assisted by Lord Chief Justice Pemberton, Lord Chief Justice North, and Lord Chief Baron Montague. The Lord Chancellor differed from these judges, and entered a decree in accordance with his own opinion, and disregarded the opinions of those whom he had asked to assist him. After Lord Nottingham's death, Lord North became Lord Keeper of the Great Seal, and upon a bill of review he reversed the decree of Lord Nottingham, but on appeal to the House of Lords the decree of the Lord Keeper was reversed and the decree of the Lord Chancellor affirmed.

81-Thellusson v. Woodford, 11 Ves. 112 (1805). 
erate into the mere private discretion of the majority of the court as to a subject of all others most open to difference of opinion and most liable to be affected by changing circumstances," 82 and where the quaint language of an English judge becomes applicable: "Public policy is an unruly horse, and when once you get astride it, you never know where it will carry you." 83

\section{Conclusion}

8 92. In the decades from 1880 to 1900 a great fear of the power of new combinations spread throughout the United States. The power which came from combination had been, and was being, abused. Unlawful excluding purposes and practices were the regular accompaniments of combinations which occupied a preponderant position in the business. All such combinations, therefore, received a bad name, and combination was, in and of itself, distrusted. Since perhaps 1910 it has become each ycar more apparent that the evil side of combination was the existence of the excluding purposes and the use of unlawful excluding practices. Each year it has become more apparent that these excluding purposes and practices may be eliminatetd and the freedom of the market secured, without touching the combination itself. It has become more and more apparent that the trausition of business units from smaller to larger and then to still larger units is a desirable side of combination, and a movement in which the public has a vital interest. It has become more and more apparent that some experiment was necessary to determine what was the most efficient size for business units in a given branch of industry, and that where the field is really free to others to enter, the determination of the question of proper size may be left to the play of economic forces. If these obscrvations are sound, they clearly point to the drawing of the line between good and bad trusts at the place where the excluding puproses or unlawful excluding practices commence. It is sufficient protec-

82-Comment on Hilton v. Eckersley, 6 E. \& B. 47 (1855) by the editors of Smith's Leading Cases, Mr. Justice Willes and Mr. Justice Keating (4 ed. vol. 1, p. 286).
83-Per Burrough, J., in Rich. ardson v. Mellish, 2 Bing. 229, 252 (1824). 
tion to the public and a sufficient concession to the possible abuse of power by combinations, and any bias against them, that every combination having a preponderant position at the time it is organized must sustain the burden of rebutting a prima facie inference of excluding purposes and unlawful excluding practices. 


\section{CHAPTER VI}

\section{COMPETITIVE METHODS}

893. If we regard torts as consisting of an act of the defendant resulting in damage to the plaintiff which is without justification, we have here to consider how far the social interest in freedom to compete will justify acts of competition which accomplish what they were designed for, namely, damage to the defendant in his business.

First of all we find certain classes of acts resulting in damage which do not derive any justification at all from the fact that they are used in competition to defeat a business rival, e.g.: inducing another trader to break his contract, fraud, libel, intimidation, and coercion.

Secondly, we come at once to a class of acts used in the course of competition and causing damage, which are sometimes justified and sometimes not. Whether or not a justification exists seems to depend upon the size of the aggressor and his position in the business relative to the entire business. That is to say, if the act and damage are committed by one who has no preponderant position in the business and against one who has a fair opportunity to achieve the same position as the aggressor and to retaliate effectively, no tort has been committed. The fact of competition between business rivals and the social interest in such competition justifies the act and damage. But if the aggressor has a preponderant position in the business, the same act and damage are not justified and he will be guilty of a tort.

This subject is new. The law is in the making. The distinction suggested is fairly discernible in the cases. Even if it be the true line of distinction, still judicial decisions have done nothing as yet to define whether a preponderant position relative to the entire business is an essential, or whether the tort will arise if the aggressor has a preponderant position relative to that of the one damaged. Nor has any attempt been made as yet 
to say what position is preponderant relative to a given business as a whole.

The soundness of the discriminations here suggested can best be tested by an analysis of the results reached in the following leading cases.

§94. In Mogul Steamship Co. v. MeGregor, Gow \& Co. ${ }^{1}$ a combination of steamship owners operating in the China trade did not commit a tort to a business rival, whose trade was damaged by the offer of specially favorable terms to shippers who would deal exclusively with the combination and by cutting prices in particular localities to drive away competition. This was a case where the act and damage were justified because done in the course of competition. The social interest in competition permitted these methods. There was no showing that the defendants had any preponderant position in the business which made it impossible for the plaintiff to retaliate by doing the same thing. For aught that appears, the defendants had a large fleet which could have been mobilized in the China trade and could have prosecuted the same methods which were complained of.

\$95. The same remarks apply to the case of Scottish Cooperative Wholesale Society v. Glasgow Fleshers' Trade Defense Association. ${ }^{2}$ In that case the butchers at a foreign cattle auction exchange declared that they would not buy at all unless the exchange refused to sell to the Co-operative Society, which was the butchers' rival. It was held that this was not a tort against the Co-operative Society. The butchers were the stronger in this instance, but they did not have any preponderant position relative to the entire business. The opportunity was open to the others to increase their strength and retaliate. It was a case of mere competition and nothing else.

\$96. In Allen v. Flood ${ }^{3}$ there was competition between two groups of workers. Each wanted the iron work in shipbuilding yards. One threatened to strike unless the employer discharged those belonging to the other. This was not a tort against the men discharged. The case clearly establishes the right of employees to strike as a means of successful competition with another group

1-L. R. [1892] A. C. 25 [309].

2-35 Scot. L. Rep. 645 (1898).

3-L. R. [1898] A. C. 1 [337]. 
of employees which is seeking from the same employer work which the first group desires to do. As a matter of fact, however, it goes farther for it made no difference in Allen v. Flood that the employer had not given and was not going to give any of the iron work in his yard to the men discharged. Nor did it make any difference that the discharge of the plaintiff was secured as part of the competitive struggle of the defendant to prevent the plaintiff from securing the iron work in dispute in other yards and at other times.

It should be noted that there was no preponderant position in the labor market on the part of the men who threatened to strike. They evidently were stronger at the point in question than the plaintiffs. After all, however, it was a simple case of rivalry and competition between the two groups. The plaintiffs were equally privileged to use the same methods if they could do so effectively. The court could hardly do otherwise than give effect to the freedom of competitors to compete in this manner. The novelty about Allen v. Flood was the fact that the court found itself confronted with a case where one group of laborers was competing with another group and using the strike as a means to achieve success in that competition.

\$ 97. In Quinn v. Leathem the employees of $M$ threatened to strike for the purpose of inducing $M$ not to deal with $L$ so that the group of employees to which the employees of $M$ belonged could secure the places of L's employees. This threat of strike resulting as it did in $M$ withdrawing his patronage from $L$ was a tort to $L$ for which the employees of $M$ were liable. Here the act and damage were not justified by their relation to a competitive struggle and hence constituted a tort. Furthermore, size or preponderant position on the part of the defendant organization was held not to be necessary to the existence of the tort. The act and damage would have been a tort regardless of the size of the defendant.

The distinction between this case and that of Allen v. Flood is clear. In Allen v. Flood, the employees of $M$ threatened to strike for the purpose of compelling $M$ to discharge the rival workmen of the defendants. The defendants, who were employees 
of $\mathbf{M}$ struck or threatened to strike to require $\mathrm{M}$, who had $a$ direct relation with the rival group of employees to discharge them from his employ. In Quinn v. Leathem on the other hand, tise employees of $M$ threatened to strike to induce $M$ to withdraw his trade from $\mathrm{L}$ so that $\mathrm{L}$ would discharge the rival group of employees. Why make any distinction between these two cases? In Allen v. Flood the competition was between the two groups working for the same employer and the pressure which one group brought to bear upon the other was direct because the defendant group of employees threatened to strike to induce their employer to discharge the rival group. In Quinn v. Leathem, the pressure was indirect and required the threat of harm to those who had no relation to the competitive struggle in question, or any direct power over the group of employees with which the parties threatening to strike were competing. Why should this distinction make a difference? The question is largely one of degree. The line must be drawn somewhere. Where better than here?

\$98. Curran v. Galen ${ }^{5}$ and National Protective Association v. Cumming ${ }^{6}$ should be considered together.

In Curran v. Galen the union and the employer had a contract that non-union men were to be discharged. This was carried out and the discharged non-union employees sued the union in tort and recovered. In National Protective Association v. Cumming, the union threatened the employer with a strike unless the non-union men were discharged. The discharged nonunion men were not permitted to sue the rival union in tort.

Thus stated the only distinction between the cases is that in Curran v. Galen there was an agreement between the union and the employer, while in the National Protective Association case there was merely a threat by the employees to strike. Does that make any difference? The agreement is more peaceful than the strike, and yet the agreement effects a combination of employers and employees which does not usually accompany the strike. Is it possible that you can do by strike what you cannot do by agreement?

It is submitted that the sounder line of distinction between

5-152 N. Y. 33 (1897) [408].

6-170 N. Y. 315 (1902) [413]. 
the two cases is this: In Curran v. Galen the union was a national organization. It had size. We may assume that it had a preponderant position in the particular group of labor which it represented. It had the power which size gave it. Against that power the individual unorganized unit had no chance for retaliation. The exclusive contract was itself direct evidence of an intention to exclude others from the labor market and thus secure a monopoly. When such an excluding practice as this contract is employed by such a combination with such a purpose, the resulting damage can not be justified upon any ground of permitting free and unrestricted competition. On the other hand in National Protective Association v. Cumming, we have a contest between two unions. One was seeking to secure certain work against the other. One union was more powerful than the other, but it could not be said that it occupied a preponderant position in the labor market of the country. The court in the National Protective Association ease was after all, dealing merely with the competition of two collective units. The use by one of the strike in order successfully to compete with the other was merely competition, such as occurred in the Mogul case ${ }^{7}$ and Allen v. Flood. ${ }^{8}$

§99. Berry v. Donovan ${ }^{9}$ follows Curran v. Galen. The discharge of the non-union employee pursuant to a contract between the union and the employer was held to be a tort to the discharged employee for which the union was liable. The union here was not so much competing with the plaintiff for his job as it was attempting to force the plaintiff into the union so as to strengthen the union. The union was clearly a national one and it may be assumed that it had a preponderant position in the labor market for shoe workers. The purpose to exclude others from that labor market was elearly present. Hence the monopoly feature offsets any public interest in allowing free competition. Clearly if the defendant union had threatened to strike, instead of securing a contract, it would equally have been guilty of a tort. This would not in the least have been contrary to Allen $\nabla$. Flood, because there the court was dealing

7 -Ante 894.

9-188 Mass. 353 (1905) [453].

8-Ante 896 . 
with two local unions, each competing with the other for the work in question. In Allen v. Flood no case was presented of the defendant union occupying a preponderant position in the labor market as against its rival.

\$100. In Vegelahn v. Guntner ${ }^{10}$ the striking employees of a storekeeper were seeking employment in the store at a price which they named. To accomplish their purpose of obtaining employment, they picketed in front of the store and peacefully attempted to persuade those who came to take their placestheir rivals-not to do so. This was held to be a tort and was enjoined.

This decision may be sustained on the ground that however peaceful the strikers may have been they were in fact interfering with the storekeeper's trade and customers. This trade is dependent upon a relation so delicate that the actual presence of picketers in front of the store will drive it away, however peaceful they may be. The strikers, therefore, are in the position of bringing to bear upon the storekeeper a secondary pressure, as in Quinn v. Leathem. They are keeping away the storekeeper's customers, so as to bring the storekeeper to terms. They are in effect turning away the storekeeper's customers, so as to bring pressure upon the storekeeper not to employ the rivals of the strikers.

Suppose this basis for the decision be withdrawn. Suppose the employer is a mail-order house, so that there are no customers whose physical presence is interfered with. Even in such a case we have an effort by the strikers to achieve a localized monopoly by combination. Every person who is turned away from the employer is a party to a combination to achieve a localized monopoly for the striking employees, of places in the particular store. If all who would seek places in that store can be turned away the monopoly is, for the time being at least, perfect.

The case is not in the least different from the blacklist by employers. If all the employers from whom a man might secure work which he is particularly fitted to do, combined in the most peaceful way to keep him from obtaining work so that he would

10-167 Mass. 92 (1896) [440]. 
come to the employers' terms, we shonld have a localized monopoly by employers directed against that man. Such action would be $a$ tort to the employee who was blacklisted.

The same principle is involved where bidders at a public auction combine, however openly and peacefully, to keep others away from the bidding.

8101. In Bohn Mfg. Co. v. Hollis ${ }^{11}$ no tort was committed by a retailers' association which notified its members not to deal with the wholesalers who sold direct to the consumer. Such a boycott was a legitimate means of protecting the business of the retailers. The manufacturers and retailers were possible competitors and yet each had a field of business which supplemented the other and was not competitive. Any publie interest which there may be in having the wholesalers sell directly to the consumers is offset by the public interest in not putting established retailers out of business. Furthermore, the courts do not undertake to decide between competing economic prineiples but simply insist on equal freedom for the devotees of each to compete and survive, if possible. The retailers' association eould, therefore, organize to protect the retailers from the manufacturers. Having organized they could use the weapon of the strike or the boycott, or refusal to buy from the wholesalers who eompeted with them. In Allen v. Flood one group of laborers used the strike to prevent the employers from dealing with a rival labor group. Here the retailer uses the strike to prevent the wholesalers from entering into competition with the retailers. Both are legitimate methods of eompetition, so long as they are not used by a union or association having a preponderant position in the market.12

\$102. In Martell $\nabla$. White 13 we have an association of quarriers, manufacturers and polishers of granite at a single important granite center. These three groups supplemented each other. The quarriers furnished stone to the manufaeturer who passed it on the polisher. Together they formed an association which was complete within itself. Assume that competition between the members in each group was suppressed and that

11-54 Minn. 223 (1893) [473].

13-185 Mass. 255 (1904) [478].

12-See post $\$ 132$. 
the work was divided between them on some agreed basis. The court assumed that this organization of the three groups was lawful and proper. To maintain such an organization, however, the members of each group must be loyal to its rules and regulations. If quarriers at will could sell to outsiders, and if manufacturers could do the same, the organization must quickly have fallen to pieces. The real question presented was whether the association could enforce loyalty from its members by fining them for sending work to outsiders. It was held that it could not. The fine, it was held, was an unlawful means, or based upon an unlawful contract between the parties. Why? If the association was lawful and loyalty to it was necessary, why could not the members by mutual agreement provide such a means as a fine to make it effective?

In discussing the case of Bohn v. Hollis, the court says no fine was there imposed. On the contrary "inducements naturally incident to competition" were used. But in the Bohn case the association was seeking to prevent the wholesalers from competing with the members of the retailers' association in selling direct to consumers. The natural method was to strike against the wholesaler who did compete. There was no rational basis for any fine upon any member of the association unless it were required in order to enforce the strike. But when the exigencies of the situation require all the members of an association to deal only with each other the strike against outsiders is entirely inappropriate and the fine of members becomes a naturally effective and appropriate step. The different situations clearly call for different expedients. Conceding, therefore, the legality and propriety of the association in Martell v. White it should follow that the fine of members was quite as proper and appropriate as the strike in the Bohn case and should have been held legal.

What has thus far been said presupposes that the association in question did not have any preponderant position in the business in which it was engaged. Now suppose it had. The situation is quite changed. The power of the preponderant organization in making such exclusive arrangements would be to force all into the association or to exclude them from doing business entirely. The preponderant position coupled with the exclusive 
arrangement would show a monopoly purpose. Hence, the fine would become an instrument to secure a loyalty to the organization which would become the effective means of achieving the monopoly purpose. Hence it would quite properly be held illegal.

Martell v. White is to be sustained, if at all, on the ground that such an attempt at monopoly existed. That depends upon whether this association did or did not oceupy a preponderant position. It clearly did at the Quincy quarries. Were these so isolated and was the cost of transporting granite such that Quincy must be regarded as a market by itself, cut off from the rest of the world so far as quarrying, manufacturing and polishing granite are concerned. Perhaps so-perhaps not. We do not know the facts. This vital aspect of the case was not developed. Yet the court may have been profoundly influenced by it. It may have looked upon this association as being preponderant in Quincy and that Quincy was a market by itself.

\$103. In Macauley v. Tierney 14 we have two groups of plumbers competing. One was organized, the other was not. The organization in the course of competition refused to deal with any manufacturer who dealt with a non-member. This was held to be lawful. It was not a tort to the non-member on the part of the plumber's' association.

Laying aside all question of the size and preponderant position of the plumbers' association, we have here Allen v. Flood ${ }^{15}$ over again-that is to say Allen v. Flood in its simplest form. It is the strike by one plumbers' association against manufacturers if they deal with the other and rival group. If the plumbers' association had had an agreement with the manufacturer that they would not deal with outsiders it would have been valid under the Mogul case. ${ }^{16}$

If, however, we introduce the fact that the plumbers' association had a preponderant position in the plumbing business throughout the United States the whole situation is ehanged. The plumbers' association would then have a power over the manufacturer, and it would be using that power to exelude others

14-19 R. I. 255 (1895) [487].
15-Ante \& 96. 16-Ante $\$ 94$.

Kales Sum. R. of T. -7 
from the plumbing business. That is a clear attempt to secure a monopoly. It is the same as if the Standard Oil Company refused to sell to anyone who dealt with an independent. It is the same as if the International Harvester Company refused to sell to any farmers who dealt with an independent. Such acts would be unfair methods of competition and illegal and constitute a tort on the part of the combination against the independent manufacturers' damaged.

Did the plumbers' association in Macauley v. Tierney have a preponderant position? It was a national organization. One may suspect that it did have a preponderant position. The court, however, entirely neglected this aspect of the case. It failed to consider the effect which the preponderant position of the plumbers' association would have had if it had existed. Perhaps it is fair to say that in $\mathbf{1 8 9 5}$ it was not apparent to the court that preponderant position was to have the consequences which it is now perceived it must have.

\$ 104. In Brown \& Allen v. Jacobs' Pharmacy Co. ${ }^{17}$ the members of the retailers' association refused to deal with wholesalers who sold to other retailers, who cut prices fixed by the retailers' association. This was held to be a tort and the act of the retailers' association was enjoined at the suit of the outsider.

Here we have the strike against the wholesaler used to require the wholesaler to bring pressure upon the outsider to observe the association's rules as to prices. We have also the retailers' association clearly occuping a preponderant position in the business. It was a national organization. The court vaguely hints at this feature of the case. The fact that the association of retailers deals directly with the maintenance of prices is an assumption of proponderant position and power to exclude others, ${ }^{18}$ so that the association of retailers presents all the features of an illegal attempt at monopoly. The act complained of in aid of that monopoly is clearly a tort.

$\S 105$. In National Fireproofing Company v. Mason Builders' Association ${ }^{19}$ we have a case where the competition was between

17-115 Ga. 429 (1902) [496]. 19-169 Fed. 259 (1909)

[522]. $18-$ Ante 870 . 
the group of bricklayers who wanted inside as well as outside work and the group of bricklayers who did only inside work, euch as tiling and fireproofing, the contracts for which were sublet to special contractors. It may be assumed that the only labor employed was union labor, and that all the bricklayers belonged to the same union. The point was, however, that the special contractors for the inside work hired bricklayers who became inside specialists. To prevent such a development the bricklayers refused to work unless the entire contract for all bricklaying was given to the general contractor, who could then give inside work to outside men. The operation of this was to prevent the fireproofing company from doing business as they wanted to, with specialist bricklayers to lay their particular kind of fireproofing. The action of the bricklayers, causing damage to the fireproofing company, was held not to be a tort and an injunction against the bricklayers was refused.

Considered apart from any question of size or preponderant position on the part of the bricklayers' association, the decision is correct. It is distinctly the case of Allen v. Flood ${ }^{20}$ over again. For the moment the two branches of the same union come into competition. The many want to work in one way and the minority were willing to specialize. The majority threatened to strike unless the builder let his contract in such a way as to stop the specialization. That was legitimate competition between the groups of workmen just as it was in Allen v. Flood. The fact that the fireproofing concern was aiso interfered with because of its relation to the contract made no difference. No doubt third parties are frequently affected when one group in competition wins out against another.

If, however, the bricklayers had a preponderant position which they were using to exclude others from a certain kind of work then the threats of strike must have been a tort to the specialist group of bricklayers. But suppose they waived the point or released it, or refused to enforce their right. Suppose their sympathies were with the majority and they were willing that the views of the majority should prevail. Could the fireproofing concern sue? That depends upon whether there was any inde- 
pendent tort committed to it. The fireproofing concern was only damaged as an incident to the competition between the majority of the bricklayers and the specialist bricklayers. If the specialists did not object, how can it be said that any tort was committed to the fireproofing concern? If a competitor submits to a rival, others who are damaged by reason of his submission, have not suffered a tort. The court clearly took this view. It refused to let the fireproofing concern take any advantage of the fact that by reason of size and preponderant position of the bricklayers' association, a tort had been committed to a group of specialist workmen. This appears rather vaguely in the court's assertion that the mere fact that the bricklayers were an illegal organization does not give the plaintiff a right to sue at common law or under the Sherman Act. Having taken this step, the court, apparently, eliminated any fact of preponderant position of the bricklayers from the case for all purposes. After that it was easy to find that no tort had been committed to the specialist bricklayers or to the complainant-the fireproofing concern.

§ 106. Park \& Sons Co. v. National Druggists Association 21 and Klingel's Pharmacy v. Sharp \& Dohme ${ }^{22}$ should be considered together.

Both cases alike arise on demurrer and in both alike the manufacturer or an association of manufacturers or wholesalers of drugs refused to sell to retailers who did not keep up the prices of articles on resale. In both the plaintiff to whom this refusal had been made was suing the manufacturer in tort or to enjoin his action. In the Park \& Sons Case the demurrer was sustained. No tort had been committed. In the Klingel Case the demurrer was overruled. A tort had been committed.

In Klingel's Pharmacy Case, the defendants were two wholesale drug houses which acted in connection with a third defendant which was a retail druggists' association. These three had formed a combination by agreement by which the wholesale houses would not sell to any retail druggist who cut prices contrary to the rules of the Retail Druggists' Association. This was using the boycott or the blacklist to force the plaintiff into 
a combination of retail druggists which eliminated competition as to prices generally in the retail business. If the position of this combination in the market had been a preponderant one, or was assumed to be so from the effectiveness of its acts against the plaintiff, the boycott would be a tort and might properly be called an unfair method of competition.

In the Park \& Sons Case, we have, however, an entirely different situation. The defendant in that case was the National Wholesale Druggists' Association. It had induced the manufacturers of patent or proprietary medicines to refuse to sell to the complainant because the latter refused to comply with the plan of the association that the prices of such articles as fixed by the manufacturers should be kept up to. a certain standard on resale. This was not a combination among the retailers or wholesalers to kcep up prices generally. It was merely a plan to secure each manufacturer the means whereby he could prevent the cutting of the price fixed by him upon the resale of his manufactured article by the retailer. It is just as if all the manufacturers of patent medicines had agreed not to furnish such articles to anyone who did not keep up the price on resale as requested. Such an arrangement would not constitute a combination of the manufacturers to fix prices generally. Each manufacturer would still compete with the others in the production of medicines and in prices to be charged. The agreement of the manufacturers would merely operate to protect a certain method of marketing through the retailer. That method, as already indicated, ${ }^{23}$ consists in the manufacturer doing a part of the selling-namely, advertising, standardizing and packing the goods. The retailer is a mere distributor who collects the price. To permit the retailers to compete with each other in the sale price of each manufacturer's product destroys or disrupts this method of marketing. When the interests are all balanced it is fourd that the immediate advantage to a few from permitting the retailers to compete as to the price of the manufactured article is offset by putting the ban of illegality upon a method of marketing which manufacturers have found effective in building up a business which at all times remains entirely competitive 
with the businesses of other manufacturers operating in the same way. Hence the action of the manufacturers would not be a tort.

The Klingel and Park and Sons cases each present a situation where an attempt is made to force the retailers into a combination to keep up prices, but the difference is this: the retailers in the Klingel case are forced in for the purpose of eliminating competition as to prices generally in the retail business. In the Park \& Sons case they are forced in to keep up the prices on single articles only as they are fixed by individual manufacturers whose products are in competition with each other. The prices, therefore, in the Park \& Sons case, which the retailer keeps up are in fact competitive prices established by the competition of manufacturers each of whom do business in the same way through the retailers.

\$107. In State v. Huegin 24 three Milwaukee newspapers agreed to refuse advertising space to any person who paid the higher price for advertising space demanded by a fourth and rival newspaper. This agreement was held to be a crime. $A$ fortiori it was a tort to the fourth newspaper.

How is this to be reconciled with the freedom which business rivals have to compete with each other and in so doing to strike? The advertisers were the common employers of the rival newspapers. One group of three newspapers threatened to strikethat is, they threatened that they would not take advertising matter from those advertisers who dealt with the fourth and rival newspaper. What is the difference between this situation and that of a group of employees striking against an employer in order to compel him to discharge a rival group of employees? 25 It is submitted that there is no difference unless we regard the three newspapers as occupying a preponderant position in a particular advertiser's market. If so, then we have the strike by a combination occupying a preponderant position for the purpose of putting out of business the only rival and thereby obtaining a monopoly. The monopoly purpose and the preponderant

24-110 Wis. 189 (1901) [536].

25-As in Allen v. Flood, L. R. [1898] A. C. 1 [337] ante $\$ 96$. 
position which gives the power necessary to carry out an excluding competitive practice are both present.

8107a. Tuttle v. Buck ${ }^{26}$ and Dunshee v. Standard Oil Company ${ }^{27}$ should be considered together.

In Tuttle $\nabla$. Buck a complaint was held sufficient which stated in substance that the defendant, a banker and man of wealth and influence in the community, and nowise interested in the occupation of a barber, established a barber shop and employed a barber to carry on the business, not for the sake of entering the business or of profit to himself, but regardless of loss to himself and for the sole purpose of driving the plaintiff out of his established business as a barber. Here we have a simple case of an act on the part of the defendant causing damage to the plaintiff. The only justification-that of freedom to compete with a rival and triumph over him by the usual means of persuasion, advertising, service, and cutting prices-was eliminated because this was not, in fact, competition, it was damage by means of what was competition in form only.

In Dunshee v. Standard Oil Company the plaintiff, a retail dealer, had been accustomed to buy from the Standard, as wholesaler. It gave up this practice and bought from independent wholesalers. The Standard then went into the retail business for the sole purpose of competing with the plaintiff and destroying his business, which it did. The methods used were to seek out the plaintiff's customers and supply their wants before the plaintiff reached them. It does not appear that they cut prices so much as that they gave a prompter service to the plaintiff's customers than the plaintiff could give. When the plaintiff had been driven from the retail business the Standard withdrew from retailing. The Standard Oil Company was held liable in tort on the authority of Tuttle v. Buck.

There is, however, a wide difference between the two cases. In Tuttle $\nabla$. Buck there was, in fact, no real competitive situation at all. What was in form a competitive method was used as one might use a stone to throw at the plaintiff's shop window. In the Standard Oil Case the defendant was in the oil business,

26-107 Minn. 145, 119 N. W. 27-152 Ia. 618, 132 N. W. 371 946 (1909). (1911). 
and in competition as a wholesaler with other wholesalers. This competition consisted in attempting to secure retailers as customers. Certainly the Standard (apart from any question of its size and preponderant position) could have refused to deal with a retailer who dealt with independent wholesalers. But that step would have been suicidal if the independents were strong in the locality. Under the circumstances the natural and necessary plan would be for the Standard to establish its own retail business. That would mean competition with other retailers; but if, by competing with such retailers or with any one of them it could induce the retailers again to deal with the Standard rather than the Independents, there would be no further need for the Standard to carry on a retail business. It could legitimately retire from the retail branch of the business and become a wholesaler solely.

So long as we leave out of consideration all question of size and preponderant position of the Standard Oil Company in the oil business, it is difficult to perceive why its acts were not justified by the social interest in the freedom to compete. The moment, however, it is assumed that the Standard Oil Company had a preponderant position in the business, the whole situation is changed. The use of its power to put the independents out of business, by using a localized competitive effort against the independent wholesalers' customer, becomes an unfair and illegal method of competition, and a tort to the retailer damaged. The justification arising from the social interest in the freedom to compete fails.

The true distinction between the two cases is this: In Tuttle v. Buck there was no competitive struggle at all. In the Standard Oil Case there was, but the defendant competitor occupied a preponderant position in the business which limited its freedom to compete and caused acts of competition to be torts which would not have been if employed by well matched units of inconspicuous size. 


\section{PART 2 \\ THE SHERMAN ACT}

\section{CHAPTER VII}

\section{PROBLEM OF CONSTRUCTION}

\$108. The Sherman Act has given the Federal government an opportunity to deal through its judicial department with contracts, combinations, and conspiracies in restraint of trade, monopolies, and attempts to monopolize. ${ }^{1}$ The first sentence of the act declares certain contracts, combinations and conspiracies to be illegal generally. It reads:

"Every contract, combination in the form of a trust or otherwise, or conspiracy, in restraint of trade or commerco among the several states, or with foreign nations, is hereby declared to be illegal."

Section 2, which speaks of monopoly or attempts to monopolize, merely declares that

cevery person who shall monopolize, or attempt to monopolize, or combine or conspire with any other person or persons, to monopolize any part of the trade or commerce among the several states, or with foreign nations, shall bo deemed guilty of a misdemeanor."

1-Standard Oil Co. v. United, prohibited at common law. I ask States, 221 U. S. 1 (1910) [1089] the Senator from Massachusetts ("The debates show that doubt as whether a monopoly coming within to whether there was a common law the definition which he gives is proof the United States which governed the subjects in the absence of the legislation was among the influences leading to the passage of the act."')

21 Cong. Rec. 3151-3152: "Mr. Kenna. If the Senator will permit me, I should like to ask him whether a monopoly such as he defines is hibited at common law. Mr. Hoar. I so understand it. Mr. Kenna. Then why should this bill proceed to denounce that very monopoly? Mr. Hoar. Because there is not any common law of the United States." 
There is no explicit provision that the acts of monopolizing or attempting to monopolize are generally illegal. Nevertheless, monopolies and attempts to monopolize are properly regarded as prohibited. Whether this is because monopolies or attempts to monopolize are really included in the prohibition of the first section or because they are made illegal by the second section is immaterial. Indeed, the United States Supreme Court in the Standard Oil Case suggests that the second section may include acts which were not covered by the first. 2

$\S 109$. The most important question regarding the construction of the Sherman Act is this: Does the prohibition of the act apply to every contract, combination, and conspiracy which is (however slightly) in restraint of trade, according to the literal significance of those words; or does it apply only to every illegal contract, combination or conspiracy in restraint of trade - the determination of what contracts, combinations, and conspiracies are illegal, because in restraint of trade, being left to a standard outside of the act? In short, does the act by its terms prohibit any specified conduct, or does it simply induct the federal courts into a new federal jurisdiction there to operate and obtain results based on some standard outside the terms of the act?

8110. There are three ways of describing this outside standard: It may be called the standard of the common law. It may be described as the fiat of the court itself, based upon its collective judgment and reason. It may be referred to as an authority to obtain results, just as a common law court reached them, i.e., by the exercise of a certain technique of judicial reasoning, which includes a consideration of the conclusions which other common law courts have reached while at the same

2-Standard Oil Co. v. United States 221 U. S. 1 (1910) [1098]: "In other words, having by the first section forbidden all means of monopolizing trade, that is, unduly restraining it by means of every contract, combination, etc., the second section seeks, if possible, to make the prohibitions of the act all the more complete and perfect by embracing all attempts to reach the end prohibited by the first section, that is, restraints of trade, by any attempt to monopolize, or monopolization thereof, even although the acts by which such results are attempted to be brought about or are brought about be not embraced within the general enumeration of the first section." 
time exercising the power to examine the basis for the results which other courts have obtained and possibly reaching a different conclusion. Characterizing the standard as that of the common law really is not different from describing it in tho other two ways, because the Supreme Court of the United States must always remain the final judge of what the common law which it adopts mas be. That introduces into the standard the fiat of the court or the technique of judicial reasoning used by common law courts. Referring to the standard as the fiat of the court is not different in fact from describing it as based upon a certain technique of judicial reasoning. It is objectionable because it suggests arbitrary action by the court instead of action based upon a recognized judicial process of reasoning. The three methods of describing the standard outside the act, therefore, really come to the same thing, but the third method is the most complete and the fairest way to describe the standard referred to. We may call it for the sake of brevity "the standard of reason which had been applied at common law."

\$111. Our principal question of construction of the Sherman Act then is: does the act by its terms prohibit any specified conduct, or does it simply induct the federal courts into a new federal jurisdiction, there to operate and obtain results in accordance with "the standard of reason which had been applied at common law"'? The latter view has now been accepted, but not before the court seemed to have committed itself to the former. The decisions of the United States Supreme Court will therefore be examined ${ }^{3}$ with a view to showing that the results reached are consistent with the application of the standard of the common law and the standard of reason which had been applied at common law, and inconsistent, in some instances at least, with the view that the Sherman Act on its face specified the conduct prohibited without reference to any standard outside the act. Then the dicta of the court will be examined ${ }^{4}$ to show how the court, after first taking the view that the act specified the conduct prohibited without reference to any outside standard, abandoned that position and adopted the view that the conduct prohibited 
was to be determined in accordance with the "standard of reason which had been applied at common law."

\$112. The principal difficulty in applying the Sherman Act is, therefore, not strictly one of construing its terms, but in determining what acts in restraint of trade and in the furtherance of monopoly are illegal according to "the standard of reason which had been applied at common law." How shall the judicial discretion which the act vests in the court to declare some contracts, combinations, and conspiracies in restraint of trade to be legal and others illegal be exercised? The uncertainty which arises from the operation of such a judicial function is no greater than that which attends any new course of decision by common law courts. ${ }^{5}$

5-It is of course arguable that the results reached by the court, while arrived at slowly and piece. meal, and with considerable expense to the individuals who litigate, are better and will last longer than if Congress had attempted a priori to prohibit certain definite acts, or to break up any clearly defined status. 


\section{CHAPTER VIII}

\section{THE DECISIONS OF THE UNITED STATES SUPREME COURT UNDER THE SHERMAN ACT}

\section{SECTION 1 \\ CONTRACTS ACCOMPANYING THE SALE OF A BUSINESS}

8113. Cincinnati Packet Co. $\nabla$. Bay ${ }^{1}$ presents the question of the validity of a restrictive covenant accompanying the sale of a business. The covenant is limited in time, and not broader than the scope of the seller's business. It is just the sort that would have been valid at common law. It was held valid under the Sherman Act. 2 If the Sherman Act prohibited all contracts which restrained trade, however slightly, surely this would have been one of those that would be void.

8114. In Shawnee Compress Co. v. Anderson ${ }^{3}$ we have a plain case (so far as the record in the Supreme Court of the United States is concerned) of many leases with restrictive covenants, all secured for the purpose of creating a combination and with the intent to monopolize the business. At common law this would have been an illegal attempt at monopoly. It was held illegal under the Sherman Act.

\section{SECTION 2}

\section{EXCLUSTVE CONTRACTS OF SALE AND PURCHASE}

§115. Continental Wall Paper Co. v. Voight ' is of little value so far as the application of the Sherman Act is concerned.

1-200 U. 8. 179 (1906) [781].

2-United States v. Trans-Missouri Freight Association, 166 U. 8. 290 (1897) [878] ("A contract which is a mere accompaniment of the sale of property and thus ontered into for the purpose of enhancing the price at which the vendor sells it, which, in effect, is collateral to such sale; and where the main purpose of the whole contract is accomplished by such sale, might not be included within the letter or spirit of the statute in question." )

3-209 U. S. 423 (1908) [785].

4-212 U. B. 227 (1909). 
The case arose on demurrer to a defense which set out a combination of 98 per cent of the manufacturers of wall paper which entered into exclusive contracts with jobbers and retailers all over the United States. This made in fact a combination between the manufacturers, jobbers, and retailers with the intent to monopolize and exclude from the business everybody else. The case is so plainly one of an attempt to monopolize which would have been illegal at common law that the court spends only a few lines in stating in substance that it assumes the illegality of the combination. 5

\section{Section 3}

CONTRACTS TO KEEP UP THE PRICE ON RESALE

§116. Dr. Miles Medical Co. v. Park \& Sons Co. ${ }^{6}$ might appear to be a case where the supreme court had held contracts, or a combination, to be in violation of the Sherman Act which would not have been invalid at common law. ${ }^{7}$ It might be used, therefore, to indicate that the Sherman Act was broader than the common law. But this is not so. The Supreme Court of the United States is the sole judge of what is the common law which it recognizes as the standard to be used in applying the Sherman Act. It may have determined, as it had a right to do, what it considered to be the common law applicable, and that this common law required the result reached in the Dr. Miles case.

In the same way, if the Supreme Court of the United States should, operating under the Sherman Act, hold that a contract by the purchaser of a mule not to use any currycombs on it except those furnished by the seller was illegal; that a contract by the purchaser of a picture not to use any cleaning or preservative material upon it except that furnished by the seller was illegal ; and that similarly a contract by the purchaser or licensee of a patented article that he would use with it only unpatented accessories sold by the seller or licensor was illegal, ${ }^{8}$ we should

$5-[820,821]$.

6-220 U. S. 373 (1911) [838]. See ante $8 \$ 32$ et seq., where this case is fully dealt with.
7-Ante 832 .

8-See ante 8841 et seq. 
not have a decision that the Sherman Act is broader than the common law, but merely that the United States Supreme Court is the final judge of what the common law, which it purports to follow, may be.

\section{Section 4}

\section{COMBINATIONS}

\section{Of Transportation Units}

\$117. The basis for the decisions in the Trans-Missouri Freight Association Case ${ }^{9}$ and the Joint Traffic Association Case ${ }^{10}$ is clear. The railroads operated under special franchises. The public was excluded from the business in general. If two were let into the business, the public policy was made plain that they should compete, and as all the rest of the public was excluded, the two had a monopoly except for the competition between themselves. When, therefore, they united, they not only violated the declared public policy in favor of competition, but they achieved an actual monopoly. All combinations of public utilities which can operate only under special franchises so that the public generally is excluded from the business, are therefore illegal per se at common law. Hence, such combinations are illegal per se under the Sherman Act where interstate or foreign commerce is involved. So far, therefore, as railroads are concerned, the proposition is literally truc, that under the Sherman Act every restraint of trade by combination and every attempt to monopolize by eombination is illegal. This, however, is not because of any language of the Sherman Act, but because of the standard of the common law or the standard of the rule of reason which the Sherman Act adopts.

This ground for the decision in the Trans-Missouri Freight Association case appears rather vaguely in the opinion of the court. ${ }^{11}$ If the case had been put squarely and solely upon this ground much subsequent difficulty would have been avoided.

9-166 U. S. 290 (1897) [862]. $11-[881,882,883,884,885]$.

$10-171$ U. S. 505 (1898) [765, 904]. 
8118. The Northern Securities case ${ }^{12}$ is to be supported on the same basis as the Trans-Missouri Freight Association and Joint Traffic Association cases. The actual decision is therefore confined to the cases where public utilities which must have special franchises under which to operate are combined. In this view it would make no difference whether the combination were by a holding corporation or an individual. The suggestion of Mr. Justice Brewer ${ }^{13}$ and of Mr. Justice Holmes ${ }^{14}$ that an individual could have bought up the stock control of both roads cannot be sustained.

The opinion of the majority contains no suggestion, however, of the proper basis for the result. It serves up cases of combinations of coal companies, trading and manufacturing companies, ${ }^{15}$ as if the court were entitled to treat combinations of railway corporations operating under special franchises in exactly the same way as it was combinations of trading and manufacturing corporations. Furthermore, much language in the opinion will justify the inference that the court was not only making no distinction between combinations of public utilities using special franchises, and trading and manufacturing units, but was asserting that no combination .which eliminated competition between the units would be legal. It was this apparent position on the part of the court that raised the storm of protest against the Northern Securities Case. Even Mr. Gray ${ }^{16}$ insisted that the court had in fact held that the elimination of competition between any units engaged in interstate commerce would be illegal. ${ }^{17}$

12-193 U. S. 197 (1904) [910].

13-[p. 948].

14-[p. 960].

15-[pp. 928 to 932$]$.

16-John C. Gray, the Merger Case, 17 Harv. L. Rev. 474.

17-Mr. Gray put the following as containing all the essential elements of the Northern Securities Case with the dramatic elements left out and picturesque ones substituted:

"Three Jerseymen, who we will call Morgan, Hill and Lamont, own each a cart and one horse. Their occupation is the carrying of eggs and chickens from the neighboring farmers to a market town over the New York border. They agree to form a corporation under the name of the Interstate Poultry Traffic Association. The only capital they turn in consists of their horses and carts, except a few dollars contributed to pay for their charter. Are they criminals liable to be fined $\$ 5,000$ apiece and imprisoned for a yearq" 
All the difficulties with the Northern Securities Case and all the grounds for objection to it are immediately eliminated when it is observed that the essential feature of the case was that the railroads combined were operating under special franchises which gave the competing roads together a monopoly as against the rest of the public, and also indicated a public policy that the railroads which had the special franchises to go into the railroad business should compete. It is not to be expected that Mr. Gray would disagree with the result of the Northern Securities Case based upon this fact. Without this element the case put by Mr. Gray concerning the three Jerseymen certainly presented no violation of the Sherman Act and this conclusion is not at all inconsistent with the result reached in the Northern Securities Case. ${ }^{18}$

\$119. The Union Pacific Case ${ }^{10}$ follows the Trans-Missouri Freight Association and Joint Traffic Association cases and the Northern Securities Case. It holds that the mere union of competing railroad corporations is illegal.

The court 20 emphasizes the application of this rule to railroads, but why a difference should be made between railroads and trading and manufacturing units is not in the least hinted at. It is submitted that the fact that the railroads can be operated only under special franchises and that the public generally is thus excluded from the business furnishes the true basis for the difference.

The competition between the Union Pacific and the Southern was very much less conspicuous than the competition between the Union Pacific and the Northern Pacific. The Union Pacific ran from Omaha to Ogden and from Ogden to San Francisco over the Southern Pacific's own line. It also ran from Ogden

18-The majority regarded the formation of the Northern Secur. ities Company and its acquisition of stock as affecting interstate com.. merce so that it might be brought within the Sherman Act. Four judges dissented on this proposition. No comment is made on this phase of the case.
Whether the interstate commerce act excluded the railroads from the Sherman Act was a question fully argued and determined in the Trans. Missouri Freight Association and Joint Traffic Association cases.

19-226 U. B. 61, 470 (1912) [981].

20-[p. 987].

Kales Sum. R. of T. -8 
to Portland. From Portland to San Francisco it operated by steamer. The Southern Pacific ran from New Orleans to San Franciseo via Los Angeles. The court assumed that a line shipping from New Orleans in the Mississippi Valley competed with a line shipping from Omaha. That is to say, shipments to the Pacific from a large area east and west of the Mississippi might go as conveniently via New Orleans as via Omaha. Hence, though these terminals were 1,000 miles apart or more, they were competitive. Then the Supreme Court found the principal competition at the other end of the line to be between the Southern Pacific to San Francisco and the Union Pacific to San Francisco via the Union Pacific's own line to Portland, and then by water to San Francisco.

It has been suggested that as a matter of fact both lines were competitive to San Francisco direct by rail because the connection between the Union Pacific and the Southern Pacific to San Franciseo would be compelled by the Interstate Commerce Commission. It has been suggested also that both lines were competitive so far as foreign trade was concerned because each reached the Pacific coast from the Mississippi Valley and it was immaterial for the purposes of foreign commerce whether they reached the same port or not.

$\S 120$. The court in the Standard Oil Case 21 affirms the soundness of the result reached in the Joint Traffic Association cases. ${ }^{22}$ It refers to "the nature and character of the contract creating - . a conclusive presumption which brought them within the statute." This leaves much to be desired in the way of explaining why there should be a "conclusive presumption" making a combination of railroads illegal, while, when manufacturing and trading corporations combined or occupied a preponderant position in the market, there was only a prima facie presumption which would bring them within the prohibition of the act. It is submitted that the explanation already offered ${ }^{23}$ indicates the difference.

§ 121. In United States v. Terminal Railroad Association of St. Louis 24 it was held that a combination of all the railroad

$21-221$ U. S. 1 (1910) [1072].

23-Ante $\$ 851,117$.

22-[1102].

24-224 U. S. 383 (1912) [962]. 
terminal facilities of St. Louis under the control of less than all the companies under compulsion to use them was illegal. At the same time the court insisted that the combination of all such facilities under the control of all the companies under compulsion to use them and open to the use of all on equal terms would be legal. Such a combination it was declared could only; further competition and commerce. It could not restrain or suppress either. Hence, the court ordered a decree of dissolution unless the defendant underwent a reorganization, as outlined by the court, which would make it a combination of all the terminal facilities subject to the control of all the railroads under compulsion to use them and without discrimination against any.

\$122. In United States v. Reading Company ${ }^{25}$ the court held illegal, in accordance with the principle of the Northern Securities Case, a combination of competing railroads. The court also held the combination to be illegal under the principle established by the Standard Oil Case, ${ }^{20}$ because it was a combination of anthracite coal companies in a limited anthracite coal field, together with the railroads serving the mines, which occupied a preponderant position in the anthracite coal business and had the actual intent and purpose to exclude others from the business or suppress their competition and thereby secure a monopoly. The facts which proved this were intricate and voluminous. The principle applied is clear.

\section{Of Trading and Manufacturing Units}

\$123. The ease of Addyston Pipe \& Steel Co. v. United States ${ }^{27}$ has already been fully dealt with. ${ }^{28}$ The opinion in the United States Supreme Court makes the case one where the preponderant position in the business as a result of combination by contract caused the combination to be illegal. Whether this was because size and preponderant position by combination were per se illegal, or whether there was an unrebutted prima facie inference of illegality, does not appear.

\$124. In Swift \& Company v. United States ${ }^{20}$ the decree attacked was entered upon demurrer to the bill, and the bill made

$$
\begin{array}{ll}
\text { 25-226 U. S. } 324 \text { (1912) [1004]. } & 27-175 \text { U. S. } 211 \text { (1899) [1047]. } \\
26-\text { Post } 88127 \text { et seq.; ante } & 28-\text { Ante } 866 . \\
8849 \text { et seq. } &
\end{array}
$$


a very plain case of excluding purposes and preponderant position on the part of the defendants. The preponderant position is set out. The defendants had control of about six tenths of the entire trade. The illegal practices are set out. There was a secret arrangement on the part of the units in the combination not to bid against each other. There were also rebates and an assumption of control ${ }^{30}$ of the market by fixing prices.

$\$ 125$. In United States v. Kissel ${ }^{31}$ the only question was the sufficiency of a plea of the Statute of Limitations. It was suffcient if the acts constituting the offense were continuing. It was held that the acts were continuing. The case is of some value as making clear that in cases of illegal combinations, restraints of trade and attempts to monopolize, the combinations created not only may, but usually are, continuing wrongs. The court apparently had nothing to do with whether the particular scheme in question practiced was an unlawful or unfair method of competition or not.

§ 126. In Standard Oil Co. v. United States ${ }^{32}$ we have a case where a manufacturing and trading unit carrying on a business which was normally free to all, occupying a preponderant position in that business, had the purpose to use its power to exclude others, and did in fact do so by illegal and unfair methods of competition. This case, together with the Tobacco Case, ${ }^{33}$ stands for the proposition that where these elements are presented the unit in question is an illegal attempt to monopolize and an illegal restraint of trade.

That the business in question was normally free to all to engage in appears from the fact that it was a manufacturing and trading business-the manufacturing of refined oil and its sale and distribution. It was not a business depending upon special franchises. ${ }^{34}$

30-Ante 870 .

31-218 U. S. 601 (1910) [1068]. 32-221 U. S. 1 (1910) [1072].

33-United States v. American Tobaceo Co., 221 U. 8. 106 (1910).

34 -It has been suggested that as there were included in the Standard Oil Company many pipe lines oper- ating under special franchises, the rule applicable in the Northern Securities Case might also have been invoked. But the opinion of the court does not suggest any such basis for its decision, and hence this aspect of the case is ignored. 
As to the size of the unit: The evidence clearly showed that the Standard Oil Company of New Jersey held a preponderant position in the manufacturing and distribution of oil. There is a difficulty, however, in finding any passage in the opinion which describes the percentage of the total business which the Standard Oil did.

It may be assumed that there was ample evidence of illegal and unfair methods of competition, particularly in the early stages of the Standard Oil Company. Curiously enough, however, the opinion of the court is very weak in setting forth any such methods. The passages which purport to deal with them ${ }^{35}$ contain a great many words, which give an impression of weight by their sound; but a careful attention to what is said must leave the reader in doubt as to whether any of the suggested methods were illegal or unfair methods of competition. One is impressed by the fact that in various forms the Chief Justice has simply reiterated the fact that the Standard Oil Company was large and successful. What he says boils down to size and success.

The whole case against the Standard Oil Company as made in the opinion of the court seems ta rest upon the defendant's attempt to monopolize by excluding others from the business. It is noticeable, however, that while the court talks about the intent to monopolize it does not specify that that intent is to be carried out by the use of illegal and unfair methods of competition. Yet that must be the assumption. An intent to succeed in business over rivals by the achievement of greater efficiency is not a crime or illegal at common law. The intent to monopolize, in the opinion of the court, arises only as a prima facie inference from size. The Chief Justice has used a great many and some very long sentences, but every time they are read carefully it will be found that they only assert that the Standard Oil Company was an organization of monstrously large size, and from this size, constantly referred to in various ways, the intent to monopolize is discovered. Nevertheless, it is said constantly that the intent to monopolize arises from size only as a prima facie inference or presumption. ${ }^{36}$

$$
\begin{aligned}
& 35-[1110,1111] . \\
& 36-\text { These passages occur at of }[1111] \text {. }
\end{aligned}
$$


\$127. The character of the organization of the Standard Oil Company of New Jersey with respect to whether it was a combination of competing units or even, properly speaking, a combination at all, requires attention.

The Standard Oil Company of New Jersey as reorganized in 1899 was the precise point of attack by the government. It was that organization which was dissolved by the decree. Of course, the decree did not permit the older organizations to step into the place of the Standard Oil of New Jersey, but required a dissolution which created new operating units.

The Standard Oil Company of New Jersey as organized in 1899 was plainly not a combination of competing units. True, they may have competed years ago and before the Sherman Act; but when the Sherman Act was passed in 1890 they were allor substantially all-already combined in the Standard Oil Trust and had ceased to compete, and the combination was legal so far as the federal law was concerned. It follows, therefore, that the Standard Oil of New Jersey was a combination of non-competing units which never had competed since the Sherman Act was passed. The elimination of competition between the units combined before the Sherman Act could not be urged as a ground of illegality under the Sherman Act. The legality or illegality of the Standard Oil Company of New Jersey must have been determined with reference to a single combination of non-competing units.

One may even doubt whether the Standard Oil of New Jersey was, properly speaking, a combination at all. When the Standard Oil Trust was formed in 1882 it was perfectly legal so far as the federal law was concerned. It represented an effort at organization in larger units than formerly, in accordance with the demands of the industrial revolution which was in progress. If then it was not illegal-and it was not so far as the federal law was concerned since there was no Sherman Act-surely it must be regarded as a normal and proper method of creating a unit in the industrial world. Hence at the time of the Sherman Act, the Standard Oil Trust was a normal, legal, and proper industrial unit. Only in a very popular sense was it still a combination. In dealing with it under the Sherman Act the court was simply bringing within its jurisdiction an industrial 
unit which was in existence and with respect to the legality of the original organization of which there could be no question.

\$128. The Standard Oil case, therefore, seems actually to hold that a unit which started as entirely legal and which grew as its business succeeded until it held a preponderant position in the business, but which all the time had the intent to monopolize, would be illegal when it came to occupy the preponderant position. In short, it appears actually to hold that any unit, however formed, which secures a perponderant position by means, however legal and proper, and which then acquires the intent to monopolize, becomes illegal. You do not need combination. You do not need a unit which is organized in a particular way. You do not even need the elimination of competition between the units. You do not need abnormal growth, so called. What you do need is merely a preponderant position in the business coupled with an intent to monopolize.

If $\mathrm{A}$, for instance, as an individual, manufactured low-priced automobiles; and had, by a process of the extraordinary growth of business, secured a preponderant position in the manufacture and sale of such cars; and if he should then, as an individual, start to use his power to exclude others by illegal and unfair methods of competition, or if there could be brought home to him the intent to monopolize by any other means, he would be carrying on business in violation of the Sherman Act. One does not quite see how equity could dissolve him; but indictment, and injunction against the committing of acts, would probably be ample remedies. Would a court of equity undertake to limit the size of his business and its output so as to reduce it to a unit not occupying a preponderant position? Could it split up his business and require parts of it to be sold? There are diffculties here, but the main proposition that the individual could violate the Sherman Act is sound.

\$129. In United States v. Pacific and Arctic Railway and Navigation Company ${ }^{37}$ the first and second counts of the indictment were sustained. They charged a combination between a steamship company, a wharves company, and a railroad which together occupied a preponderant position in the transportation 
service from ports in the United States to places in Alaska. This combination had the actual purpose to exclude others from this transportation service and to secure a monopoly, and attempted to carry out this purpose by unfair methods of competition. The carriers were connected and not competing, and there was therefore no application of the principle of the Northern Securities case; ${ }^{38}$ but the combination used its combined powers to exclude all other companies serving any part of the route in question. The railroad fixed local rates higher than the railroad's pro rata of the through rate which it made to members of the combination. The railroad then refused any through rate to steamship lines outside the combination. The wharves company charged more for freight if shipped by a line outside of the combination than it did for freight shipped on a line in the combination; and the wharves company had a monopoly of the wharfing facilities at the connecting port. The facts set up in the indictment clearly brought the case within the principle of the Standard Oil and Tobacco cases. ${ }^{39}$

\section{SECTION 5}

\section{COMPETITIVE METHODS}

\$130. In Anderson v. United States ${ }^{40}$ a mule of the Trader's Live Stock Exchange of Kansas City which provided that its members should not deal with any other yard trader unless he was a member of such exchange was sustained. Clearly the Trader's Exchange was competing with outside traders. It was trying to gain something by concerted action in refusing to deal with them. It seems to have been assumed that the exchange was not attempting primarily to force the outside traders out of business so as to secure the entire business for the members of the exchange, but was merely trying to hamper the outside traders sufficiently to bring them into the exchange where they would be subjected to standards of conduct which were assumed to be highly desirable.

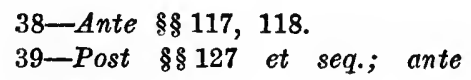


8131. In Montague v. Lowry ${ }^{41}$ we have an exclusive arrangement between the tile dealers of San Francisco and the manufacturers. The manufacturers were to sell only to those tile dealers in San Francisco and to no others. The plaintiffs were independent tile dealers in San Franciseo who were injured because they could not buy from the manufacturers who were in the association. The plaintiffs had a verdict of $\$ 500$ and a judgment under the Sherman Act for $\$ 1,500$. This was affirmed.

This case is subject to the comment that it does not appear clearly how large the combination of manufacturers was. Did it occupy a preponderant position in the tile manufacturing business? Probably it did. Very likely the evidenee disclosed the fact, but as it is a fact of the very utmost importance it is strange 'that the opinion of the court lays no emphasis upon it.42 If such an arrangement as this had been made with three manufacturers out of fifty, it would have been entirely unobjectionable. The plaintiffs would then have had ample opportunity to secure all the tile they wanted. It is only when the combination occupies a preponderant position and begins to connect up with collective units of dealers having also a preponderant position in the local situation that the prima facie inference of intent to use the power of the combination to exclude others by unlawful and unfair methods of competition arises, and the damage to the plaintiff caused by the exclusive contracts becomes a tort according to the common law.

\$132. In Eastern States Retail Lumber Dealers Association v. United States 43 the Government obtained an injunction restraining an association of retail lumber dealers from circulating among its members lists of wholesalers who were attempting to sell directly to consumers. ${ }^{44}$ It was conceded that the circulation of these lists was for the purpose of systematically

41-193 U. S. 38 (1904) [1049]. 42-Was this because Mr. Justice Peckham, who wrote the opinion of the court, was still under the influence of his dicta in the TransMissouri Freight Association and Joint Traffic Association cases and therefore was declining to make aize an element of illegality?
43-234 U. S. 600 (1914) [1157].

44 -It would seem that this was the only relief obtained. See United States v. Eastern States Retail Lumber Dealers Ass'n, 201 Fed. 581 (1912). 
causing the retailers not to deal with such wholesalers. What objection was there to this? Two groups of lumber dealers were in competition-the wholesalers and the retailers. Both were competing for the trade of the consumer. The wholesalers were really trying to break into the retail trade. It is of course in the public interest that they should compete. Very well, how may this competition be carried on? Is competition in price the only method of competition which the courts will permit? Certainly not. It happened that the retailers bought from the wholesalers. May not retailers then cease buying from the wholesalers for the purpose of defeating them in this competitive struggle? Would not such an act be exactly the same as the act of striking by employecs to compel their employer to refuse to recognize a rival group of employees working for the same employer and by this l,eans enable the strikers to triumph in their competitive struggle with the rival group of workers? If the employer started to work on his own job with his workmen and they struck to prevent him, the situation would be precisely the same as the action by the Retail Lumber Dealers. Such acts of striking, whether by employees against an employer ${ }^{45}$ or a Retail Dealers' Association against the wholesalers, ${ }^{46}$ are not by themselves illegal. Such acts have been regularly held to be legitimate methods of competition. They do not become illegal simply because they succeed in defeating the rival. Why? Because the public interest is, on the whole, better served by permitting this freedom of action to compete and the triumph of some competitors over others than it is by calling the strike in and of itself an unfair method of competition and illegal and tortious and by this means maintaining the status quo of existing competition.

\$133. The situation is altered as soon as one can say that the strikers or the blacklisters have a preponderant position in the field, and in consequence a power which makes it impossible for any rival to retaliate by the use of the same competitivo methods.47 Size ipso facto deprives the preponderant unit of the

45-Allen v. Flood, L. R. [1898] A. C. 1 [337], ante $\$ 96$.

46-Bohn Mfg. Co. v. Hollis, 54 Minn. 223 (1893) [473], ante \& 101.
47-Martell v. White, 185 Mass. 255 (1904) [478], ante § 102; Macauley v. Tierney, 19 R. I. 255 (1895) [487], ante \& 103. 
right to use methods of competition which, in the hands of smaller units, are legal. The result in the Lumber Dealers' Association case is to be supported on the ground that the retailers had sufficient size and preponderant position in the retail business so that they were deprived of a method of competition which was in and of itself lawful.

\$134. There are, however, two difficulties with the opinion of the court: First, the case as reported does not disclose any facts clearly indicating the size and preponderant position of the retailers in any market. One may guess from statements made that they constituted a large and powerful organization; but if this fact be left to guesswork, one may also hazard the surmise that the wholesalers would have been quite as powerful and perhaps more so if they had been organized and that the wholesalers were, therefore, potentially at least, quite able to retaliate by refusing to sell to any retailer who belonged to an association which blacklisted any member of the Wholesalers' Association. If such was the ease, it was not the business of the courts to say that the succeess of one competitor over another by the use of its power to refuse to deal with the other became a tort by the mere fact of success or because it was used for the purpose of successful competition in securing business. Secondly, it is not at all clear that the court concedes the right of any combination of retail lumber dealers, however insignificant in size, to act in concert in refusing to deal with wholesalers who sell to consumers direct. The opinion, while conceding that any one retail lumber dealer may refuse to deal with a wholesaler for any reason he pleases, intimates that two or more could not do so.48 This sounds like the proposition that a single

48- "A retail dealer has the un. questioned right to stop dealing with a wholesaler for reasons sufficient to himself, and may do so bocause he thinks such dealer is acting unfairly in trying to undermine his trade. 'But,' as was said by Mr. Justice Lurton, speaking for the court in Grenada Lumber Co. 7 . Mississippi, 217 U. 8. 433, 54 I. ed. 826 (1910), 'when the plaintifis in error combine and agree that no one of them will trade with any producer or wholesaler who shall sell to a customer within the trade range of any of them, quite another case is presented. An act harmless when done by one may become a public wrong when done by many acting in concert, for it then takes on the form of a conspiracy, and may be prohibited or punished, if the re- 
workman may strike for any reason he pleases, but that if two or more do so in concert it is an unlawful conspiracy. It is difficult to believe that a court unhampered by any statute or previous decision dealing directly with the point and reaching the problem today for the first time with full power to solve it by the application of the rule of reason could seriously put forward any such proposition.

Even, however, if the Supreme Court's decision in the Lumber Dealers' Association case be regarded as inconsistent with the results reached by common law courts, that does not mean that the Sherman Act specifies as illegal conduct which at common law was legal. It only means that the supreme court, in the exercise of its functions as a common law court, reaching results as common law courts are accustomed to do, obtained a different result from some other common law court; or that it exercised its prerogative to determine for itself what the common law was.

\$135. In Loewe v. Lawlor ${ }^{49}$ the secondary boycott by the hatters' union was held to be illegal because in violation of the Sherman Act and the employer recovered triple damages. The union members boycotted dealers throughout the country who handled the plaintiff's hats. This was done for the purpose of inducing such dealers not to handle the plaintiff's hats. The plaintiffs were damaged, and pressure was thus brought to bear upon them to compel them to unionize their shop and thus aid the National Hatters' Union in its competitive struggle with non-union labor. The preponderant position of the hatters' union in the United States was brought out by the number of employees in the union and by the fact that seventy out of eighty-two manufacturers in the hat business had acceded to the demands of the union to exclude non-union labor. In accordance with the common law, the secondary boycott by itself was a tort, 50 and might be expected to be held illegal under the Sherman Act; but the additional facts showing a preponderant position in the business of the boycotting hatters was sufficient to have made

sult be hurtful to the public or to the individual against whom the concerted action is directed.' ", 49-208 U.S. 274 (1908) [1166]; also Lawlor v. Loewe, 235 U. S. 522 (1915) [1191]. 50 -Ante \& 96. 
some acts torts which otherwise might have been lawful though rather strenuous methods of competition.

§ 136. In Thomsen v. Cayser ${ }^{51}$ a judgment for triple damages secured by a shipper against a combination of steamship lines which established a uniform freight rate and made a rebate to those shippers dealing exclusively with the combination was sustained. In the opinion of the court it was intimated that the combination employed

"' 'fighting ships' to kill off competing vessels which, tempted by the profits of the trade, used the free and unfixed courses of the seas, to paraphrase the language of counsel, to break in upon defendants' monopoly."

Here we have the same methods of competition which were found not to constitute a tort in Mogul Steamship Co. v. McGregor, Gow \& Co. ${ }^{52}$ Again we must ask whether these methods are per se illegal under the Sherman Act, regardless of the size and preponderant position of the combination, or does the court assume the existence of such size and preponderant position from its effectiveness or from any other evidence?

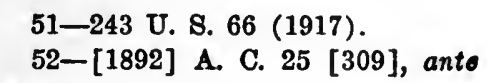

894. 


\section{CHAPTER IX}

\section{THE DICTA OF THE UNITED STATES SUPREME COURT}

\$137. So far as the actual decisions of the United States Supreme Court are concerned, they are consistent with the view that not every contract, combination, or conspiracy which is (however slightly) in restraint of trade according to the literal significance of those words, is illegal. The decisions of the courts are equally consistent with the view that the act condemns only contracts, combinations, and conspiracies in restraint of trade which are deemed illegal according to some standard which is outside the language of the act-either the standard of the common law or the standard of the rule of reason.

But when we look at the dicta of the court we find that originally there was much uncertainty in the choice to be made between the possible views.

\$138. In United States v. Trans-Missouri Freight Association ${ }^{1}$ the court, speaking by Mr. Justice Peckham, said: "the contract may be a restraint of trade, but still be valid at common law." The court thus intimated that the Sherman Act might hit restraints of trade which were valid at common law. ${ }^{2}$ There was no call for this statement and it has given rise to a great

$1-166$ U. S. 290 (1897) [826].

$2-[877]$ "A contract may be in restraint of trade, and still bo valid at common law. Although valid, it is nevertheless a contract in restraint of trade, and would be so described either at common law or elsewhere. By the simple use of the term 'contract in restraint of trade,' all contracts of that nature, whether valid or otherwise, would be included, and not alone that kind of contract which was invalid and unenforceable as being in unreason- able restraint of trade. When, therefore, the body of an act pronounces as illegal every contract or combination in restraint of trade or commerce among the several states, etc., the plain and ordinary meaning of such language is not limited to that kind of contract alone which is in unreasonable restraint of trade, but all contracts are included in such language, and no exception or limitation can be added without placing in the act that which has been omitted by Congress." 
deal of unnecessary discussion. For instance, the majority of the court having talked in the unnecessary way. just noted, the dissenting justices poured forth pages of dissenting opinion combatting this dictum. The result was that the majority were right in their decision, but wrong in this dictum. The dissent is right in criticising the dictum. The result is apparent disagreement as to the proper decision to be reached when, as a matter of fact, there is only disagreement as to an unnecessary statement of opinion.

§139. In the Northern Securities Case 3 four judges out of nine failed to state in their opinion the true ground for the decision, 4 and appeared to place the result reached by them on the ground that any merger of competing units (however insignificant) was illegal. 5 Four judges, therefore, scemed to support the view that the Sherman Act went far beyond the common law in holding acts illegal because in restraint of trade. Mr. Justice Brewer, while supporting the result reached by the court and furnishing in fact the decisive vote in favor of that result, repudiated the unnecessary language and dictum of the Trans-Missouri Freight Association Case, and asserted that the restraint to be illegal must be unreasonable. Mr. Justice Peckham agreed with Mr. Justice Holmes that the Northern Securities Company did not violate the Sherman Act; and it therefore became necessary for him to distinguish the actual decision in the TransMissouri Freight Association Case, in which he wrote the opinion of the court. This he permits Mr. Justice Holmes to do for him. Mr. Justice Holmes attempts to draw a distinction between combination by contract and combination by merger. ${ }^{6}$ In the Traffic Association cases the railroads stayed in the business and continued to operate their respective properties. There was still competition in service. By agreement they eliminated competition as to rates. In the Northern Securities Case they combined by merger and the placing of competing properties in the hands of a single new operating unit. This eliminated competition both as to rates and service. The elimination of com-

3-193 U. S. 197 (1904) [910].

4-Ante \&\&51, 117 et seq.

5-John C. Gray evidently so regarded the opinion: The Merger
Case, 17 Harv. L. Rev. 474, ànte

8118 , note 17.

$6-[957]$. 
petition was quite as effective, if not more so, than that which occurred by contract in the Traffic Association cases. It now seems impossible to condemn a combination by contract, such as was dealt with in the Traffic Association cases, and at the same time sustain a combination by merger, such as occurred in the Northern Securities Case.

\$140. It was entirely unnecessary for the decision in the Standard Oil Case ${ }^{7}$ that the court should attempt to say whether the Sherman Act prohibited every contract, combination, or conspiracy which was (however slightly) in restraint of trade, according to the literal meaning of that phrase, or whether it prohibited only illegal contracts, combinations, and conspiracies in restraint of trade-the illegality being determined by some standard outside the act, such as the standard of the common law or the standard of the rule of reason. On either theory the Standard Oil Company of New Jersey was illegal. Nevertheless, eight judges out of nine undertook, in a solemn dictum, to settle the matter in favor of the latter view.

$\S 141$. The court, in generalizing as to what was prohibited by the Sherman Act, referred to: ${ }^{8}$

"All contracts or acts which were unreasonably restrictive of competitive conditions, either from the nature or character of the contract or act, or where the surrounding circumstances were such as to justify the conclusion that they had not been entered into or performed with the legitimate purpose of reasonably forwarding personal interest and developing trade, but, on the contrary, were of such a character as to give rise to the inference or presumption that they had been entered into or done with the intent to do wrong to the general public and to limit the right of individuals, thus restraining the free flow of commerce and tending to bring about the evils, such as enhancement of prices, which were considered to be against public policy."'

Such a characterization is of course absolutely silent as to what specific acts are illegal. As to that matter, the phrases used are all quite circular and self-proving. A reference to acts which are "unreasonably restrictive of competitive conditions" still leaves undone the process of balancing interests in order to determine what features of a given situation are distinctive, and whether the balance is in favor of or against the validity of the

7-221 U. S. 1 (1910) [1072]. $8-[1096]$. 
acts in question. So where the court, in attempting further to specify what is a test of unreasonableness, says that the act would be illegal if "done with the intent to do wrong to the general public and to limit the right of individuals," it leaves us quite as much in the dark as before as to what is a "wrong" to the general public and what is "the right" of individuals. What the passage does clearly say is that the Sherman Act is not to be looked to for the purpose of determining what specific acts are prohibited; that the function of the act is merely to conduct the court into a given federal jurisdictional subject and there leave it to secure results according to some standard outside of the terms of the act itself.

\$142. Then the court undertakes to define what this standard is. It says : ${ }^{\circ}$

". . the provision [of Section 1 of the Sherman Act] necessarily called for the excrcise of judgment which required that some standard should be resorted to for the purpose of determining whether the prohibition contained in the statute had or had not in any giren case been riolated. Thus not specifying, but indubitably contemplating and requiring a standard, it follows that it was intended that the standard of reason which had been applied at the common law and in this country in dealing with subjects of the character embraced by the statute was intended to be the measure used for the purpose of determining whether, in a given case, a particular act had or had not brought about the wrong against which the statuto provided."

As to Section 2 of the act the court says: 10

'I. . . the criteria to be resorted to in any given case for the purpose of ascertaining whether violations of the section have been committed is the rule of reason guided by the established law . . ."

The court does not say that it adopts the common law as a standard, but rather that it adopts "the standard of reason which had been applied at common law." This means that the United States Supreme Court is admitted by the Sherman Act into an area of federal jurisdiction over interstate and foreign commerce to decide what contracts, combinations, and conspiracies, and what attempts to monopolize, are illegal; that in the exercise of

9-[1097].

Kales Sum. R. of T. $\rightarrow$
10-[1099]. 
this jurisdiction it is not guided by the language of the act nor bound by any adjudications of other courts; that it must, therefore, secure its results as any court does which is dealing with the common law when it reaches a problem upon which there is no binding decision. It must decide according to a certain technique of judicial reasoning practiced by judges sitting in courts administering the common law. With regard to contracts, combinations, and conspiracies in restraint of trade and attempts at monopoly, it must analyze the situation in question, balance the interests of the parties and the public, and reach a generalization as to what is prohibited and what is not-all for the purpose of determining whether the particular contract, combination, or conspiracy, or attempt to monopolize, in question, is legal or illegal. It must, in short, act as Lord Nottingham acted when he analyzed the limitations in the Duke of Norfolk's Case and reached a generalization which has become the basis for the modern rule against perpetuities.11 The Supreme Court of the United States might truthfully have said that it adopted the standard of the common law, but that since it was not bound by the decisions in other jurisdictions as to what the common law might be, it was the sole judge of that law for the purpose of applying the Sherman Act; and that while it looked to the common law decisions of other jurisdictions for aid and advice, it was its duty to approach all questions as to what the common law might be with that exercise of reason which was the very essence of the court's function in establishing a common law rule before anything had been settled by actual decision.

\$143. The court explained 12 that the Traffic Association cases only held that when an act was illegal because in restraint of trade it was useless to resort to various arguments and considerations in support of its reasonableness in order to justify it. This is the same as saying that after the interests have all been balanced and the decision is against the legality of the combination, it is useless to urge over again all those considerations which exist in favor of permitting the combination in order to upset the conclusion. If this is what the court had meant in the Traffic Association cases, it would have been easy enough to have 
so stated. If the court in the Traffic Association cases did not mean this-if it did mean what it certainly appeared to say, that the Sherman Act prohibited every contract, combination, or conspiracy which was (however slightly) in restraint of trade, according to the literal meaning of that phrase, so that the prohibition of the act would be broader than any common law rule of illegality - then it is overruled.

8144. In United States v. American Tobacco Co.13 the court, in dealing with the construction of the Sherman Act, said:

"Applying the rule of reason to the construction of the statute, it was held in the Standard Oil Case that as the words 'restraint of trade' at common law and in the law of this country at the time of the adoption of the Anti-trust Act only embraced acts and contracts or agreements or combinations which operated to the prejudice of the public interests by unduly restricting competition or unduly obstructing the due course of trade or which, either because of their inherent nature or effect or because of the evident purpose of the acts, etc., injuriously restrained trsde, that the words as used in the statute were designed to have and did have but a like significance."

This passage again clearly states that the Sherman Act only prohibits conduct in restraint of trade which is determined by the court, by the application of some standard outside the act, to be illegal. It is confusing, however, to say that this construction of the act is reached by the application of "the rule of reason." The phrase "rule of reason" has been used to describe the process by which the court determines what acts are illegal under the authority of the statute. It would be well to retain this usage exclusively and consistently. ${ }^{14}$

13-221 U. 8. 106,179 (1910) [1136].

14-In Eastern States Retail Lbr. Dealers' Ass'n 7 . United Btates, 234 U. B. 600 (1914)
[1162] the dicta of the Supreme Court in the Standard Oil and Tobacco cases are quoted with approval. 


\section{CHAPTER $\mathbf{X}$}

\section{THE CONSTITUTIONALITY AND VALIDITY OF THE SHERMAN ACT}

8145. Suppose the Sherman Act prohibits every contract, combination and conspiracy which is (however slightly) in restraint of trade according to the literal significance of those words, in accordance with the dictum of the court in the TransMissouri Freight Association Case. ${ }^{1}$ That would mean that some acts would be forbidden which were in restraint of trade but which at common law were legal and proper. If, however, the common law determined what acts in restraint of trade were legal or illegal on the balance of all the considerations affecting the parties and the public, the supposed interpretation of the Sherman Act would cause it to prohibit acts which on a balance of all the proper considerations were not contrary to the interests of the parties or the public. Such a construction would mean that the act would be a blow (incalculable in extent) to the freedom to do business. Would it then be "due process of law" under the Fifth Amendment? Might it not be quite as violent an onslaught upon the fundamentals of the social structure as the acts held void in the Lochner Case, ${ }^{2}$ the Adair ${ }^{3}$ and Coppage ${ }^{4}$ cases and the Upper Berth Case ${ }^{5}$ ? This is now a moot question because such a construction of the Sherman Act has been finally repudiated. It is worth noting, however, that the Supreme Court of the United States undertook to sustain the constitutionality of the Sherman Act even when it was inclined to adopt the construction assumed. ${ }^{6}$

1 -Ante $\$ 138$.

2-Lochner v. New York, 198 U. S. 45 (1905).

3-Adair v. United States, 208 U. S. 161 (1908).

4-Coppage v. State of Kansas, 236 U. S. 1 (1915).
5-Chicago, Milwaukee \& St. P. R. R. v. Wisconsin, 238 U. S. 491 (1915). See Due Process, the Inarticulate Major Premise and the Adamson Act, by A. M. Kales, 26 Yale Law Journal 519.

6-United States v. Joint Traffic 
\$146. Now suppose (as seems settled) the act prohibits only contracts, combinations, and conspiracies which are illegal because in restraint of trade-the illegality being determined by some standard outside the act-i. e., "the standard of reason which was applied at common law." Is the act valid? Certainly the act would not violate the Fifth Amendment. It would not fail to be "due process of law"; for, ex hypothesi, what is declared illegal by the act, should, on a balance of all the interests, be prohibited. ${ }^{7}$ But why is not the act void for uncertainty, or because it is a delegation of legislative powers to the court to define crime and acts which are prohibited by law?

\$147. If the statute is not void for uncertainty it must be because there is a sufficient standard to make the acts prohibited certain. In International Harvester Co. v. Kentucky ${ }^{8}$ the legislation in question failed for uncertainty because there was no standard at all. The standard of real value of the article sold by the combination as compared with the price asked was purely illusory. In the case of the Sherman Act, however, there is a standard in the fiat of the court itself applying the rule of reason as at common law. This is a real standard because it makes every act prohibited just as definite and certain as was every common law crime, or act held invalid because it was in restraint of trade, before the court had finally adjudicated the act to be a crime or to be illegal. Courts which are admittedly tied to the common law system could not say that a statute which, in defining crime or illegal acts, provided for the same degree of uncertainty-no more and no less-and the same basis of uncertainty which existed at common law before any authoritative determination had been made, was too uncertain to be valid. ${ }^{9}$

Association, 171 U. S. 505 (1898) [765].

7-Standard Oil Company v. United States, 221 U. S. 1 (1910) [780]: "But the ultimate foundation of all these arguments [against the constitutionality of the Sherman Act] is the assumption that reason may not be resorted to in interpreting and applying the statute, and therefore, that the statute unreasonably restricts the right to contract, and unreasonably operates upon the right to acquire and hold property. As the premise is demonstrated to be unsound by the construction we have given the statute, of course the propositions which rest upon that premise need not be further noticed."

8-234 U. S. 216 (1914).

9-Nash v. United States, 229 U. S. 373 (1913) [1152]. 
\$148. But if the source of uncertainty is the "standard of reason" applied by the court, why is not the act void because it is a delegation of power to define crime and illegal acts? Suppose, for instance, the act had in terms empowered the supreme court to determine what contracts, combinations, and conspiracies in restraint of trade were illegal; and that in so doing it was to exercise its reason and balance the interests of the parties and the public as the judges in common law courts did upon making a decision before any authoritative adjudication had occurred upon the subject dealt with. Would such an act be a delegation of legislative power to define crime or illegal acts? Clearly not. The legislation enacted would merely cast upon the court its centuries-old common law judicial function. The act would do no more than define a federal jurisdiction over interstate and foreign commerce into which it would conduct the court there to operate as common law courts regularly operate in reaching decisions. It would do no more than is effected where, by the settlement of a colony or a territory from a common law jurisdiction, the courts of the new jurisdiction begin to decide what is common law and to apply it on the ground that the settlers brought the common law with them..$^{10}$ The Supreme Court of the United States, when exercising its original jurisdiction in disputes between states, at once adopted the standard of reason which was applied at common law, and ealled the result interstate common law.11 Surely Congress can give to the federal courts the power which courts have exercised without any act of any legislature. The federal courts in certain classes of cases where they obtained jurisdiction on the ground of diverse citizenship have, under the doctrine of Swift v. Tyson, ${ }^{12}$ undertaken to apply what they conceive is the common law rule. Their common law rule not infrequently differs from the common law rule of the state where the action arose and where the case was

10-Railroad v. Keary, 3 Oh. St. 201, 205 (1854) ; Bloom v. Richards, 2 Oh. St. 387, 390 (1853). See also State v. Cawood, 2 Stew. (Ala.) 360,362 (1830). In Lyle v. Richards, 9 Serg. \& Rawle 322, 330 (1832) the court states that our ancestors "brought with them the common law in general, although many of its principles lay dormant, until awakened by occasion."

11-Kansas v. Colorado, 206 U. S. 46 (1907).

12-16 Pet. 1 (1842). 
tried. No acts of Congress conferred this power. ${ }^{13}$ By what rational process the federal courts secured it is still a mystery. ${ }^{14}$ If the federal courts can, in the exercise of their jurisdiction founded upon diverse citizenship, declare what is the common law, surely they can do the same thing in the jurisdiction conferred upon them by the Sherman Act with respect to restraints of trade in interstate and foreign commerce. Then we have the state statutes which declare generally that the common law shall be the rule of decision. We find cases attempting to describe what this means. ${ }^{15}$ But no one ever attempted to call such acts unconstitutional because they were a delegation of legislative power to the courts to define crime, or the rights or liabilities of the parties. The parallel between such acts and the Sherman Act is complete. Both alike conduct the courts into a given jurisdiction and then authorize them to act within that jurisdiction the way courts administering the common law have been accustomed always to act. The only difference is that the general statute adopting the common law is comprehensive as to subjects and territorial jurisdiction. The Sherman Act picks out a special jurisdiction- "interstate and foreign commerce"and then as to that gives the federal courts authority to act (as common law courts administering common law have been accustomed to act) only with reference to contracts, combinations, and conspiracies in restraint of trade, and monopolies, and attempts to monopolize.

13-Indeed, it seems to have been established contrary to the terms of the Judiciary Act, U. S. Stat. 1789, Chap. 20, paragraph 34, which provided that "the laws of the several states, except where the Constitution, pleadings, or statutes of the United States shall otherwise require or provide, shall be regarded as rules of decision in trials at common law in the courts of the United States in cases where they apply"; and under which it has been held that the rules of law determined by the decisions of the state as to the law of real property, for instance, shall be applied in the federal courts.

14-The Nature and Sources of the Law, John C. Gray, 535 et seq.

15-Williams จ. Miles, 68 Neb. 463 (1903); Lux v. Haggin, 69 Cal. 255 (1886); Sayward จ. Carlson, 1 Wash. 29 (1890). 


\section{CHAPTER XI}

\section{WHO MAY INVOKE THE APPLICATION OF THE SHERMAN ACT}

\$149. Of course the Attorney-General of the United States may invoke the application of the act by a bill in equity or indictment in the federal courts. The individual may also do so in a suit for triple damages under Section 7. But the stockholder of a corporation that could sue under Section 7 cannot, in his own name, sue for triple damages. 1 Nor can he sue in equity for triple damages even when the officers of the corporation refuse to do so and the corporation itself is made a party defendant.2 Such an action would deprive the defendant who had wronged the corporation of trial by jury in a suit for a penalty. His right should not be affected by the refusal of the officers of the corporation to accommodate the stockholder. The stockholder might attempt to secure a decree directing the corporation to sue, and if it failed to do so, or could not properly be trusted to do so, ordering the corporation to permit the plaintiff to sue at law in its name and on its behalf. Perhaps, in the suit by the stockholder against the corporation and the defendant alleged to have committed the damage, the court, after a preliminary investigation of the merits of the plaintiff's case and the existence of the refusal of the corporate officers to sue and want of justifieation for such refusal, might properly send the issue of the violation of the Sherman Act and the damages to a court of law for trial by jury.

\$150. How far may the individual apart from the suit for triple damages invoke the operation of the court under the Sherman Act? Of course, he cannot take the place of the AttorneyGeneral and institute such a suit as the government is authorized

1-Ames v. American Tel. \& Tel. Co., 166 Fed. 820 (1909) [1221].
2-Fleitmann v. Welsbach Co., 240 U. S. 27 (1916). 
to bring. ${ }^{3}$ The individual must in any case have a private right which is infringed by the conduct which under the Sherman Act is illegal. This usually means that he must have suffered some special damage-damage different from that suffered by the public at large.

\$151. Suppose, for instance, the complainant is a minority stockholder in a corporation, the majority of the stock of which is, illegally and in violation of the Sherman Act, being held by another corporation. Can there be any doubt that the minority stockholder can challenge the legality of that stockholding? Hardly. It is no answer that the government can do so or that the stockholder might sue for triple damages. The Sherman Act makes the stockholding generally illegal; and the lawful stockholder may challenge in equity the control and acts of the illegal holder of stock, ${ }^{4}$ just as he may where the stockholding is illegal at common law.5 His private right to be associated only with legal stockholders has been infringed; he has suffered the special damage required.

8152. Suppose the defendant's conduct in violation of the Sherman Act is a tort to the plaintiff for which he could recover triple damages. For instance, suppose, as in Loewe v. Lawlor, ${ }^{\circ}$ the defendant has practiced the secondary boycott against the plaintiff and thereby damaged him. Suppose also the damage is irreparable and the remedy at law-even for triple damages-is inadequate. Can the plaintiffs have relief by injunction? This question should be answered in the affirmative. No reason can be urged why the injunctive remedy is not available

3-Minnesota v. Northern Securities Co., 194 U. S. 48, 70, 72 (1904).

4-Bigelow v. Calumet \& Hecla Mining Co., 155 Fed. 869 (1907) [1195]; Shawnee Compress Co. $\nabla$. Anderson, 209 U. S. 423 (1908) [785]; Continental Securities Co. . Interborough Rapid Transit Co., 165 Fed. 945 (1908); de Koven v. Lake Shore \& M. S. Ry. Co., 216 Fed. 955; Geddes v. Anaconda Copper Mining Co., 222 Fed. 129 (1915);
Boyd v. New York \& H. R. Co., 220 Fed. 174 (1915); Union Pacific R. R. Co. v. Frank, 226 Fed. 906 (1915).

5-Dunbar v. American Telephone \& Telegraph Co., 238 IIl. 456 (1909); Harding v. American Glucose Co., 182 Ill. 551, 625.633 (1899).

6-208 U. S. 274 (1908) [1166]; Lawlor v. Loewe, 235 U. S. 522 (1915) [1191]. 
to prevent a tort merely because the tort is the creation of a statute, unless it can be said that the statutory remedies are exclusive. The cases which give the minority stockholder a right to proceed in his own name against the illegal stockholders indicate that the remedies provided by the statute are not exclusive. Furthermore, when it is remembered that the true function of the Sherman Act is not to make illegal any specifically described act, but merely to let the federal courts into a federal jurisdiction over interstate and foreign commerce there to exercise the common law court's function of deciding what contracts, combinations, and conspiracies in restraint of trade are illegal, and what monopolies and attempts to monopolize are illegal, there is reason enough for permitting all the remedial consequences of the court's action in finding certain acts to be illegal. The remedies provided by the statute are just those which the courts exercising the function of the common law courts could not grant. They are, therefore, in addition to the remedies which the court could grant if those special remedies had not been mentioned in the act. Hence, when under the authority of the statute the court finds that a tort has been committed, any remedy by injunction ordinarily available should be open to the plaintiff-with possibly the qualification that if triple damages may be recovered the complainant's bill for an injunction should make it clear that a judgment for triple damages is still an inadequate remedy at law. Recently, however, the supreme court in Paine Lumber Co. v. Neal, ${ }^{7}$ has taken a contrary view. ${ }^{8}$ The majority of the court, by Mr. Justice Holmes, merely expresses its conclusion. Four justices dissent. The dissenting opinion of Mr. Justice Pitney seems not to have been met or to be answerable. In view of Section 16 of the Clayton Act, the precise question involved is now of less practical interest. ${ }^{9}$

$7-244$ U. S. 459 (1917).

8-Following the inclination of the lower federal courts in Pidcock v. Harrington, 64 Fed. 821 (1894) [1219]; Blindell จ. Hagan, 54 Fed. 40 (1893); Greer Mills \& Co. จ. Stoller, 77 Fed. 1 (1896); Southern Indiana Express Co. v. Uniced
States Express Co., 88 Fed. 659 (1898); National Fireproofing Co. v. Mason Builders' Association, 169 Fed. 259 (1909). (This case is analyzed ante $\S 105$ to show that no tort had been committed.)

9-Post \&162. 
8153. Suppose the defendant, when sued upon a contract for the sale of goods, defends upon the ground that the seller exists in violation of the Sherman Act. Clearly the defense fails. The mere existence of the seller is not a special damage to the defendant or an infringement of any private right which he may have. The buyer is affected only in the same way that the public generally is affected. He cannot, therefore, raise the illegality of the seller's existence as a business unit. ${ }^{10}$ Suppose, however, the very contract of sale upon which the defendant is sued for the purchase price is itself illegal because one of a scheme of contracts by means of which the illegal combination is secured. In the Wall Paper Case these facts were held to constitute a defense. ${ }^{11}$ In the Corn Products Case 12 the decision in the Wall Paper Case was approved and distinguished on the ground that the holding there "was rested exclusively upon elements of illegality inhering in the particular contract of sale in that case." In the Corn Products Case the contract sued upon was, taken by itself, legal. It did not appear that the scheme of contracts of which it was a part effected the illegal combination; but only that the seller which made the contract was an illegal combination, and sought to perpetuate its power by the form of contract in question. This was insufficient, and distinguished the case from the Wall Paper Case.

10-Connolly $\nabla$. Union Sewer Pipe Co., 184 U. S. 540 (1902) [1199].

11-Continental Wall Paper Co. v. Voight \& Sons Co., 212 U. S. 227 (1909) [799]. In the same way, where a long distance telephone company attempted to enforce specifically an exclusive con. tract for connection with local exchanges, and the exclusive contract was part of a scheme of contracts, and all were illegal at common law and under the Sherman Act, these facts constituted a complete defense: United States Telephone Co. v. Central Union Telephone Co., 202 Fed. 66 (1913).

12-Wilder Mannfacturing Co. v. Corn Products Co., 236 U. S. 165 (1915) [1211]. 


\title{
PART 3
}

\section{THE FEDERAL TRADE COMMISSION LAW AND THE CLAYTON ACT}

\author{
CHAPTER XII

\section{THE FEDERAL TRADE COMMISSION LAW ${ }^{1}$}

§ 154. Section 5 of the Federal Trade Commission Law provides "that unfair methods of competition in commerce are hereby declared unlawful."

It is clear that this, like the Sherman Act, merely operates as a general license to the federal courts, when cases are presented within the federal jurisdictional subject of interstate and foreign commerce, to declare or make the law as to what are illegal methods of competition and what are not, according to the usage customarily adopted by common law courts, $i$. e., by applying the rule of reason.

The first doubt which arises is whether the phrase "unfair methods of competition" embraces all illegal methods of competition, that is, all unjustifiable torts committed in the course of competition, or whether it confines the jurisdiction of the federal courts to passing upon the legality or illegality of those methods of competition which are employed by units occupying a preponderant position in the business. The fact is that "unfair competition" is a phrase which has had a certain currency to indicate acts of competition which were torts without regard to the size of the defendant. "Unfair methods of competition," on the other hand, is a more recent phrase which has been associated largely with the acts of competition which are torts only when employed by units occupying a preponderant position in the business.

1-Pub. No. 203-63rd Cong. 
If this latter meaning of "unfair methods of competition" be adopted, then it is doubtful whether Section 5 of the Federal Trade Commission Act adds much to the federal law. "Unfair methods of competition," in the sense of methods which were illegal because employed by a unit occupying a preponderant position in a business, were under the Sherman Act torts to the one damaged, and might be made the basis of a recovery for three-fold damages or for a dissolution suit against the unit using them. It is difficult to conceive of an "unfair method of competition" by a unit occupying a preponderant position in the business which is not involved in a contract, combination or conspiracy in restraint of trade, or an attempt to monopolize. 


\section{CHAPTER XIII}

\section{THE CLAYTON ACT ${ }^{1}$}

\$155. The Clayton Act in terms forbids combinations by stock ownership in other corporations ${ }^{1 \mathrm{a}}$ and by interlocking directors. $^{2}$ The provisions forbidding interlocking directors are quite specific. The owning of stock in other corporations seems to be forbidden only when its. effect may be "to substantially lessen competition" between the corporations or "to restrain such commerce in any section or community, or tend to create a monopoly of any line of commerce." This would seem to throw the whole matter into the hands of the court to decide as common law courts are accustomed to decide cases. The words of the act hardly add anything to what the court could do under the Sherman Act.

\$156. Two unfair methods of competition are indicated and declared to be unlawful-local price-cutting ${ }^{3}$ and exclusive (or tying) contracts of sale or purchase. ${ }^{4}$ Both acts are declared unlawful only when their effect is "to substantially lessen competition or tend to create a monopoly in any line of commerce." Does this do any more than leave it to the courts, acting as common law courts were accustomed to proceed, to make or declare what act of local price-cutting or what exclusive contract would be a tort? If not, the fact that the local price-cutting or exclusive contract was used by a unit occupying a preponderant position in the business would be an important, if not a decisive, element in making the tort. What other elements might be sufficient to make the act of local price-cutting or exclusive contract a tort to the party damaged, it is not attempted here to specify; but whatever they may be, it is submitted that they are the same under the Sherman Act as they are under the Clayton Act.

1-Pub. No. 212-63rd Cong.

1a-Sec. 7 [1231].

2-Sec. 8 [1232].
3-Sec. 2 [1229].

4-Sec. 3 [1229]. 
8157. The most discussed sections of the Clayton Act have been the so-called labor provisions-Sections 6 and 20.5 Section 6 commences with the declaration "that the labor of a human being is not a commodity or article of commerce." No labor organization or its acts can, therefore, be brought within the jurisdiction conferrred by the Sherman Act by reason of the fact that labor units pass from one state to another. But the Clayton Act does not in the least prevent the same organization or the acts of such organization from coming within that jurisdiction because they affect interstate commerce in commodities as in Loewe v. Lawlor. ${ }^{6}$ As labor organizations and the acts of such organizations which are attacked for illegality under the Sherman Act practically always affect interstate commerce in a commodity, the first sentence of Section 6 of the Clayton Act is not of practical value in exempting labor organizations and their acts from the possibility of being illegal under the Sherman Act.

8158. Section 6 goes on to provide: "nothing contained in the antitrust laws shall be construed to forbid the existence and operation of labor, agricultural, or horticultural organizations, instituted for the purposes of mutual help and not having capital stock or conducted for profit, or to forbid or restrain individual members of such organizations from lawfully carrying out the legitimate objects thereof." This is merely a restatement of the common law and presumably the law under the Sherman Act-that labor organizations "for the purposes of mutual help" are not per se illegal but are on the contrary lawful. Nor is there anything illegal at common law or under the Sherman Act in individual members of "such organization" (i. e., a legal organization "for the purposes of mutual help") "lawfully carrying out the legitimate objects thereof." ?

8159. The last clause of Section 6 adds nothing. It simply reiterates what is the common law and the law presumably under the Sherman Act that "such organizations [i. e., such as are

5- $[1230,1241]$. See an excellent note by Conrad E. Snow, 30 Harv, L. Rev. 632.

6-208 U. 8. 274 (1908) [1166];

Lawlor v. Loewe, 235 U. B. 522

(1915) [1191]. 7-86e opinion of Mr. Justice Pitney in Paine Lumber Co. v. Neal, 244 O. 8. 459 (1917). 
lawful and organized for purposes of mutual help] and the members thereof" shall not "be held or construed to be illegal combinations or conspiracies in restraint of trade under the antitrust laws."

The care with which Section 6 affirms the legality of organizations and acts of labor which were valid at common law and therefore valid under the Sherman Act, raises the inference very clearly that labor organizations and the acts of such organizations which, by reason of their being not merely for mutual help, but for the purposes of monopoly and to exclude others from the labor market, were illegal at common law and under the Sherman Act are still illegal under the Clayton Act.

$\$ 160$. Section 20 enumerates a list of specific acts which it provides shall not "be considered or held to be in violation of any law of the United States." This list does not include the "secondary boyeott," which was a tort at common law 8 and under the Sherman Act. ${ }^{9}$ The list does include a number of acts which, taken by themselves alone, were clearly lawful at common law and may be assumed to have been lawful also under the Sherman Act-such as: "terminating any relation of employment," and "ceasing to perform any work or labor." This points to the strike. Mere striking, however, has never been illegal at common law; and it may be assumed that it is not so under the Sherman Act. In the same list of acts is mentioned "ceasing to patronize or to employ any party to such dispute, or from recommending, advising or persuading others by peaceful and lawful means so to do." This refers to the direct boycott, which is legal at common law ${ }^{10}$ and presumably so under the Sherman Act. "Paying or giving to or withholding from any person engaged in such dispute, any strike benefits or other moneys or things of value ;" or "peaceably assembling in a lawful manner, and for lawful purposes;" or "doing any act or thing which might lawfully be done in the absence of such dispute by any party thereto," are acts which are certainly, by themselves alone, lawful and unobjectionable at common law or under the Sherman Act. The moment, however, the acts

8-Ante 897.

10-Ante 896 .

$9 \longrightarrow$ Ante $\$ 135$. 
enumerated are used by a combination of labor units occupying a preponderant position in the market with the purpose of excluding others from that market-thereby achieving or attempting to achieve a monopoly-they cease to be the acts to which the statute refers. They become acts of an entirely different character and effect. The combination and its acts are illegal at common law and presumably so under the Sherman Act. Section 20 of the Clayton Act contains no word which saves them from that illegality.11

\$161. The following acts mentioned in the enumeration of Section 20 are the only ones which have not yet been commented upon: "recommending, advising, or persuading others by peaceful means so to do" (i. e., strike); or "attending at any place where any such person or persons may lawfully be, for the purpose of peacefully obtaining or communicating information," or "peacefully persuading any person to work or to abstain from working." If these acts were in and of themselves alone, without any localized monopoly purpose, illegal at common law and under the Sherman Act, then this section of the Clayton Act has made them legal. But that does not neces-

11-Observe the limitation put upon the application of sec. 20 by Mr. Justice Pitney in his dissenting opinion in Paine Lumber Co. v. Neal, 244 U. S. 459 (1917). He says: "It [ 820$]$ refers only to cases "between an employer and employees, or between employers and em. ployees, or between employees, or between persons employed and persons seeking employment, involving, or growing out of, a dispute concerning terms or conditions of em. ployment.' These words evidently relate to suits arising from strikes and similar controversies, and the committee reports upon the bill bear out this view of the scope of the section. But this is not such a suit. There is no relation of employer and employee, either present or prospective, between the parties in

Kales Sum. R. of T.-10 this case. Defendants who are em. ployees are in one branch of in. dustry in New York City; complainants are employers of labor in another branch of industry in distant states. Nor is there any dispute between them concerning terms or conditions of employment.", Why, however, was there not a disputo between the defendants, who were " persons employed," and the non-union workers who were "percons seeking employment" from the complainants? The former wanted to triumph in the competitive struggle against the latter. Why was not this dispute between them "concerning the terms or conditions of employment," i. e., whether the non-union men should be employed unless they joined the union? 
sarily mean that when these same acts are done with the localized monopoly purpose of bringing every person who would wish to work at a particular place into an organization which has for its object to prevent any member from working at that particular place, and when this purpose has been so far carried out that the organization which seeks to promote it occupies a preponderant position in the labor field serving that particular shop or place, ${ }^{12}$ such an organization and its acts of peaceful picketing are valid under the Clayton Act. Under such circumstances the acts in question have become quite different from those enumerated in Section 20. They have an entirely different significance by the addition of the monopoly purpose. \$162. Section 16 of the Act ${ }^{13}$ establishes the individual's right to injunctive relief as to all acts which are illegal and tortious under the Sherman Act or the Clayton Law where irreparable damage is threatened and the remedy at law is inadequate. ${ }^{14}$ 


\section{PART 4. \\ PATENTS AND COPYRIGHTS}

\section{CHAPTER XIV}

\section{EFFECT OF PATENTS AND COPYRIGHTS}

\$162a. A patentee is given by law the exclusive right, for a limited period, to "make, use, and vend" the invention, or license others to do so.' The holder of a copyright is given the "sole right and liberty of printing, reprinting, publishing, and vending" the copyrighted article for a term of years. ${ }^{2}$

§163. These grants of privileges by Congress are, however, subject to the legislative power of the state to some extentat least in the absence of any more explicit action by Congress. Thus the right given by letters patent to vend a patented improvement for burning oil was subject to the legislative power of a state which condemned the device as dangerous. ${ }^{3}$ So the existence of the Bell Telephone and subsequent telephone patents, which the Central Union Telephone Company was entitled to use in Indiana, did not avoid an act of the Indiana legislature providing for the regulation of rates to be charged by telephone companies. 4

8164. An important question which has arisen under the Patent and Copyright Acts is this: How far may the sale of or the license to use, the patented article, or the sale of a copyrighted article, be made subject to conditions or stipulations which, if not adhered to, will avoid the license or the sale and cause the continued use to be an infringement?

1-Rev. Stats. 84884 .

2-1 Stat. at Large by Peters, chap. 15, p. 124. See also, R. B. 4952; Act Mar. 4, 1909, c. 320,
3-Patterson v. Kentucky, $97 \mathrm{U}$. 8. 501 (1878).

4-Hockett v. State, 105 Ind. 250, 257 (1885).

\section{1.}


\$165. When, for instance, the patentee of the fundamental Bell telephone patent, which gave to the patentee a monopoly of the telephone business down to 1893, leased telephone instruments to telephone companies, it attempted to impose the restriction that the instrument should not be used by telegraph companies other than the Western Union. When telegraph companies other than the Western Union attempted to compel the Bell Telephone Company to render service, they were met with the defense that this was forbidden by the stipulation and conditions of the license and lease in question. This defense failed. 5 When the instruments were put into use, by lease or license, in a given public service business, the conduct of the business was required to be in compliance with the rules of law relating to that business-one of which was that all members of the public were entitled to be served without discrimination. The license to use the invention could not be so restricted as to interfere with this rule.

$\S 166$. More recently, attempts have been made to sell or license the use of a patented article with a stipulation that the vendee or licensee, and those who take from them, shall use, with the patented article, only certain unpatented accessories sold by the vendor or licensor. ${ }^{6}$ Licenses have provided, both as to patented articles and copyrighted articles, that they shall not be resold by the vendee or licensee or anyone taking from

5-State v. Bell Telephone Co., 36 Oh. St. 296 (1880); Commercial Union Telegraph Co. v. New England Telephone \& Telegraph Co., 61 Vt. 241 (1888); Missouri v. Bell Telephone Co., 23 Fed. 539 (1885); State ex rel. Postal Telegraph Cable Co. v. Delaware \& Atlantic Tel. \& Tel. Co., 47 Fed. 633 (1891); Delaware \& Atlantic Tel. \& Tel. Co. v. Delaware, 50 Fed. 677 (1892); Bell Telephone Company v. Com. monwealth, 3 Atl. 825, 827 (Pa. 1886); Chesapeake \& Potomac Telegraph Co. v. Baltimore \& Ohio Telegraph Co., 66 Md. 399, 416 (1886), 7 Atl. 809 (1887); State v. No- braska Telephone Co., 17 Neb. 126, 22 N. W. 237, 239 (1885); Postal Cable Telegraph Co. v. Cumberland Telephone \& Telegraph Co., 177 Fed. 726 (1910); Bement v. National Harrow Co., 186 U. S. 70 (1902) (semble); Heaton-Peninsular Button Fastener Co. v. Eureka Specialty Co., 77 Fed. 288 (1896) (semble); Metropolitan Trust Co. v. Columbus Co., 95 Fed. 18 (1899) (semble).

6-Henry v. A. B. Dick Co., 224 U. S. 1 (1912); Motion Picture Patents Co. v. Universal Film Manu. facturing Co., 243 U. \$. 502 (1917). 
them for less than a certain price. In suits based upon the Patent and Copyright Acts to enjoin the use of the patented or copyrighted article where these stipulations have been violated by remote holders with notice the United States Supreme Court has decided against both the patentee and the holder of the copyright. 8 These cases proceed primarily upon a construction of the Patent and Copyright Acts-namely, that the right to "vend" or "license". does not include the right to place upon the use by the licensee or vendee or others the conditions or restrictions in question. Underlying this, however, is the idea that there is something contrary to public policy in such conditions and stipulations; that they are, apart from any question of patents or copyrights, subject to condemnation because they are illegal restraints of trade or attempts at monopoly; and that the right to "vend" and "license" under the Patent Act and the right to "vend" under the Copyright Act must be subject to the further rule that no stipulations or conditions shall be attached to the sale or license of the patented article which would be illegal if attached to a non-patented or non-copyrighted article. An effort has already been made elsewhere to show that there is, upon a proper balancing of all the interests, no ground for holding the stipulations or conditions in question void when attached to an unpatented or uncopyrighted article. ${ }^{9}$

\$167. How far does a patent which controls the carrying on of a given business during the life of the patent justify a combination of units in that business which, except for the patent, would be illegal ? 10

\$168. It is safe to say that a patent will not justify a combination which is arranged to extend beyond the life of the

7-Bobbs-Merrill Co. v. Straus, 210 U. S. 339 (1908); Bauer จ. O'Donnell, 229 U. 8.1 (1913); Straus $\nabla$. Victor Talking Machine Co., 243 U. B. 490 (1917).

8-See cases cited supra notes 6 and 7 except Henry v. A. B. Dick Co., 244 U. 8. 1 (1912); which 8ustained the suit of the patentee, but is now overruled.

9-Ante $8833-39,44$ et seq.
10-Bement v. National Harrow Co., 186 U. S. 70 (1902) [1246] is often cited in this connection; but it does not in the least touch the problem, because only a single contract was involved. The record did not disclose any combination for the court to pass upon, and the single contract before the court was unobjectionable even if there had been no patent. 
patent.11 It seems quite as clear that if the control of the business is secured by the union or purchase of competing patents, it will not only not be justified, but an additional ground for illegality will exist. ${ }^{12}$ Since each patent gives the patentee a monopoly for seventeen years of the use and disposal of his invention, the field is absolutely closed to all others. It follows that the union of the only two properties which can be used to carry on a given business would make an actual monopoly. A union of two out of three or even a union of any number out of any other number would produce an illegal attempt at monopoly. The right to vend or license the use of an invention is subject to the general rules of law against monopoly to this extent, at least: that after property in an invention has been created and an exclusive privilege of vending or licensing given, it must, like other property, be kept out of combinations with other properties which constitute a monopoly or an attempt at monopoly in the business.

$\S 169$. If the patents or copyrights cannot be said to be of so fundamental a character as to exclude others from the business, they can hardly be used to justify a combination of competing units which has a preponderant position and an intent to monopolize by excluding others by unfair and illegal methods of competition. ${ }^{13}$

\$170. Suppose a single fundamental patent gave to the patentee a monopoly of doing a given business for seventeen years. Would that fact justify the combination, limited to the life of the fundamental patent, of units in the business which

11-Strait $\nabla$. National Harrow Co., 18 N. Y. S., 224 (1891).

12-Blount Mfg. Co. v. Yale \& Towne Mfg. Co., 166 Fed. 555 (1909); National Harrow Co. v. Hench, 83 Fed. 36 (1897); National Harrow Co. $\nabla$. Hench, 84 Fed. 226 (1898); United States v. New Departure Mfg. Co., 204 Fed. 107 (1913); Vulcan Powder Co. v. Hercules Powder Co., 96 Cal. 510 (1892) ; State v. Creamery Package Mfg. Co., 110 Minn. 415 (1910).
13-Straus v. American Publishers Association, 231 U. S. 222 (1913) [1273].

Where, however, the patents are not competing but are supplementary to each other-all being used together for the purpose of manufacturing a given commodity-there is no objection to the assembling in a single manufacturing unit many valuable patents: United States v. Winslow, 227 U. S. 202 (1913). 
would otherwise be illegal solely because it was an attempt to monopolize?

8171. In Standard Sanitary Manufacturing Co. v. United States ${ }^{14}$ it appeared that the business of manufacturing enamel ironware had been carried on by many competitors when the Arrott patent was issued which provided for so superior a process that it controlled the business. Competitors attempted to compete, but the effectiveness of the patent was such that the great majority were forced into a combination which was effected by license contracts to use the patents. These license contracts provided, among other things, for the elimination of all competition between the units combined so far as the fixing of prices was concerned. The United States Supreme Court held that the combination was without justification. The Patent Act which gave an exclusive right to vend or license the article patented did not give any special privilege to use that right for the ulterior purpose of forcing competitors into a combination which except for the patent would be illegal.

\$172. Suppose there had been no one at all in the business when the invention was made-as in the case of the telephone. Suppose the holders of a single fundamental telephone patent which gave a monopoly of the telephone business had organized that business for the period of the life of the patent as a combination of operating units, each a separate and distinct corporation, with separate and distinct bodies of stockholders with all competition between them eliminated under the terms of the license contract to use the patent. Would such a combination have been legal? Could a distinction be made between the using of a fundamental patent to suppress a competition which existed before the patent and to force those units which had previously competed into a combination, and the using of a existed but which was organized on the basis of combining sepfundamental patent to create a business which had not before arate units which were not premitted to compete?

$14-226$ ర. 8. 20 (1912) [1136]. 



\section{INDEX}

\section{[REFERENCES ARE TO SECTIONS]}

\section{ACCESSORIES}

contracts to force use of

in general, $41-47 \mathrm{~b}$.

under Patent and Copyright Acts, 164-166.

ADDYSTON PIPE CASE, 66.

as a construction of Sherman Act, 123.

AGREEMENTS (seo CoNTRACTS).

\section{AMERICAN CAN COMPANY}

abandons excluding practices, 88.

\section{AMERICAN TOBACCO COMPANY}

Brandeis' views on, 77.

power of endurance of, 77 .

Tobacco Case discussed, 51.

Tobacco Case quoted, 144.

rule of reason applied in Tobacco Case, 144.

Tobacco Case compared with Standard Oil Case, 126, 129.

\section{ANTI-TRUST LAWS}

United States (sce Sherman Act, Clayton Act, and Federal Trade Comassion Law).

Kentucky, 147.

\section{APPRENTICE}

restrictive contracts by, 2-5.

ARROTT PATENTS, 171.

\section{ATTORNEY-GENERAL}

power to invoke Sherman Act, 149.

\section{ADCTION}

combination of bidders at, 49 n.7, 100 . 
AUTOMOBILES

[REFTEBENCES ARE TO SECTIONS]

illustration of manufacturer of low-priced, 128.

BANKERS

combinations of, 53 .

BARBER SHOP

operated for spite, 107a.

BELL TELEPHONE COMPANY

patents, 40 .

skill of engineers, 78 .

also see Telephone Companims.

BLACKLIST, 100.

as method of trade competition, 106, 132-134.

\section{BOYCOTT}

secondary boycott in general, 97.

as method of trade competition, 101, 106.

under Clayton Act, 160, 161.

under Sherman Act, 135, 152.

BRANDED GOODS

fixing prices of on resale, 31-40.

BRANDEIS, LOUIS D.

views on closed shop, 83.

views on economic effect of mere size, 74-81, 83, 89 .

views on extortionate prices, 79 .

BREWER, MR. JUSTICE

opinion in Northern Securities Case, 118, 139.

\section{BRICKLAYERS}

jurisdictional dispute of, 105.

\section{BUTCHERS}

combination by, 95 .

see Quinn v. Leathen, 97.

CARRIERS (seo RAILROADS).

CLAYTON ACT, 155-162.

combination by stock ownership forbidden, 155 .

exclusive contracts of purchase and sale under, 156. 


\section{[RIFIRENCES ARI TO BECTIONS]}

CLAYTON ACT-Continued.

interlocking directors forbidden, 155.

labor provisions of, 157-161.

local price-cutting forbidden, 156.

secondary boycott under, 160, 161.

Section 6 of, 157-159.

Section 16 of, 162.

Section 20 of, 160, 161.

CLOBED SHOP

in general, 98, 99.

Brandeis' views on, 83.

as tending toward monopoly, 83.

COERCION

a form of unlawful competition, 50 .

\section{COMBINATIONS}

see Table of Contents, especially chap. V.

by exclusive contracts of sale and purchase, 26-30.

by stock ownership, forbidden by Clayton Act, 155.

of bidders at public auction, 100.

of publio utilities, 51 .

of railroads, 51 .

of units controlling natural resources, 52.

of units operating under franchises, 51.

restrictive contracts accompanying, 18.

which fix price on resale, 71 .

\section{COMMON LAW}

restraint of trade at, 1-107.

\section{COMPETITION}

cutthroat, 17.

excessive, 22.

\section{CONPETITIVE METHODS}

in general, 93-107.

equitable relief against (see EQUTrT).

under Sherman Act, 130-136.

under Trade Commission Law, 154.

used by live stock exchange, 130 .

specific methods

blacklist, 100, 106, 132-134.

boycott (see BoycoTT). 


\section{INDEX}

\section{[REFERENCES ARE TO SECTIONS]}

COMPETITIVE METHODS-Continued.

closed shop, 83, 98, 99.

coercion, 50.

competition out of spite, 107a.

contracts by apprentices, 2.5 .

contracts to fix price on resale (see Contracts to, ETC.).

contracts to force use of accessories (see Contracts to, ETO.).

dumping, 87.

exclusive agencies, 26-30.

exclusive contracts of sale and purchase, 26-30, 115, 156.

fighting ships, 136.

fraud, 50.

inducing breach of contract, 50 .

intimidation, 50.

leaders, 31-40, 104, 106.

libel, 50.

local price-cutting (see Price-Cutting, Local).

picketing, 100.

price-cutting by department stores, 36 .

rebates, 50.

secondary boycott (see BoycotT).

secret combination of bidders, 49 n.7.

self-imposed fine, 102.

simulated competition, 49 n.7.

strike (see STRIKE).

threat to strike, 96,97 .

tying contracts, 26-30, 115, 156.

\section{CONSIDERATION}

in contracts not to compete, 4,7 .

CONTRACTS, EXCLUSIVE (see CONTRACTS Not to COMPETE).

CONTRACTS NOT TO BID AT AUCTION, 49 n.7, 100.

\section{CONTRACTS NOT TO COMPETE}

see Table of Contents, chaps. I-III.

accompanying a combination, 18.

also see Combinations.

accompanying the sale of a business to a competitor, 16-22.

also see Combinations.

accompanying the sale of a business not to a competitor, 6-15.

accompanying the sale of property, the business not being sold, 23-25. after death of promisee, 3 .

apprentice's, 2-5. 


\section{[REMRENCMS ARE TO SECTIONS]}

CONTRACTS NOT TO COMPETE-Continued.

consideration for, 4.

contracts not to bid at public auction, 49 n.7, 100.

divisibility of, 14.

enforcement in equity (see EQTITY).

exclusive contracts of sale and purchase.

in general, 26-30.

under Clayton Act, 156.

under Sherman Act, 115.

in foreign countries, 10,15 .

mere contracts to refrain from doing business, 1 .

partners', 18.

scope of contract

in general, 11-14, 18, 23.

broader than master's business, 2 .

broader than seller's business, 6, 10-14, 18, 23.

enforcement in equity after promisee's business ended, 24 .

geographical limitations, 2, 6, 10-15, 20.

time limitations, 13, 14, 24.

under Sherman Act, 113, 114.

when plant is left idle, 20-22.

where promisee not interested in the business, 1 .

CONTRACTS TO FIX RESALE PRICE, 31-40, 47a, 47b.

under Patent and Copyright Acts, 164-166.

under Sherman Act, 116.

when made by a combination, 71, 104, 106.

CONTRACTS TO FORCE USE OF ACCESSORIES, 41-47b.

under Patent and Copyright Acts, 164-166.

Copyrights (see Patents and Copyrights).

CORN PRODUCTS CASE

distinguished from Wall Paper Case, 153.

\section{CORNERS}

of natural resources, 52 .

of skill and efficiency, 78.

COVENANTS (see Contracts). covenants running with the land, 25.

\section{CURRYCOMBS}

contract to force use of on mule sold, $44,116$. 


\section{INDEX}

\section{[REFERENCES ARE TO SECTIONS]}

\section{CUTTHROAT COMPETITION, 57.}

DANBURY HATTERS' CASE, 135.

injunctive relief in similar case, 152.

DAY, MR. JUSTICE

opinion in Cash-Register Case, quoted, 78 n.62.

DEPARTMENT STORES

price-cutting by, 36 .

DIVISIBILITY OF CONTRACTS NOT TO COMPETE, 14.

DIVISION OF TERRITORY, 53 n.18.

DOCTORS

sale of business by, 13 .

\section{DRUGGists (see Pharmacists).}

\section{DUE PROCESS OF LAW}

effect of on construction of Sherman Act, 145-148.

Sherman Act more clearly due process than hours and wage-fixing legislation, 73.

protects freedom of economic action, 56, 59 .

DUMPING, 87.

ENDURANCE OF LARGE COMPANY, POWER OF, 77.

EQUTTY, RELIEF IN

equitable servitudes

in chattels in general, $47 \mathrm{a}, 47 \mathrm{~b}$.

contracts to keep up price on resale, 31-40.

contracts to force use of accessories, 41-47.

in land, 24, 25.

to enforce covenants by buyer of property, 24, 25 .

against violation of Sherman Act, 152.

against violation of Clayton Act, 162.

EXCESSIVE COMPETITION, 57.

EXCLUDING PRACTICES AND PURPOSES

as test of illegality of a combination, 48-92.

seo COMPETITIVE METHODS. 
INDEX

[REFRRENCES ARE TO SECTIONS]

exclusive agencies (see Exclusive Contracts or Sali and PUrCrASE).

EXCLUSIVE CONTRACTS OF SALE AND PURCHASE

at common law, 26-30.

under Clayton Act, 156.

nnder Sherman Act, 115.

FEDERAL TRADE COMMISSION LAW, 154.

Fifth AMENDMENT (see Due Process or Law).

FIGHTING SHIPS, 136.

FOREIGN TRADE

restrictive covenants covering, 10, 15.

FORFEITURE ON ALIENATION (see Restraint ON ALIENATION).

Fourteenth amendment (see Due Process or Law).

\section{FRANCHISES}

combinations of units operating under, 51 .

efffect of under Sherman Act, 117-122.

exclusive contracts with companies dependent on, 30 .

in Standard Oil Case, 126 n.34.

FRAUD

a form of unlawful competition, 50.

FRONTIER, SOCIAL STRUCTURE OF, 89.

GRAY, JOHN C.

case of the three Jerseymen, $118 \mathrm{n} .16,17$.

on Northern Securities Case, 118.

"Powers in Trust"' quoted, 82 n.67

"The Merger Case," 118 n.16, 17, 139 n.5.

“The Nature and Sources of the Law," 148 n.14.

\section{GROCERIES}

combination of corner grocers, 53.

their relation to fixing price on resale, 36 .

\section{HATTERS}

Danbury Hatters' Case, 135.

injunctive relief in similar case, 152. 
INDEXX

\section{[RERERENCES ARE TO SECTIONS]}

HOAR, SENATOR

quoted, 108 n.l.

HOARDING

by large combination, 87.

HOLMES, MR. JUSTICE

dissenting opinion in Dr. Miles Case, 71.

opinion in Northern Securities Case, 118, 139.

opinion in Paine Lumber Co. v. Neal, 152.

HOTELS

case of exchanged, 22 n.46.

ILLUSORY APPOINTMENT

and construction of Sherman Act, 81.

INDUCING BREACH OF CONTRACT, 50.

INDUSTRIAL REVOLUTION, 59, 68.

INJUNCTION (see EQUTTY).

INSURANCE COMPANTES

combination of, 64 n.30.

INTEGRATION OF INDUSTRIES BY EXCLUSIVE CONTRACTS, 28.

INTERLOCKING DIRECTORS

forbidden by Clayton Act, 155.

INTERNATIONAL HARVESTER COMPANY

District Court Decision, 68, 69; quoted, 53 n.18, 70 n.47.

never used excluding practices, 88 .

suppose it refused to deal with independents, 103.

INTERSTATE COMMERCE

Sherman Act a regulation of, 118 n.18.

INTERSTATE COMMERCE COMMISSION

creates competition by ordering interconnections, 119.

INTIMIDATION, 50.

JOINT TRAFFIC ASSOCIATION CASE, 118.120. 


\section{[RERTRENCES ARI TO GECTIONS]}

KALES, A. M.

"Cases on Contracts and Combinations in Restraint of Trade," p. iv, 1 n.1.

"Due Process, the Inarticulate Major Premise and the Adamson Act," 145 n.5.

\section{LABOR UNIONS}

boycott by

at common law, 87.

under Clayton Act, 160, 161.

under Sherman Act, 135, 152.

closed shop used by, 83, 98, 99.

effect of their preponderant position in market, 98.

eliminate competition, 72.

excluding practices by, 98 .

exemplify tendency toward combination, 59.

jurisdictional dispute of, 96, 105.

legal unless they employ excluding practices, 72, 83.

local contrasted with national, 99.

picketing by, 100.

size not illegal unless excluding practices used, 83.

strike by (see STRIKx).

threat to striko-legal or illegal, $96,97$.

under Clayton Act, 157-161.

under Bherman Act, 72.

\section{LAWYERS}

sale of business by, 13.

combinations of, 53.

\section{LEADERS}

met by contracts to fix price on resale, 31-40, 104, 106.

\section{LIBEL}

a form of unlawful competition, 50.

\section{LICENSE}

of patented article with contract to use unpatented accessories, $41-47 \mathrm{~b}$.

LIQUOR BUSINESS

contracts not to engage in, 1.

\section{LIVE STOCK EXCHANGE}

competitive methods used by, 130.

LOCAL PRICE-CUTTING (see Price-CuttTng, LOOAL). 
[REFERENCES ARI TO SECTIONS]

LUMBER DEALERS

competitive methods used by, 132.

\section{LURTON, MR. JUSTICE}

quoted, 134 n.48.

MAIL ORDER HOUSE

picketing a, 100.

\section{MERGER}

Holmes, J., attempts to distinguish from combination by contract, 139.

MIMEOGRAPH CASES (Henry v. A. B. Dick Co.), 41-47b.

\section{MINES}

combined with manufacturing plant, 28.

\section{MONKEY-WRENCH}

judicial misuse of, 38 .

\section{MONOPOLY}

common law meaning of, 50 .

localized, 100.

under Clayton Act, 161.

tendency toward by combination of insignificant units, 55 .

\section{MULE}

contract to force use of specified currycombs on, 44, 116.

\section{NATURAL RESOURCES}

combination of units controlling, 52.

control of by large unit, 85 .

granite quarries, 102.

\section{NECESSARIES}

combination of units controlling, 52 .

\section{NEWSPAPERS}

combination of, 107.

NORTHERN SECURITIES CASE, 118.

dicta by the judges, 139.

followed in U. S. v. Reading Co., 122. 
[BETERENCES ARE TO SEOTONS]

OIJ BUSINESS

combination in (see STANDLRD OK CO.).

OVERPRODUCTION.

evils of, 67.

\section{PAINTINGS}

contracts to force use of certain preservative on, $44,116$.

PARTNERS' CONTRACTS NOT TO COMPETE, 18.

\section{PATENTS AND COPYRIGHTS}

effect of, in general, 162a-172.

Bell Telephone patents, 40.

combinations based on, 167-172.

combinations based on fundamental patents, 172.

contracts to force use of unpatented accessories, 41-47b.

Copyright Act quoted, 162a.

fundamental patents, 40, 172.

in relation to contracts fixing price on resale, 40 .

licenses accompanied by restriction, 164-166.

Patent Act quoted, 102a.

under Sherman Act, 116.

use of patented article by public utility, 165 .

PECKHAM, MR. JUSTICE

opinion in Montague v. Lowry, 131 n.42.

opinion in Northern Securities Case, 139.

opinion in Trans-Missouri Freight Association Case, 138.

PEPPERMINT OIL CASE, 20 n.44.

PERPETUITIES, RULE AGAINST

compared with restraint of trade, 91 .

\section{PHARMACIES}

combination by, 104, 106.

their relation to firing price on resale, 36 .

PICKETING, 100.

PITNEY, MR. JUSTICE

dissenting opinion in Paine Lumber Co. v. Neal, 152, 160 n.11.

\section{PLUMBERS}

competition among, 103. 


\section{INDEX}

[REFERENCES ARE TO SECTIONS]

POWER OF APPOINTMENT

illusory appointment and construction of Sherman Act, 81.

\section{PREPONDERANT POSITION IN THE MARKET}

as a test of a trust, 48 .

businesses which do not occupy, are legal, 53.

effect of, 63 et seq.

in relation to contracts fixing resale price, 39 .

in relation to exclusive contracts of sale and purchase, 27-29.

in relation to labor unions, 98 .

\section{PRESERVATIVE}

contract to force use of on painting sold, 44, 116.

\section{PRICE-CUTTING}

local

explained, 50.

forbidden by Clayton Act, 156.

justified, 94.

met by contracts to fix price on resale, 31-40, 106, see 104.

universal, 77, 86.

\section{PRICE-FIXING}

illegal, 70.

on resale (see Contracts to Fix Resale Price).

shows control of market, 124.

\section{PRICES}

exorbitant, 79, 86.

Brandeis' views on, 79.

fair, 85.

PUBLIC SERVICE COMPANIES (see PUBLIo UTHITIES).

\section{PÜBLIC UTILITIES}

combinations of, 51.

under Sherman Act, 117-122.

field not free, 68 .

use of patented articles by, 165 .

see RAILROAdS.

see Thlephone Companies.

\section{PULLMAN COMPANY}

exclusive contracts with, 27,30 .

QUARRIES, COMBINATION OF, 102. 


\section{[RETIRENCES ARE TO SECTIONS]}

\section{RAILROADS}

combination of, 51, 68 .

contracts with sleeping car companies, 27, 30.

under Sherman Act, 117-122.

\section{REBATES}

a form of unlawful competition, 50 .

in Swift Case, 124.

REFRAINING FROM DOING BUSINESS, 1-25.

\section{RESTRAINT ON ALIENATION}

contract to fix price on resale, 33-35.

contract to force use of accessories, 43.

also see $47 \mathrm{a}, 47 \mathrm{~b}$.

RESTRICTIONS (see Contracts Not to CoMpete).

RESTRICTIVE COVENANTS (see Contracts Not to COMPETE).

\section{RULE AGAINST PERPETUITIES}

compared with restraint of trade, 91.

SALE OF A BUSINESS (see Contracts Not to Compete).

\section{SECONDARY BOYCOTT (see BOYCOTT).}

\section{SECRET PROCESS}

in relation to contracts not to compete, $11 \mathrm{n} .21$.

SERVITUDES, EQUITABLE (see EqUITY).

\section{SHERMAN ACT}

see Table of Contents, chaps. VII-XI.

boycott under, 135, 152.

competitive methods under, 130-136.

constitutionality of, 145-148.

delegation of legislative power, 147, 148.

dne process of law, 145-148.

construction of, 108-112, 145-148.

as influenced by its penal features, 80 .

continuing acts under, 125.

contracts accompanying salo of a business under, 113-114.

contracts to fix resale price under, 116.

exclusive contracts of sale and purchase under, 115. 
[RETERENCES ARE TO SECTIONS]

SHERMAN ACT-Continued.

labor unions under, 72 (also see LABOR UNIONS).

quoted, 108.

stockholder's suit under, 149-152.

suit for triple damages under, 148-153.

who may invoke, 149-153.

SHERMAN, SENATOR

quoted, 68 n.44, 76 n.60.

SHIPPING (see STEAMSHIP CoMPaNIES).

SIZE OF BUSTNESS

as test of illegality, 75 .

\section{SLEEPING CAR COMPANIES}

exclusive contracts with, 27,30 .

SNOW, CONRAD E.

on the Clayton Act, 157 n.5.

\section{SPECIALTY}

fixing price of on resale, 31-40.

SPECIFIC PERFORMANCE (see EQUITY).

STANDARD OF REASON, 145-148.

\section{STANDARD OIL COMPANY}

Standard Oil Trust, 48 n.3, 67, 127.

Standard Oil Company of New Jersey, 48 n.4, 127.

control of pipe lines by, 126 n.34.

if it refused to deal with independents, 103.

prompt service used temporarily by, 107.

Standard Oil Case

analyzed, 65, 126-128.

adopts excluding practices as test, 65 .

affirms traffic association cases, 120.

dictum by judges in, 140.

followed in U. S. v. Reading Co., 122.

rule of reason in, 140.

Standard Oil Company of Ohio Case, 48 n.3, 67.

\section{STEAMSHIP COMPANIES}

combination of, 94 .

under Sherman Act, 136. 
[BETERENCES ARE TO SECTIONS]

STEAMSHIP COMPANIES-Continued.

combination with wharves company and railroad company, 129.

fighting ships, 136.

restrictive covenants concerning, 20.

STEVENS, WILLIAM 8.

article by, 50 n.13.

STOCKHOLDER'S SUIT

to invoke Sherman Act, 149-152.

\section{STRIKE}

compared with blacklist as trade method, 132-134.

compared with boycott, 107.

compared with retailer's boycott, 101.

in jurisdictional disputes, 105.

threat to strike, $96,97$.

under Clayton Act, 160, 161.

used by retailers' association against wholesalers, 104.

TAFT, WILLIAM $H$.

opinion in Addyston Pipe Case discussed, 66.

\section{TARTAR BUSINESS}

rock and bone, 17 .

\section{TELEPHONE COMPANIES}

Bell patents, 40.

combination based on patents like, 172 .

subject to police power of state, 163 .

restrictions accompanying license of, 165.

combination based on fundamental patents, 169-172.

exclusive contracts with, 30 .

illegality of as defense, 153 n.11.

patents of, $40,163,165,169-172$.

relative skill of engineers of, 78 .

restrictions accompanying license of Bell patents.

\section{TERMINAL FACILITIES}

combination of, 121.

THELLUSSON ACT

compared with law of restraint of trade, 91.

\section{TILE DEALERS}

methods used by, 131. 
INDEX

[REFERENCES ARE TO SACTIONS]

TOBACCO CASE (see AMrrican Tobacco Co.).

TORTS

see Competitive Methods.

\& tort defined, 93 .

TRADE COMMISSION LAW, 154.

TRADE UNIONS (see LABOR UNIONS).

TRAFFIC ASSOCTATION CASES (U. S. v. Joint Traffic Association and

U. S. v. Trans-Missouri Freight Association). compared with Northern Securities Case, 139. explained in Standard Oil Case, 143.

TRANS-MISSOURI FREIGHT ASSOCIATION CASE, 117-120. effect of dictum in, 145 et seq. quoted, 113 n.2, 138 n.2.

TRANSPORTATION UNITS (see RAILROADS).

TYING CONTRACTS, 26-30, 115, 156.

UNFAIR COMPETITION see Compettitue Methods. defined, 50.

UNFAIR METHODS OF COMPETITION see Competitive Methods. defined, 50 .

UNION PACIFIO CASE, 119.

UNIONS (see LABOR UNIONS).

UNITED STATES STEEL CORPORATION abandons excluding practices, 88. Brandeis' testimony as to, 75. Government's brief against, quoted, 48.

UNLAWFUL COMPETITION see Competitive Methods. defined, 50 .

UNREASONABLE PRICE, 58. 


\section{INDEX}

[RETRRENCES ARE TO SECTIONS]

UPPER BERTH CASE, 145.

WALL PAPER CASE, 153.

WATCH CASE CASE, 88.

WESTERN UNION TELEGRAPH COMPANY relations with Bell Telephone Company, 165.

WHITE, CHIEF JUSTICE opinion in Standard Oil Case, 126.

WYMAN

"Control of the Market," 50 n.10. 

1:

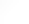





$$
\text { - }
$$







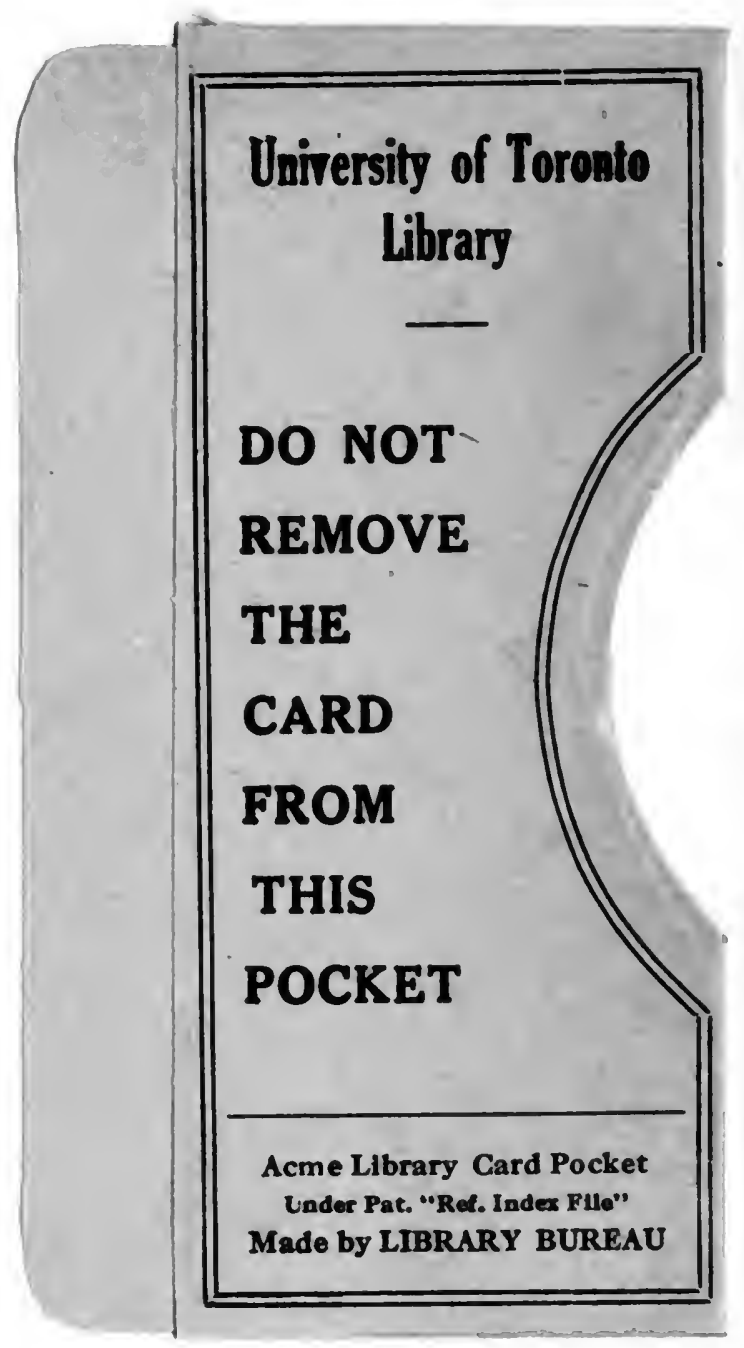


